\title{
A STUDY OF COMMERCIAL GENTRIFICATION AND THE DISPLACEMENT OF SMALL BUSINESSES IN THE DOWNTOWN YONGE STREET NEIGHBOURHOOD
}

\author{
by
}

\author{
Anna Flood \\ BA, Carleton University, 2014 \\ A Major Research Paper \\ presented to Ryerson University \\ in partial fulfillment of the requirements for the degree of \\ Master of Planning \\ in \\ Urban Development
}

Toronto, Ontario, Canada, 2018

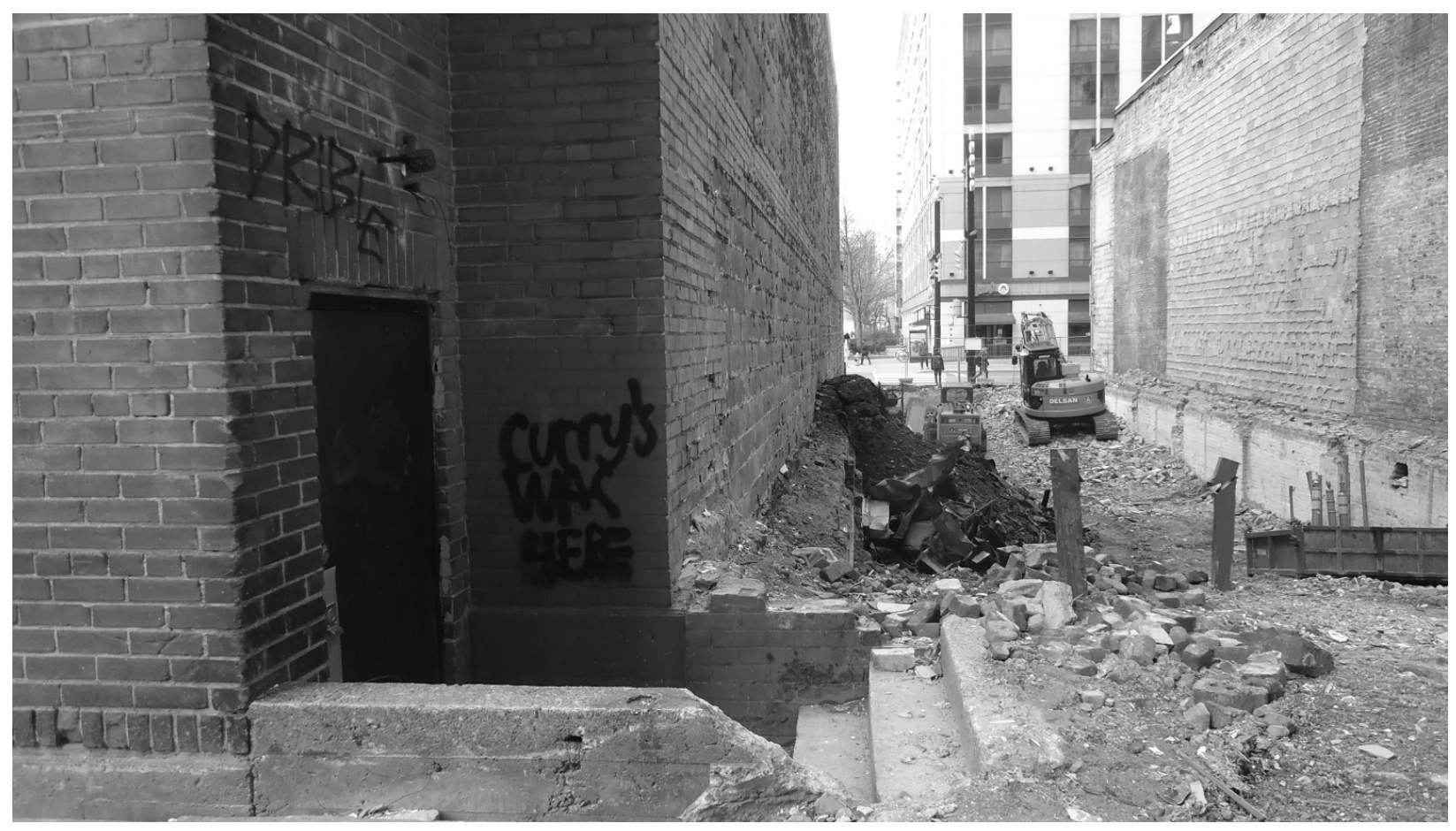

(c) Anna Flood, 2018 


\section{Author's Declaration for Electronic Submission of MRP}

I hereby declare that I am the sole author of this MRP. This is a true copy of the MRP, including any required final revisions.

I authorize Ryerson University to lend this MRP to other institutions or individuals for the purpose of scholarly research.

I further authorize Ryerson University to reproduce this MRP by photocopying or by other means, in total or in part, at the request of other institutions or individuals for the purpose of scholarly research.

I understand that my MRP may be made electronically available to the public. 


\title{
A STUDY OF COMMERCIAL GENTRIFICATION AND THE DISPLACEMENT OF SMALL BUSINESSES IN THE DOWNTOWN YONGE STREET NEIGHBOURHOOD
}

\author{
(C) Anna Flood, 2018 \\ Master of Planning \\ in \\ Urban Development \\ Ryerson University
}

\begin{abstract}
This research explores the unintended consequences of recent development trends for small businesses along Yonge Street between Bloor Street and College/Carlton Street in Toronto. By examining development projects between 2007 and 2018, the preference for large retail units at ground level with high-rise residential condominium towers above is evident. Heritage buildings and attributes are being demolished, where allowed, to create the base that supports this type of development. New development projects are increasing property values and taxes, and commercial rents. The lack of appropriately sized and priced retail space is displacing successful small businesses. The residents who are new to the neighbourhood are increasingly young persons who have higher incomes and levels of educational attainment. Small businesses may be unable to adapt to their consumer preferences. Key opportunities are identified for the City of Toronto to support successful small businesses in the neighbourhood and to maintain the character and heritage of Downtown Yonge Street.
\end{abstract}

Key words: planning; commercial gentrification; displacement; small businesses; Toronto 


\section{Acknowledgments}

I wrote this paper with the guidance and support of my professor and supervisor, Dr. Ronald Keeble. My second reader, Steven Ziegler, provided invaluable insight and encouragement.

Thank you to my sister, Kristen Flood, for your uninterrupted advice about the world of urban planning and to my mother, Susan Webber, for your continuous encouragement. 


\section{Table of Contents}

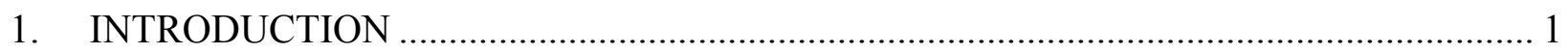

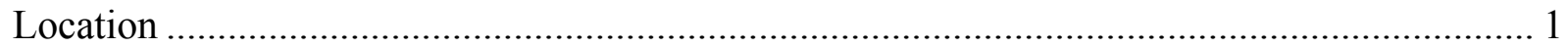

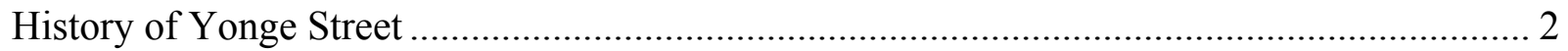

Current State of Downtown Yonge Street ........................................................................... 4

Municipal Responses to Gentrification............................................................................. 6

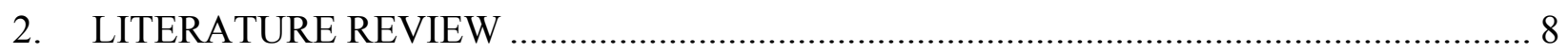

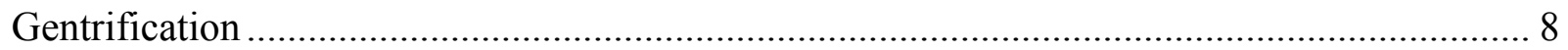

Displacement of Small Businesses .................................................................................... 9

Importance of Small Businesses to Neighbourhood Character ................................................. 14

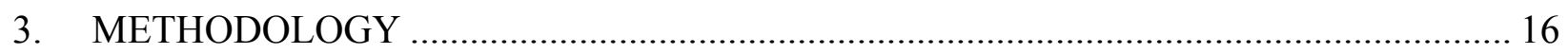

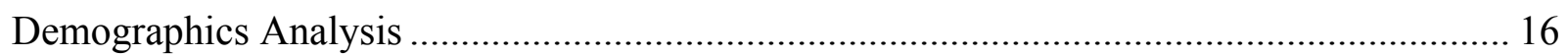

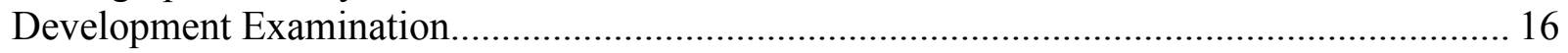

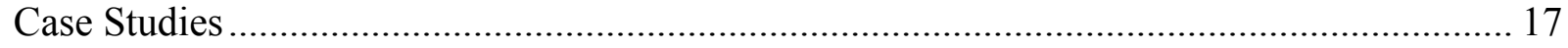

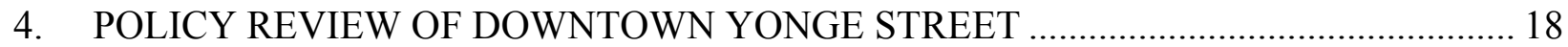

City of Toronto Official Plan (2006) …………………….............................................. 18

City of Toronto Zoning By-law 438-1986 and City of Toronto Zoning By-law 569-2013 .... 19

5. DEMOGRAPHIC ANALYSIS OF DOWNTOWN YONGE STREET ……...................... 21

Population Growth and Density....................................................................................... 21

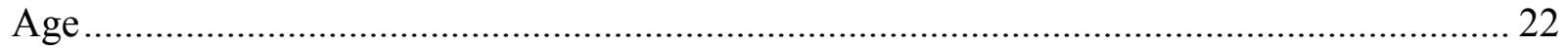

Household Type and Median Income …………………................................................ 22

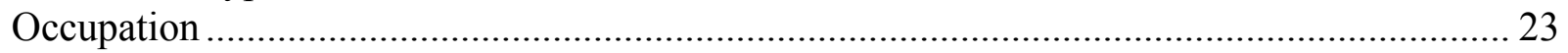

Educational Attainment ………………………………................................................... 23

6. DEVELOPMENT APPLICATIONS FOR DOWNTOWN YONGE STREET .................... 25

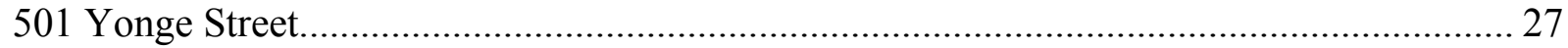

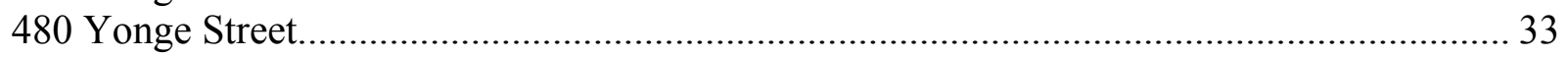

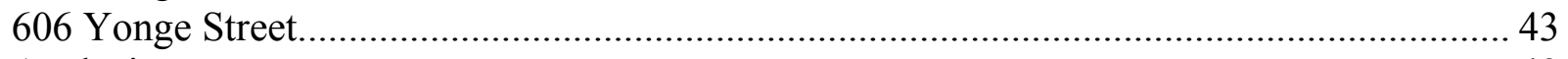

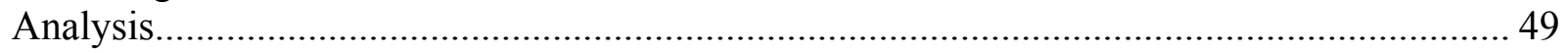

7. CITY OF TORONTO RESPONSES TO COMMERCIAL GENTRIFICATION IN

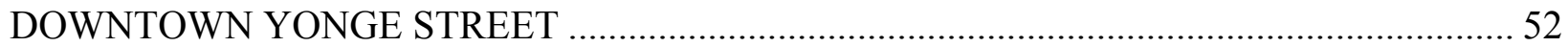

Ontario Heritage Act (1990) ……………………………………………………..... 52

City of Toronto Historic Yonge Street Heritage Conservation District Plan (2016)................ 52

City of Toronto Tall Building Design Guidelines (2013)...................................................... 53

North Downtown Yonge Area Specific Policy No. 382 and Urban Design Guidelines (2013)53

Property Tax Amendments ............................................................................................ 54

8. CASE STUDIES: MUNICIPALITIES' RESPONSES TO COMMERCIAL

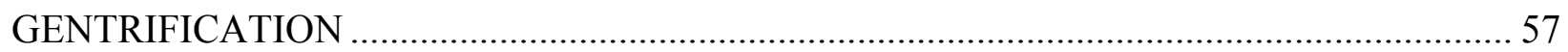

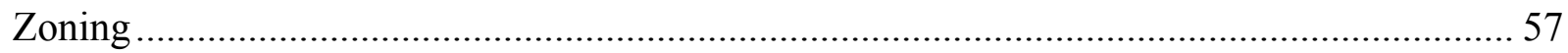

Community Benefits of Agreements ……………………............................................... 59

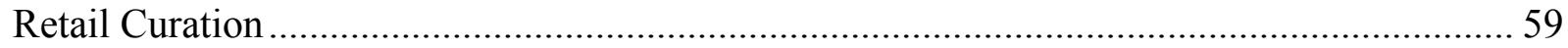




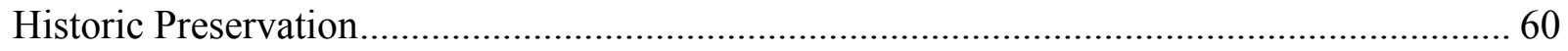

Create a Preference for Local Businesses in Publicly-Owned Buildings, and Vacant and

Under-Utilized Buildings

Provide Affordable Commercial Space through Mission-Driven Entities ................................ 62

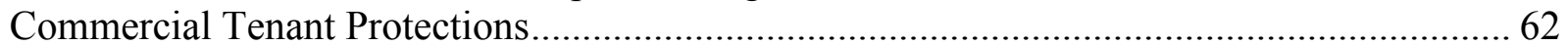

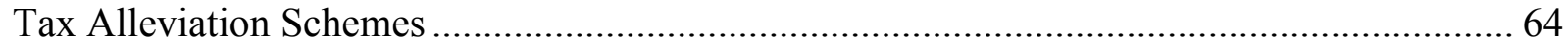

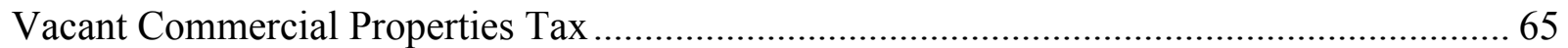

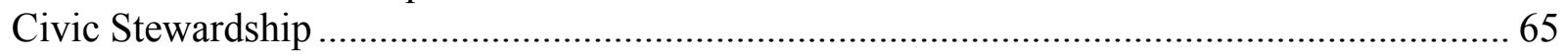

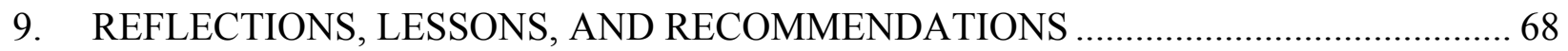

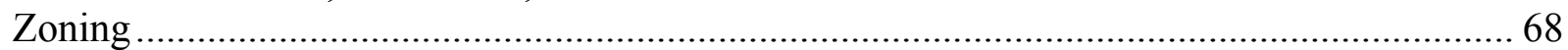

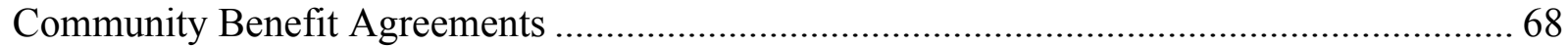

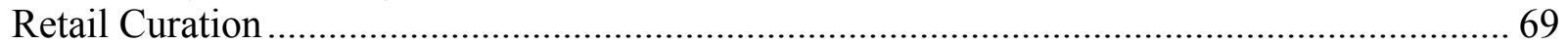

Historic Preservation.......................................................................................................... 69

Create a Preference for Local Businesses in Publicly-Owned Buildings, and Vacant and

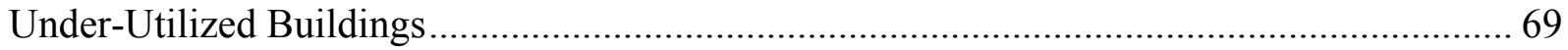

Provide Affordable Commercial Space through Mission-Driven Entities ................................ 70

Commercial Tenant Protections...................................................................................... 71

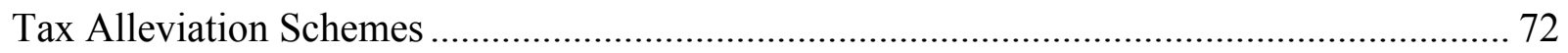

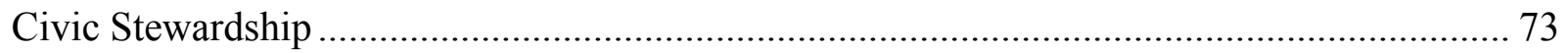

Adjacent Policies ……………………………………………………………………... 74

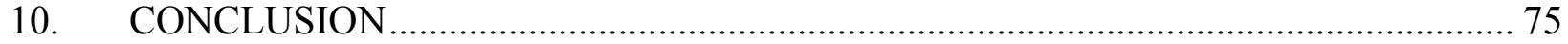

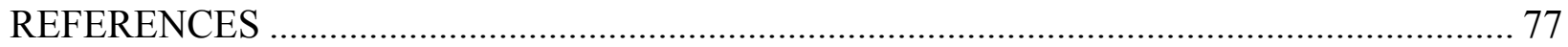




\section{List of Tables}

TABLE 1. USES PERMITTED UNDER THE COMMERCIAL RESIDENTIAL ZONE OF

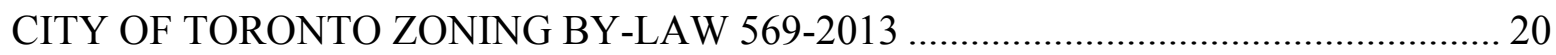

TABLE 2. LOT SIZE AND HERITAGE AT 501 YONGE STREET ........................................... 27

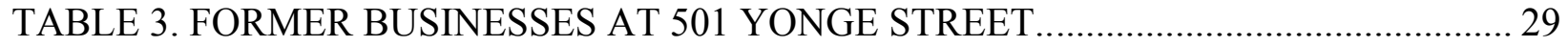

TABLE 4. THE DEVELOPMENT APPLICATION AT 501 YONGE STREET ……................. 31

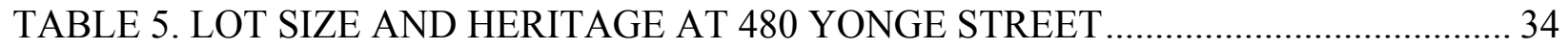

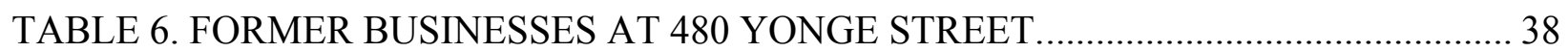

TABLE 7. THE DEVELOPMENT APPLICATION AT 480 YONGE STREET ........................ 40

TABLE 8. LOT SIZE AND HERITAGE AT 606 YONGE STREET ............................................4 44

TABLE 9. FORMER BUSINESSES AT 606 YONGE STREET .............................................. 45

TABLE 10. THE DEVELOPMENT APPLICATION AT 606 YONGE STREET...................... 47 


\section{List of Figures}

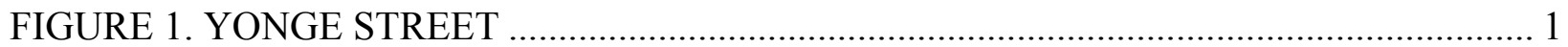

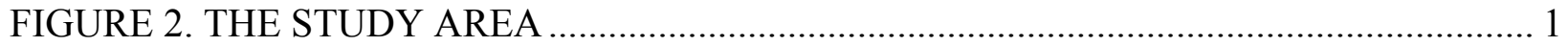

FIGURE 3. TIMELINE OF YONGE STREET'S HISTORY ………....................................... 2

FIGURE 4. DEVELOPMENT APPLICATIONS WITHIN THE STUDY AREA …................... 4

FIGURE 5. BOUNDARIES OF THE CENSUS DATA ……................................................ 16

FIGURE 6. CITY OF TORONTO OFFICIAL PLAN, URBAN STRUCTURE: MAP 2, 2015. 18

FIGURE 7. CITY OF TORONTO OFFICIAL PLAN, LAND USE PLAN: MAP 18, 2015..... 19

FIGURE 6. AVERAGE MEDIAN INCOMES OF RESIDENTS IN DOWNTOWN YONGE

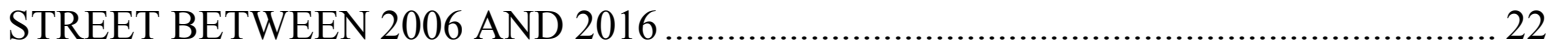

FIGURE 7. LEVELS OF EDUCATIONAL ATTAINMENT OF RESIDENTS IN

DOWNTOWN YONGE STREET BETWEEN 2006 AND 2016 ...................................... 23

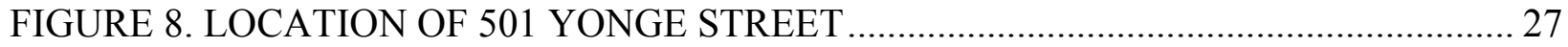

FIGURE 11. COLLINGS TIRE SHOP AT 501 YONGE STREET IN 1929............................. 28

FIGURE 12. SUBWAY CONSTRUCTION LOOKING SOUTH FROM ALEXANDER STREET AT 501 YONGE STREET IN 1951 ……….................................................. 28

FIGURE 13. 501 YONGE STREET PRIOR TO REDEVELOPMENT IN SEPTEMBER 201530 FIGURE 14. 501 YONGE STREET DURING REDEVELOPMENT IN APRIL 2018 ............. 31 FIGURE 13. LOCATION OF 480 YONGE STREET ………………………………......... 34 FIGURE 16. 480 YONGE STREET PRIOR TO REDEVELOPMENT IN AUGUST 2017 ....... 34 FIGURE 14. 492-494 YONGE STREET AND 3 GROSVENOR STREET LOOKING SOUTH

ON GROSVENOR STREET PRIOR TO DEMOLITION IN APRIL 2018 ………............ 35

FIGURE 15. ST. CHARLES TAVERN AT 480 YONGE STREET IN OCTOBER $1961 \ldots . . . . . .36$

FIGURE 14. 490 YONGE STREET FOLLOWING DEMOLITION IN APRI1 2018 …............ 37

FIGURE 20. 480 YONGE STREET DURING REDEVELOPMENT IN APRIL 2018 ............. 40

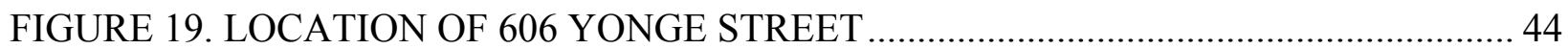

FIGURE 22. 606 YONGE STREET PRIOR TO REDEVELOPMENT IN JULY 2009............. 46

FIGURE 23. 606 YONGE STREET FOLLOWING REDEVELOPMENT IN APRIL 2018 ..... 48 


\section{INTRODUCTION}

\section{Location}

Yonge Street is a major arterial road in the City of Toronto. Extending 1,896 kilometres in length and connecting Lake Ontario to Lake Simcoe, it is the longest street in North America (see Figure 1) (City of Toronto, 2013a). The area of Yonge Street, which will be studied, is in the downtown core of Toronto between Bloor Street to the north and College/Carlton Street to the south. It encompasses the surrounding area of Yonge Street between Bay Street to the west and Church Street to the east (see Figure 2). These boundaries are the same as the ones for the Historic Yonge Street Heritage Conservation District Plan (City of Toronto, 2016a). They are also similar to the ones for the North Downtown Yonge Street Site and Area Specific Policy No. 382 and Official Plan Amendment No. 183. Herein, this area will be referred to as either the "Study Area" or "Downtown Yonge Street".

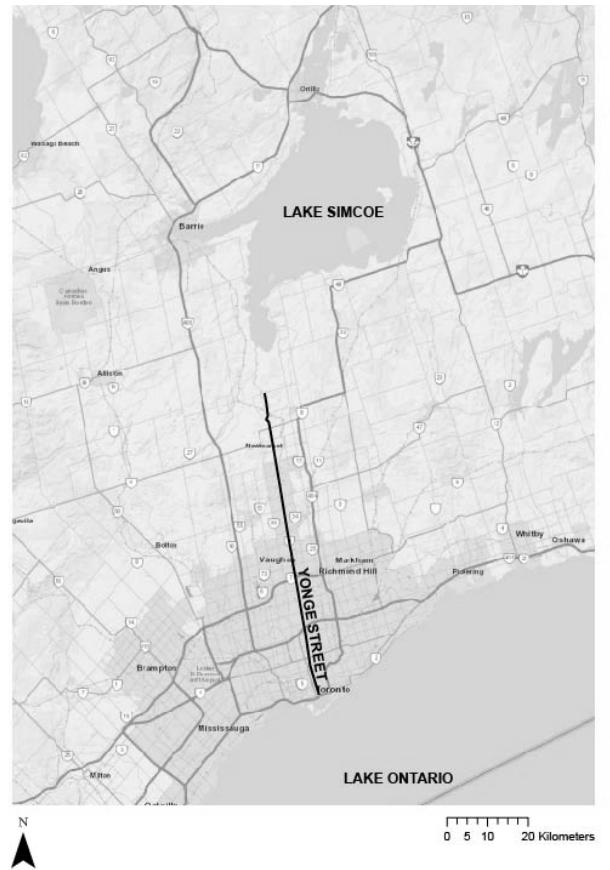

Figure 1. Yonge Street. (Source: Anna Flood)

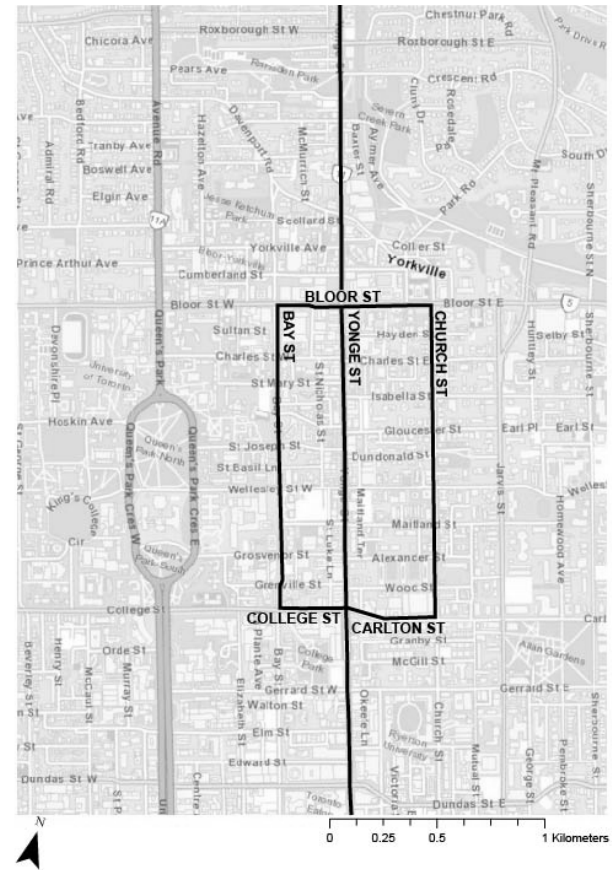

Figure 2. The Study Area. (Source: Anna Flood). 
Downtown Yonge Street is a vibrant neighbourhood which is characterized by its mix of uses, scales o built form, and narrow retail frontages. The neighbourhood has several heritage properties and resources, and notable landmarks. As a major north-south corridor, Downtown Yonge Street provides access to neighbourin£ collector and local streets (City of Toronto, 2013a). The majority of commercial uses front directly onto Yong Street. However, residential uses also affect small businesses on Yonge Street. They mostly occupy the surrounding area bound by Bay Street to the west and Church Street to the east. Downtown Yonge Street will be the focus of this study, but it will also be important to consider the context in order to make appropriate recommendations for the neighbourhood.

\section{History of Yonge Street}

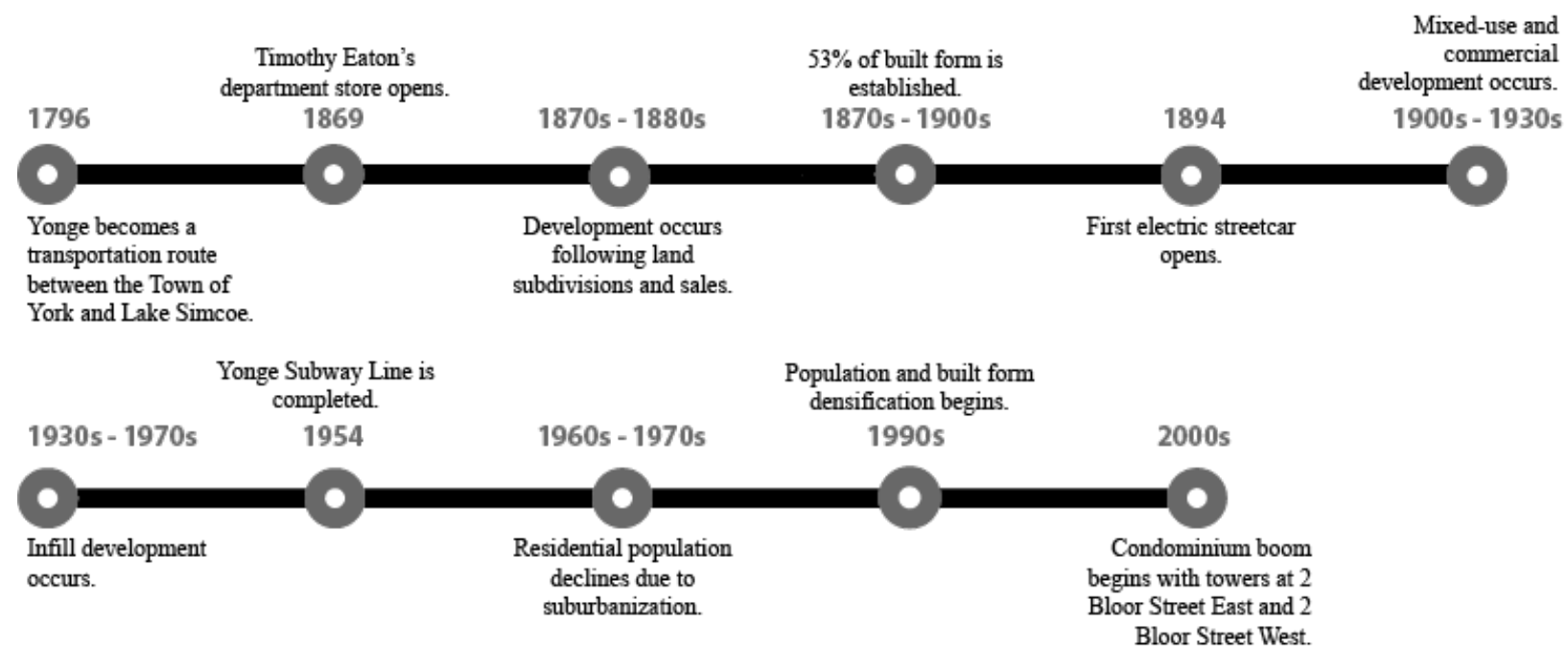

Figure 3. Timeline of Yonge Street's History, (Source: Anna Flood).

Yonge Street is a main commercial street in Toronto with an important history. It established itself as the city's principal north-south street when it became a transportation route between the Town of York and Lake Simcoe in 1796. Development was slow because most of the land was privately-owned. After the land was subdivided and sold, it was not more densely developed until the 1870s and 1880s (City of Toronto, 2016a). The opening of Timothy Eaton's department store established Yonge Street as a major shopping street in 1869. Rapid 
development occurred between 1870 and 1900 when $53 \%$ of the built form was established. The first electric streetcar took the place of the diesel buses serving residents in 1894 (City of Toronto, 2013a). Mixed-use buildings and commercial buildings fronting along Yonge Street followed from 1900 to 1930 . Butcher shops, grocery stores and confectionaries were repurposed to automobile showrooms and service facilities in these commercial buildings. $79 \%$ of buildings were built prior to 1930 so infill development transpired between 1930 and 1970. Noncommercial buildings were converted to other uses and the electric streetcar was replaced by Toronto's first subway line which was completed in March 1954. The population experienced a decline with suburbanization in the 1960s and 1970s. To attract an urban population, streetscape improvements, open space expansions and retail events happened concurrently during this period. Intensification did not begin until around the 1990s (City of Toronto, 2016a).

The condominium boom has recently emerged with the first two high-rises at 2 Bloor Street West and 2 Bloor Street East (City of Toronto, 2016a). Today, Yonge Street is characterized by low-rise buildings with a street wall height of two to four storeys, and retail frontages of about five metres in width situated on shallow lots ranging from 18 to 25 to 30 metres in depth (City of Toronto, 2013a). There are several buildings which have been designated or listed through the City of Toronto Heritage Inventory in the Study Area (City of Toronto, 2016a).

Yonge Street continues to be a significant place for people to gather and celebrate. One of the first parades was the Santa Clause Parade along Yonge Street. Other popular parades include the Gay Pride Parade, the Dyke March, the Trans March, the Festival of India Parade, and the St. Patrick's Day Parade. Yonge Street is connected to Toronto's Gay-Lesbian-Bi-TranssexualQueer (GLBTQ) community with early GLBTQ-friendly spaces, such as the St. Charles Tavern 
and Stages Nightclub. The St. Charles Tavern was located at 480-484 Yonge Street, a site which has been recently selected for redevelopment and will be studied in Chapter 6. It was known as the host to a popular Drag Queen ball on Halloween nights. Yonge Street is also associated with the counterculture movement from the 1960s due to its proximity to Toronto's Yorkville neighbourhood whose music venues and coffeehouses were important to the youth-driven movement (City of Toronto, 2016a).

\section{Current State of Downtown Yonge Street}

Downtown Yonge Street has

experienced dramatic growth during the past decade. Like many of Toronto’s neighbourhoods, Downtown Yonge Street continues to face serious development pressure. Cranes and scaffolding have almost become a part of the streetscape experience as infill and new development projects proliferate. Seven of the 10 blocks within the Study Area are a development site or will be a future development site where another

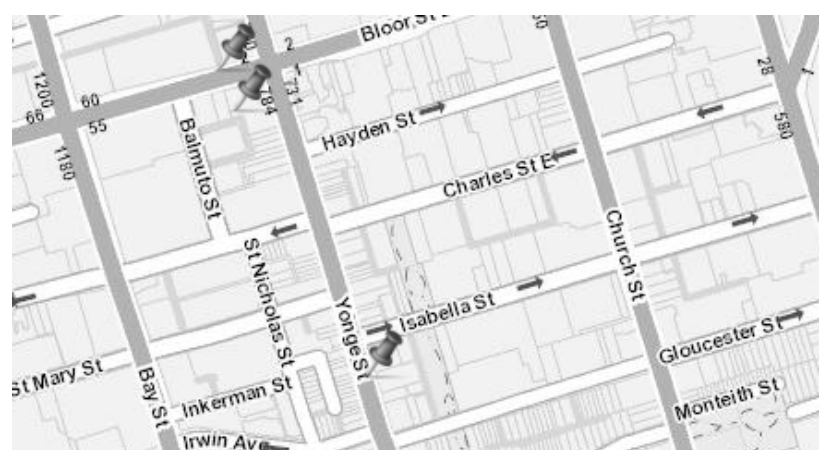

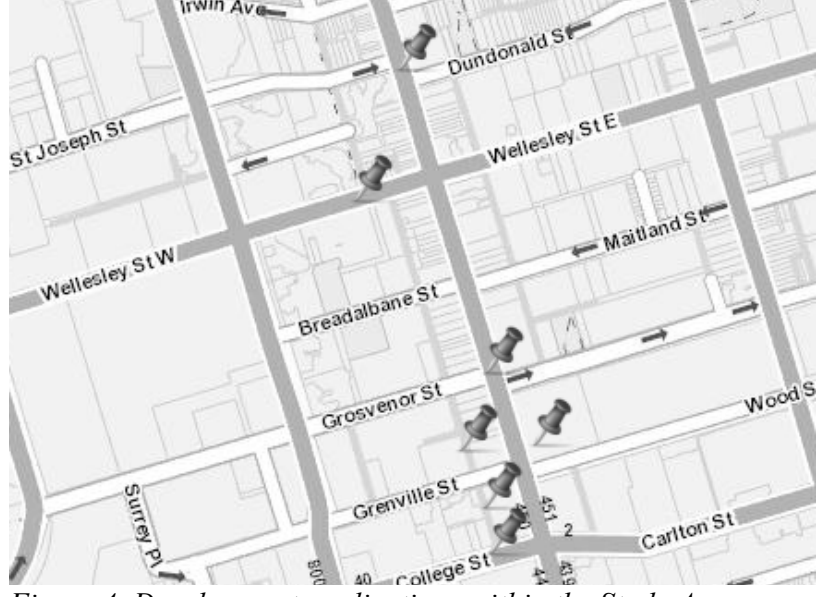

Figure 4. Development applications within the Study Area. (Source: City of Toronto, 1998-2018a)

condominium building is shooting into the sky. Occupying the ground floor of new and existing buildings, businesses are popping up to satisfy the evolving tastes of new residents and visitors. "Mom and pop" style businesses are being replaced by chains ranging from a Taiwanese fried chicken international chain restaurant (Hot Star Large Fried Chicken at 374 Yonge Street) to a large Korean supermarket chain (Galleria Supermarket at 558 Yonge Street) to a local fresh 
pressed juice store (Daily Press Juicery at 605 Yonge Street). These novel commercial enterprises have arisen due to changing built form, emerging consumer preferences and steep rises in commercial property values, taxes and rents.

New residents with higher incomes and higher levels of educational attainment are moving into the neighbourhood. They are increasing property values and taxes. Spikes in property taxes are being translated into rises in commercial rents thus financially threatening the existence of small businesses. Small businesses are also being physically displaced by developers who are acquiring adjacent existing buildings. Walls of previous retail units and entire former retail spaces are being demolished to create larger retail units. New businesses are occupying these retail units and catering to the consumer preferences of new residents. The introduction of new residents and the businesses that appeal to their consumer preferences has led to the loss of small businesses that infused the neighbourhood with character. The quirky plethora of small businesses, which initially attracted new residents and visitors to the neighbourhood, are disappearing. Chains and vacant storefronts are taking their place.

Throughout this paper, small businesses and chains will be defined according to Sharon Zukin (2009)'s definitions in New Retail Capital and Neighbourhood: Boutiques and Gentrification in New York City. Small or local businesses are defined as “... individually owned small businesses that served long-term residents prior to recent redevelopment..." (p. 58). Chain or corporate businesses are defined as “... publicly traded franchises or large local or trans local chains with considerable market share..." (p. 58). A third category of businesses, new entrepreneurial, will also be explored. New entrepreneurial businesses are defined as “... small local chains or individually owned stores with a recognizably hip, chic or trendy atmosphere offering innovative or value-added products (i.e. designer furniture or clothing, gourmet food 
and enjoying a buzz factor in promotion, including heavy press coverage and online presence" (p. 58).

\section{Municipal Responses to Gentrification}

Given local outcry to maintain the presence of small businesses in Downtown Yonge Street, the City of Toronto has begun to act to reverse the effects of development on the neighbourhood's character and heritage. For the field of urban planning, the most effective tool available is policy. The City of Toronto has introduced policy initiatives with the intent to protect the character and heritage of this area. These include designation as a Heritage Conservation District; enacting Official Plan Amendment No. 352 for tall buildings where setbacks are required to fit within the existing context; and Official Plan Amendment No. 183 and Official Plan Site and Area Specific Policy No. 382 for the character and heritage protection of North Downtown Yonge Street. Stakeholders have engaged with business and property owners to tackle the sudden spike in commercial property taxes in the area. They have assisted owners with successfully appealing and reducing their recent assessments with the Municipal Property Assessment Corporation (MPAC). The City is currently negotiating with the Province to introduce a new class of commercial property taxes that would be more appropriate for local businesses or low-rise buildings.

Although these municipal initiatives represent a response to the problem, additional strategies need to be evaluated as the problem persists. Small businesses continue to close their doors to be replaced by chains and vacant storefronts. Whole buildings and elements of buildings continue to be demolished to make way for new condominium buildings. How can municipalities, such as Toronto, mitigate the loss of small businesses that are otherwise successful outside of the climate created by gentrification pressures? This paper looks to other 
municipalities that are experiencing similar issues to Downtown Yonge Street for their policy and community-building initiatives. 


\section{LITERATURE REVIEW}

To provide a broader context for the situation in which Downtown Yonge Street currently finds itself, this chapter will provide a review of the literature that exists regarding 1)

gentrification; 2) the displacement of small businesses; and 3) the importance of small businesses to neighbourhood character.

\section{Gentrification}

In London: Aspects of Change, Ruth Glass (1964) was the first to describe gentrification when she wrote:

One by one, many of the working class quarters of London have been invaded by the middle classes - upper and lower. Shabby, modest mews and cottages - two rooms up and two down - have been taken over, when their leases have expired, and have become elegant, expensive residences... Once this process of gentrification starts in a district, it goes on rapidly until all or most of the original working class occupiers are displaced, and the whole social character of the district is changed (p. xvii).

More recently, gentrification has been defined as “... a particular type of neighbourhood ascent that includes the reinvestment of capital, displacement of existing residents, the entry of middle- or upper-class residents, and a change in the social, economic, cultural, and physical landscape of preciously disinvested neighbourhoods” (Owens, 2012, p. 345) and “...the transformation of a working-class or vacant area of the central city into middle-class residential and/or commercial use..." (Lees, Slater, \& Wyly, 2008, p. xv).

Gentrification has been characterized by waves which vary in terms of their cultural and economic characteristics. In the first wave of gentrification, urban pioneers move into neighbourhoods that are considered less desirable by middle-income persons. They benefit from neighbourhood attributes, such as location and low rent, which are thought to outweigh drawbacks like crime and disinvestment (Doan \& Higgins, 2001). Urban pioneers are typically young singles or couples without children. Income and occupation are usually indicators of the 
differences between gentrifying and displaced populations. The new residents tend to be better paid and have higher incomes than the long-term residents who are displaced. Educational attainment has also been used as a marker of class, capturing gentrifying populations which may include artists and young professionals with low incomes yet high levels of educational attainment. In the second wave of gentrification middle-class residents have migrated to the neighbourhoods following external corporate investment in the neighbourhoods. Higher-end businesses accompany the new middle-class residents while the long-term residents are displaced (Freeman, 2005).

Gentrification is a contested issue because it has perceived advantages and disadvantages. For those scholars who view gentrification positively, the rationale is generally that new residents who move into a community create demand. In turn, demand creates investment and raises property values. Properties which have declined due to disinvestment will become more attractive with investment, raising property values. Gentrification reinvests in dilapidated communities (Godsil, 2013). Growing property values are correlated with declining crime rates which help to restore these communities (Kiviat, 2008). However, the key disadvantage of gentrification is soaring rent prices which can force people to leave their homes and their businesses (Lees, Slater, \& Wyly, 2008).

\section{Displacement of Small Businesses}

Gentrification is a popular field of urban study. However, scholars have largely focused on gentrification as a housing problem in which long-term residents are forced to relocate to neighbourhoods where the cost of housing is lower. The new residents who move into the neighbourhoods can afford the higher cost of housing. Meanwhile, the impact of gentrification 
on commercial occupants has been overlooked. Scholars have recently begun to study commercial gentrification and the role it plays in social inequity (Deener, 2007).

Commercial gentrification can create economic growth and new consumer purchasing power, thus raising the demand for certain goods. With economic growth and rising property values, landlords may choose to sell or redevelop their properties to capture the spike in real estate prices (Hill \& Pozzo, 2005). The rent gap theory (Smith, 1987) and the consumption side theory (Ley, 1994) both explain the changes that most impact small business owners. The former theory explains that rent gap is the difference between the rental income that a property currently generates and the rental income that the property could potentially generate if that property is at its highest and best use. When the rent gap widens, developers and property owners may choose to reassess the use, leading them to reinvest and redevelop the property for new residents to realize the potential profit. When the rent gap closes, redevelopment has increased the cost of rental property, leasing rates, and mortgages (Smith, 1987).

The real estate market evaluates properties based on the principle of highest and best use. In the wake of gentrification, this principle can threaten the sustainability of small businesses (Sutton, 2010). In hot real estate markets in large cities, high-rise condominium buildings are often considered the highest and best use. Luxury condominium units are favoured over affordable rental units. This assessment tends to increase the value of surrounding properties, consequently raising the property taxes of surrounding properties. Dramatic hikes in property taxes can render a property unaffordable, translating to property owners either selling their properties or imparting the burden onto tenants in the form of rent increases (Lees, Slater \& Wyly, 2008). It can also result in an increasing number of evictions. Affordability becomes an issue and long-term residents are widely seeking a means of preserving affordable housing 
(Newman, 2008). Zukin (2010) argues that the real estate industry uses the notion of authenticity created by notable small businesses to market distinct neighbourhoods. Ultimately, such marketing strategies drive the value of real estate up, and native residents and business owners out. Small businesses receive "...demonization to make way for luxury condominiums." (Williams \& Needham, 2016, p. 2).

The consumption side theory explains that the consumption patterns of people who live in a neighbourhood change with the shifting demographics of new residents (Ley, 1994). When gentrification occurs in a neighbourhood, the demographics of the community change dramatically. With changes in demographics, the consumption and buying patterns of those who live in the community also alter (Lees, Slater, \& Wyly, 2008). The theory hinges on the emergence of a middle class and the new residents' cultural and consumption preferences (Ley, 1994). The influx of new higher-income residents inspires new businesses to open to satisfy their consumer preferences. Gentrification can impact the customer base and operations of small businesses that rely on their historic local patrons, the population that is typically displaced by economic forces within the scope of gentrification (Zukin, 2010).

Unable to adapt and afford the higher rent, these small business owners can be displaced. New businesses that have a higher value and are more competitive move in to take their place. They can also be replaced by more profitable residential conversions or redevelopment (Pratt, 2009). Developers will look for tenants who they believe will capture the demand for new consumer goods or services while being able to pay more in rent based on the expectation that they will generate higher potential revenues. Replacement businesses frequently take the form of international chain stores and franchises (Sutton, 2010). Chain stores can offer lower prices and capture higher profits due to economies of scale (Ritter, 2009). They can diversify their risks 
over other markets, allowing them to lock into longer leases. This lowers the risk for developers. Chain stores are backed by large corporate structures and can feasibly lend credit to developers who are willing to accept debt financing (Miles et al., 2007).

According to Gratz and Mintz (1998), volume-driven lenders have replaced community lenders. They are no longer as flexible when using physical and financial formulas. Volumedriven lenders make loans based on the credit of project tenants rather than the record of the developer. They resist mixed-use loans that finance "apartment-over-the-store developments" that are traditional of downtowns (Gratz \& Mintz, 1998, p. 170). Development lenders analyze the credit of proposed tenants because a development project's ability to generate income depends on the tenant's ability to pay their rent. A property with tenants who have weak credit is riskier than one with tenants who have strong credit. According to Seidman (2005), ideally development lenders should balance concerns about tenants' credit with a mandate to foster the creation of new business and to promote local ownership of businesses. This mission is not achieved if only well-established businesses and chains are considered credit-worthy.

Small businesses are important to the history and character of neighbourhoods. Neighbourhoods that have larger segments of their population from low to moderate-income households tend to seek out cheaper goods because they are impacted by increasing residential rents more quickly and severely (Levy, Comey, \& Padilla, 2006). The arrival of chain stores in areas that have small, independently-owned stores disrupts social bonds. An example used by Zukin (2009) is the choice that residents must make between a corner bodega where the owner offers credit or a supermarket that is well-stocked yet impersonal. Still, residents may no longer have this choice when commercial rents rise and long-term independent stores must leave because they cannot afford the increase. Stores, which are original to the area, may disappear 
after their leases end and be replaced by new luxury condominium buildings. Alternatively, they may be able to adapt to change by upgrading their merchandise and ambiance to attract new customers. But, stores may do so at the risk of losing their long-term customers (Lloyd, 2006). Commercial gentrification can have benefits, such as increased property tax directed to municipal coffers, the opening of new businesses, improvements to the neighbourhood and economic growth (Shiflet, 2006). In the past, these benefits obscured the social problems inherent in gentrification which were not formerly recognized. Through gentrification, small businesses are being displaced. It is now acknowledged that when they are displaced, the sense of community and cultural and historic character weaken with the disruption of the local economy. Although change is inevitable in any neighbourhood or city, and businesses that do not adapt to this change will fail in the private market, fast and exorbitant increases to property values and rents will displace businesses that would have been otherwise successful (Rose, 2001).

Small business owners report feeling disregarded in transformative efforts as they may lack the political and financial resources to have their voices heard. They also do not have a uniform voice without any formal organizations to represent them. It is important that local businesses are engaged in the transformation process because they play a vital role in the character and life of cities (Imrie, Thomas, \& Marshal, 1995). Sutton (2010) argues that “... Irrespective of firm size, unmitigated retail development should not be considered an idealized end signifying vitality and progress. Instead, well-established principles of neighbourhood revitalization that underscore progressive community-based planning, local decision making, and equitable distributive effects are the logical starting point for reclaiming commercial revitalization" (p. 356). 


\section{Importance of Small Businesses to Neighbourhood Character}

Gentrification causes shifts in the economic, social and cultural landscape of communities (Hill \& Pozzo, 2005). Demographic and economic shifts can alter the character of a neighbourhood (Williams \& Needham, 2016). Under the guise of "regeneration", "renewal" or "revitalization" (Wyly \& Hammel, 2005), a neighbourhood can be "destroyed by the duplication of its own greatest successes" (Jacobs, 1961). Gentrification can change the urban fabric or social design of the community wherein the city loses parts of its history, culture, and identity (Harris, 2010). Conventional retail, such as national banks, pharmacy chains and fast-food franchises, homogenize landscapes (Mitchell, 2006). Streets can become unvarying and barren of unique and interesting places to shop, eat and play. Neighbourhoods lose the identity that initially attracted people to them (Lees, Slater \& Wyly, 2008). Small businesses offer unique products whereas chain businesses compromise the diversity and entrepreneurial spirit of neighbourhoods which have historically been defined by the character of their small business retail districts (Hill \& Pozzo, 2005).

Independent and small retailers produce positive economic and social benefits for families, and local and regional communities (Jacobs, 1961, Mitchell, 2006). However, according to Sutton (2010), "In general, the role of merchants is implicitly assumed yet conceptually and empirically underdeveloped regarding neighbourhood revitalization" (p. 353). There is little evidence to support the popular thought that small shops help to maintain and enhance the vitality of local communities. With this understanding, Hastings and Reynolds (n.d.) have conducted research on the topic. In their joint paper, the authors conclude that convenience stores play an important role in the social life of communities where a sense of communality is an aspect that larger supermarkets cannot replicate in the same informal and hands-on way. 
Small shops act as community hubs where residents can congregate and interact with one another. They also have the capacity to customize their products and services to community needs. This research builds upon the idea of third places. Third places are informal public gathering places in consideration of home being the first place and work being the second place where people spend most of their time. These places include candy stores, soda fountains, coffee shops, diners, etc. which are conveniently located and rooted in community life (Oldenburg, 1996-97).

Jane Jacobs (1961) argues that fine grain urbanism is important to the character of neighbourhoods. She also cites the value that retail offers for the feeling of safety in neighbourhoods. Retail gives residents and strangers a reason to use the sidewalks. With more people walking, people are more likely to notice when something is out of the ordinary. This improves the safety of the streets.

Commercial streets support ethnic entrepreneurship in multi-cultural districts rather than ethnic enclaves (Shaw, Bagwell, \& Karmowska, 2004). They are also commonly accepted as a staple of creative urban planning among policy-makers and urban planners (McLean \& Rankin, 2014). 


\section{METHODOLOGY}

\section{Demographics Analysis}

Census data from Census profiles was analyzed from Statistics Canada for the years, 2006 and 2016. This data was taken from Census Tracts that align with the boundaries of Study Area. Although it is not part of the Study Area, the area between Bay Street to the east and Queens Park Crescent West to the west was also included due to the shape of the Census Tracts. In total, three Census Tracts were used for data from 2006 and 26 Census Tracts were used for data from 2016. The following demographics information was analyzed: population size,

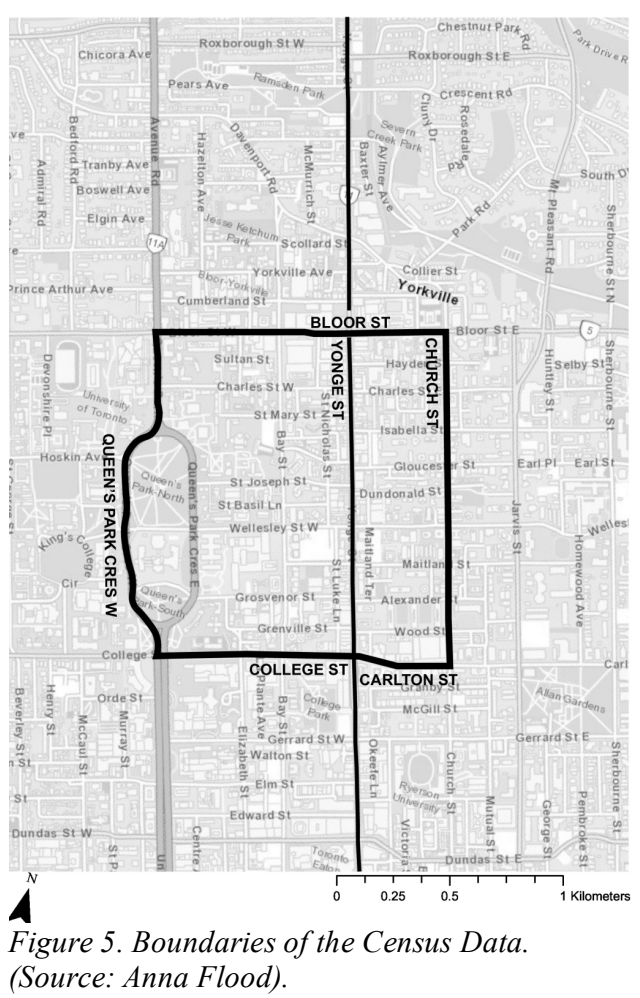
population density, number of immigrants, number of visible minorities, age, household type, median household income, occupation and educational attainment. The purpose of a demographics analysis is to examine the change that has occurred in the population of residents who live in the neighbourhood. A ten-year framework from 2006 to 2016 was chosen to roughly coincide with the timeline for the three development projects at 480 Yonge Street, 501 Yonge Street and 606 Yonge Street occurring between 2007 and 2018. Comparing who lived in the Study Area over a period of ten years should provide insight into the different types of residential and non-residential uses which have varied over the decade.

\section{Development Examination}

Current development applications, nine in total, for Downtown Yonge Street were identified using the Application Information Centre (AIC) on the City of Toronto website. Two 
current development applications and one past development application were reviewed in detail. Two development applications are at the Notice of Application Conditions (NOAC) stage and the third development project has already been completed. A comparison was made of certain elements, including the lot size in square metres, height in storeys, height in metres, total Gross Floor Area (GFA) in square metres, retail GFA in square metres, number of retail units (if applicable), residential GFA in square metres, number of residential units, density, number of parking spots and heritage structures pre-and post-development. The purpose of this comparison was to see how the physical details are changing the character of the area, providing a deeper understanding of how development trends will affect the types of residents and businesses which occupy the area in the future. The businesses which occupied the sites were also inventoried and categorized based on being local, new entrepreneurial or corporate businesses.

\section{Case Studies}

Case studies were reviewed from municipalities other than Toronto. They were chosen based on the municipalities' similarity to Toronto in terms of the challenges they are facing with development and gentrification pressures displacing original residents and small businesses. The municipalities that were studied are all within North America. They are implementing innovative planning and policy mechanisms to help support small businesses. The municipalities were reviewed to help inform recommendations for how the City of Toronto can potentially implement solutions that will help maintain small businesses, and the character and heritage of Downtown Yonge Street. 


\section{POLICY REVIEW OF DOWNTOWN YONGE STREET}

To understand the way in which Downtown Yonge Street has developed and how it will continue to develop, it is important to understand the Study Area within the context of policy.

\section{City of Toronto Official Plan (2006)}

Downtown Yonge Street is located within the Downtown and Central Waterfront boundary according to Map 2: Urban Structure.

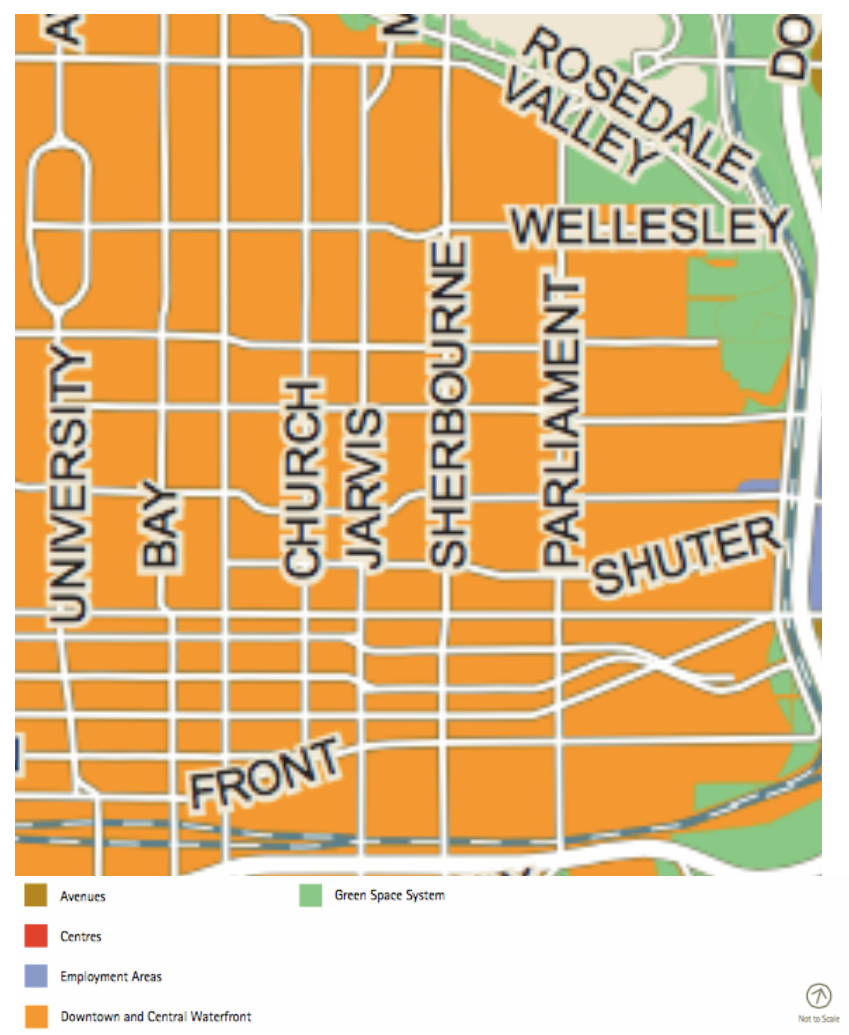

Figure 6. City of Toronto Official Plan, Urban Structure: Map 2, 2015.

It is designated Mixed Use Areas by Map 18: Land Use Plan. A linear park system is designated Parks along the easterly boundary of the area between Charles Street East and Dundonald Street. This linear park system includes George Hislop, Norman Jewison and James Canning Gardens. To the east and west, the area abuts areas designated Apartment Neighbourhoods. 


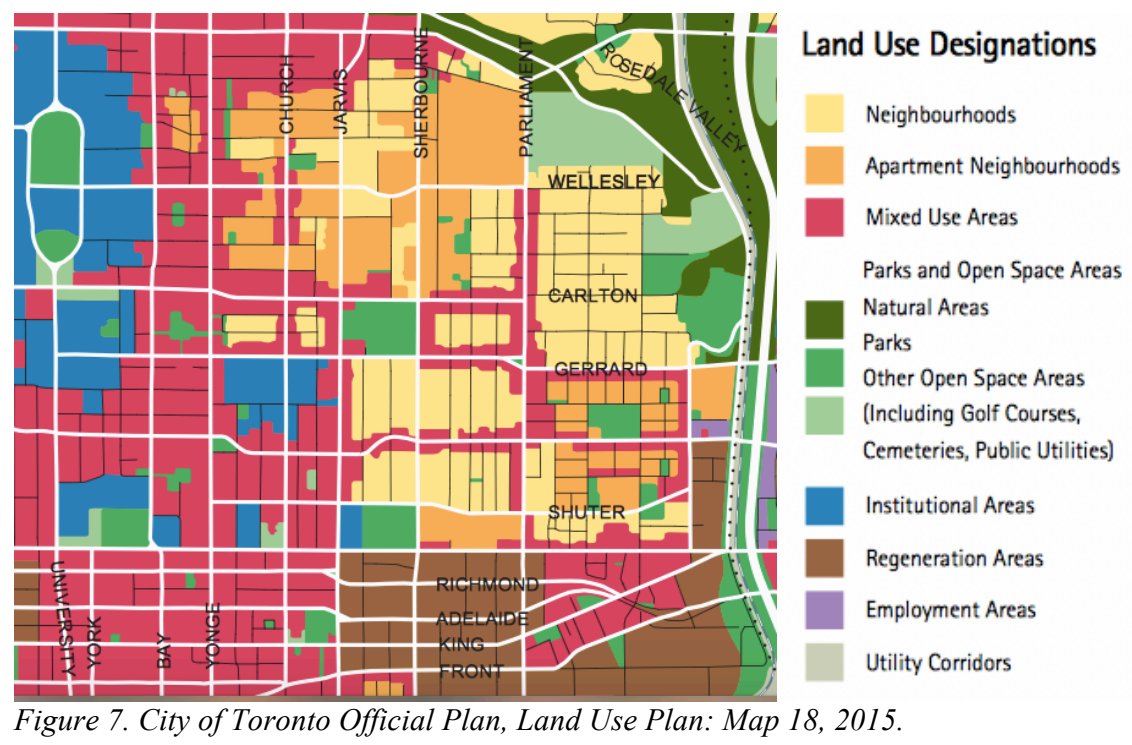

City of Toronto Zoning By-law 438-1986 and City of Toronto Zoning By-law 569-2013

The City of Toronto adopted the City of Toronto Zoning By-law 569-2013 in May 2013. However, the requirements of both the City of Toronto Zoning By-law 569-2013 and 469-1986 will apply until all appeals of the former are resolved.

Generally, the zoning of Downtown Yonge Street is Commercial Residential as per s. 40.10 of Zoning By-law 569-2013 and s. 8 of Zoning by-law 486-1986.

The maximum permitted density ranges depending on the site. Generally, the density is 3.0 times the lot, 2.0 times the lots for commercial uses and 3.0 times the lot for residential uses (CR3.0: C2.0 and R3.0) for those lands which are between Bloor Street and College/Carlton Street. The density is 7.8 times the lot: 4.5 times the lot for commercial uses and 7.8 times the lot for residential uses (CR7.8: C4.5 and R7.8) for those lands which are closer to the major intersections of Bloor Street and College/Carlton Street.

The maximum permitted height also ranges depending on the site. Generally, the maximum permitted height is from 16.0 to 30.0 metres.

The following table presents a list of the uses, both commercial and residential, which are permitted for Commercial Residential zones under Zoning By-law 569-2013. 


\begin{tabular}{|c|c|}
\hline Commercial uses include: & Residential uses include: \\
\hline Ambulance Depot & $\begin{array}{l}\text { Dwelling Unit in a permitted building type in } \\
\text { Clause } 40.10 .20 .40\end{array}$ \\
\hline Art Gallery & Hospice Care Home \\
\hline Artist Studio & Nursing Home \\
\hline Automated Banking Machine & Religious Residence \\
\hline Community Centre & Residential Care Home \\
\hline Courts of Law & Respite Care Facility \\
\hline Education Use & Retirement Home \\
\hline Financial Institution & Student Residences \\
\hline Fire Hall & \\
\hline Library & \\
\hline Massage Therapy & \\
\hline Medical Office & \\
\hline Museum & \\
\hline Office & \\
\hline Park & \\
\hline Passenger Terminal & \\
\hline Performing Arts Studio & \\
\hline Personal Service Shop & \\
\hline Pet Services & \\
\hline Police Station & \\
\hline Post-Secondary School & \\
\hline Production Studio & \\
\hline Religious Education Use & \\
\hline Retail Store & \\
\hline Software Development and Processing & \\
\hline Veterinary Hospital & \\
\hline Wellness Centre & \\
\hline
\end{tabular}




\section{DEMOGRAPHIC ANALYSIS OF DOWNTOWN YONGE STREET}

Downtown Yonge Street is currently undergoing a dramatic transformation. The neighbourhood is experiencing a significant shift in its residential and commercial landscape. The demographics of residents of Downtown Yonge Street are changing. These demographics were analyzed using Census data from Statistics Canada for the years, 2016 and 2006. 26 Census Tracts were combined for the year, 2016 (Statistics Canada, 2017 a-z) and three Census Tracts were combined for the year, 2006 (Statistics Canada, 2007 a, b, \& c). The Census Tracts roughly coincide with the boundaries of the Study Area. Due to data limitations, the Census Tracts include the Study Area in addition to one block west of the Study Area. Therefore, the Census Tracts encompass Bloor Street to the north, College/Carlton Street to the south, Queens Park Crescent West to the west and Church Street to the east. By comparing the results over a ten-year period, a trend in the demographics of residents emerges. Population size, population density, number of immigrants, number of visible minorities, age, household type, median household income, occupation, and educational attainment are key elements that were analyzed based on findings from the literature review in Chapter 2.

\section{Population Growth and Density}

The population of the neighbourhood is increasing exponentially. There were 17,457 people living in the neighbourhood in 2006 . The population grew to 24,181 in 2016 . Over the ten-years period, 6,724 people moved into the neighbourhood representing population growth equal to $39 \%$. The density of the neighbourhood is also increasing rapidly. The number of people per square kilometre increased from approximately 17,115 in 2006 to 23,476 in 2016 . This is a $37 \%$ change in density. The neighbourhood is highly diverse with $38 \%$ of the population which identified as an immigrant and $51 \%$ of the population which identified as a visible minority in 
2016. For those who identified as a visible minority, 44\% are Chinese, 18\% are South Asian and $6 \%$ are Black.

Age

The population of the neighbourhood is young with $37 \%$ of the population between the ages of 20 and 29 in 2016 . Although 20 to 29 years is the largest age cohort, the 15 to 19 years' age cohort is expanding the most rapidly with $177 \%$ growth between 2006 and 2016 . This group is followed by the 85 years and over age cohort which experienced an $110 \%$ increase in population and the 20 to 24 years' age cohort with a growth of $100 \%$.

\section{Household Type and Median Income}

Couple households

without children, couple

households with children, and

one-person households are all

increasing in number at

relatively the same rate.

Paradoxically, the median

incomes of these household

types are changing. The median

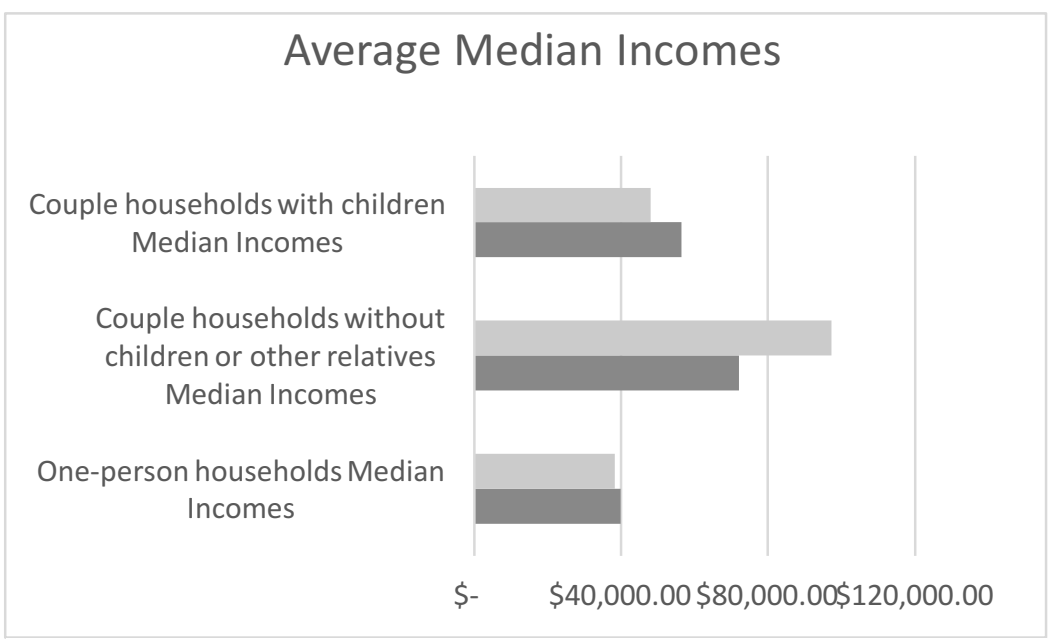

Figure 8. Average median incomes of residents in Downtown Yonge Street between 2006 and 2016. (Source: Statistics Canada, 2017a-z; Statistics Canada,2007a, $b, \& c$ )

income of couple households without children increased by $35 \%$ from $\$ 71,985.67$ in 2006 to $\$ 97,368.62$ in 2016 . The median income of couple households with children decreased by $15 \%$ from $\$ 56,358.00$ in 2006 to $\$ 48,093.54$ in 2016 . Whereas, the median income of single households decreased slightly by $4 \%$ from $\$ 39,817.00$ to $\$ 38,265.04$. If adequate Census data 
were made available, further research into income brackets would provide a more fulsome understanding of this trend.

\section{Occupation}

The top three types of occupations of residents include Business: finance and administration occupations; Occupations in education, law and social; community and government services; and Sales and service occupations in both 2006 and 2016. These occupations are generally well-paying. However, it is important to note that the data comes from a fraction of the total respondents with a $66 \%$ response rate in 2006 and a $60 \%$ response rate in 2016. There were no significant changes in the types of occupations over the 10-years period.

\section{Educational Attainment}

Residents in the neighbourhood are highly educated with $72 \%$ of the population aged 15 years or older having either college or university qualifications compared to the national statistic of $54 \%$ of Canadians

\section{Educational Attainment}

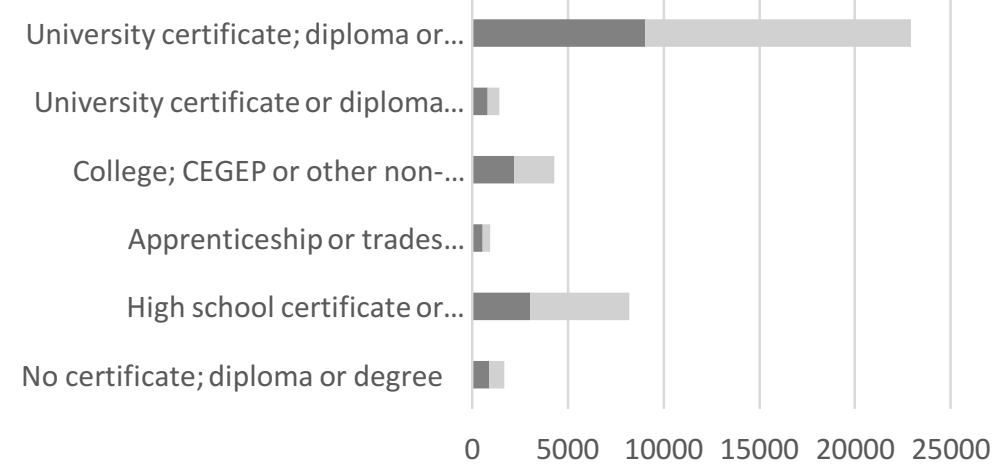

Figure 9. Levels of educational attainment of residents in Downtown Yonge Street between 2006 and 2016. (Source: Statistics Canada, 2017a-z; Statistics Canada,2007a, $b, \& c$ )

aged 25 to 64 years (Statistics Canada, 2017, November 29). This statistic would be even higher for the neighbourhood if respondents who are 25 years or older were surveyed rather than 15 years or older.

Between 2006 and 2016, the number of people who held a high school certificate or equivalent rose from $18 \%$ in 2006 to $22 \%$ in 2016 by a growth rate of $71 \%$. This could be due to 
the growth of the 15 to 19 years and 20 to 24 years' age cohorts at respective growth rates of $177 \%$ and $100 \%$. It could also be due to the number of immigrants who are moving into the neighbourhood with an increase from 6,840 immigrants in 2006 to 9,165 immigrants in 2016, representing a growth rate of $34 \%$. However, more research into these types of correlations needs to be conducted to draw conclusive results.

The number of people with apprenticeship or trades certificates, or diplomas significantly fell from $3 \%$ in 2006 to $2 \%$ in 2016 by a rate of $-28 \%$. Those with college, CEGEP or other nonuniversity certificates or diplomas fell slightly from $13 \%$ to $9 \%$ by a rate of $-2 \%$. The number of people who held a university certificate or diploma below the bachelor level fell considerably from $5 \%$ to $3 \%$ by a rate of $-25 \%$. This category is defined by Statistics Canada (2016) as “...persons who have obtained a university certificate or diploma below the bachelor level and who have not obtained any higher degrees, certificates or diplomas. University certificates or diplomas are normally connected with professional associations in fields such as accounting, banking, insurance or public administration. The certificates and diplomas referred to in this category do not require a bachelor's degree as a prerequisite." The number of people who held a university certificate, diploma or degree rose from 55\% in 2006 to $60 \%$ in 2016 by a growth rate of $54 \%$. This information would indicate that a trend is developing where residents in the neighbourhood are becoming more educated at a higher level of educational attainment. There are substantially more university graduates than college, CEGEP, apprenticeship or trades graduates. The number of people who are graduating from university is also growing more quickly than other educational institutions. 


\section{DEVELOPMENT APPLICATIONS FOR DOWNTOWN YONGE STREET}

There are 66 development applications for Yonge Street registered with the City of Toronto and nine in the Study Area. Most of these propose high-rise condominium towers atop existing heritage buildings with large-scale retail at grade (City of Toronto, 1998-2018a). If the nine development applications are approved and built, as proposed, they will add 4,799 residential units of varying sizes to help house the incoming residents who will inhabit Downtown Yonge Street (City of Toronto, 1998-2018a). As a result, there has been significant loss of local iconic businesses, leaving large expanses of vacant storefronts and chains (Mitchell, 2017). This has opened the door to development that is out of character for the historic landscape.

Three development projects will be examined in detail. Two development projects at 501 Yonge Street and 480 Yonge Street are both at the Notice of Approval Conditions (NOAC) stage of the site plan approval process with the City of Toronto. NOAC is the first of two stages for the site plan approval process. It sets out the pre- and post-approval conditions to be satisfied following a satisfactory application, and the supporting studies and reports required. These conditions must be met before the final site plan approval, the second stage of the site plan approval process (City of Toronto, 1998-2018b). 501 Yonge Street offers an example of a property without any heritage buildings or attributes. 480 Yonge Street provides an example of a property that is more characteristic of the built form in the Study Area with several designated and listed heritage buildings. The third development project at 606 Yonge Street was recently built in 2016. It was chosen to provide further context to assess development trends in the Study Area and how they are changing the types of commercial tenants who are attracted to the Study Area. The commercial tenants, which previously existed or currently exist at the sites of the three 
development applications, were categorized according to one of three groupings: local, new entrepreneurial, or corporate or chain (Zukin, 2009). 


\section{Yonge Street}

The development application for 501 to 521 Yonge Street; 6 to 8 Alexander Street and 23 Maitland Street (“501 Yonge Street”) encompasses the following 19 municipal addresses: 501 Yonge Street; 503 Yonge Street; 505 Yonge Street; 505A Yonge Street; 507 Yonge Street; 509 Yonge Street; 511 Yonge Street; 511A Yonge Street; 513 Yonge Street; 513A Yonge Street; 513B Yonge Street; 515 Yonge Street; 517 Yonge Street; 519 Yonge Street; 521 Yonge Street; and 523 Yonge Street; 6 Alexander Street; 8 Alexander Street; and 23 Maitland Street (Canada Post, n.d.). The property is located on a $3,492 \mathrm{~m}^{2}$ lot fronting onto Yonge Street between Maitland Street to the north and Alexander Street to the south (City of Toronto, 2013, September 23).

\begin{tabular}{|l|l|}
\hline & 501 Yonge Street \\
\hline Lot Size & $3,492 \mathrm{~m}^{2}$ \\
\hline Heritage Designations & 0 \\
\hline
\end{tabular}

Table 2. Lot Size and Heritage at 501 Yonge Street. (Source: City of Toronto, 2013, September 23).

Two applications were submitted for 501 Yonge Street, one is a Rezoning Application that was submitted on May 5, 2011 and is now closed; and the other is a Site Plan Approval Application which was submitted on April 30, 2015 with an NOAC issued on July 5, 2017 (City of Toronto, 1998-2018a).

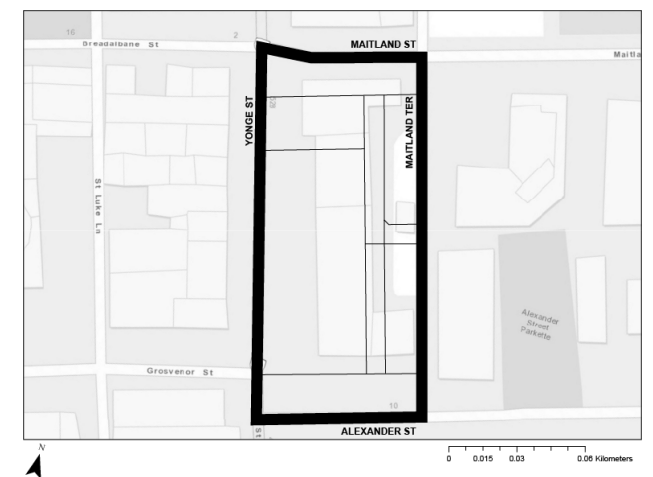

Figure 10. Location of 501 Yonge Street (Source: Anna Flood).

A two-storey building previously existed on the site. It was demolished in 2015. This building was constructed in the 1970s and, therefore, it differed from the other buildings in the Study Area (Skira, 2011, April 6). The building was not a designated or listed heritage building with the City of Toronto Heritage Register (City of Toronto, 1998-2018c). Although the property falls within the boundaries of the Historic Yonge Street Heritage Conservation District, it is 
considered a non-contributing property meaning “... the property was developed outside of the period of significance, or has lost the integrity of building features and architectural style" (City of Toronto, 2016a, p. 15). Photographs from the City of Toronto Archives show that the original building fit the built form typology of the Study Area (see figure 10). It was demolished to make way for the construction of the Yonge Subway Line in the 1950s (see figure 11) (City of Toronto Archives, n.d.).

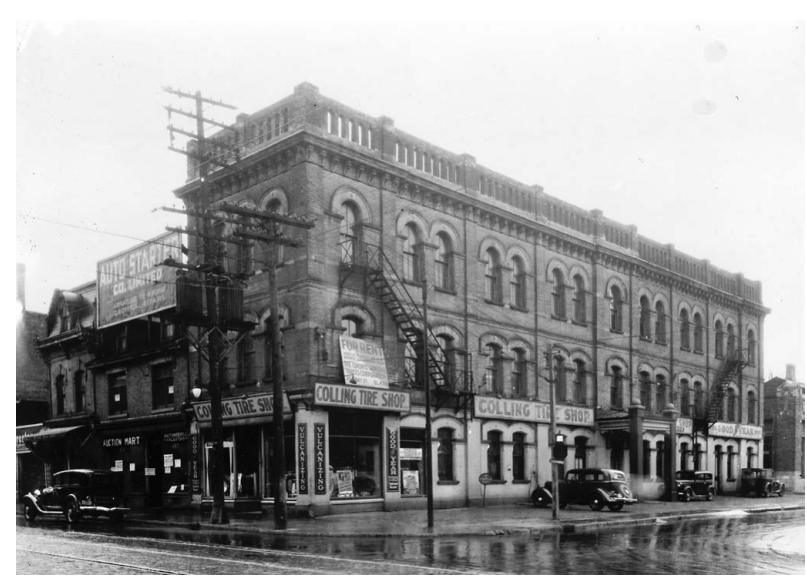

Figure 11. Collings Tire Shop at 501 Yonge Street in 1929.

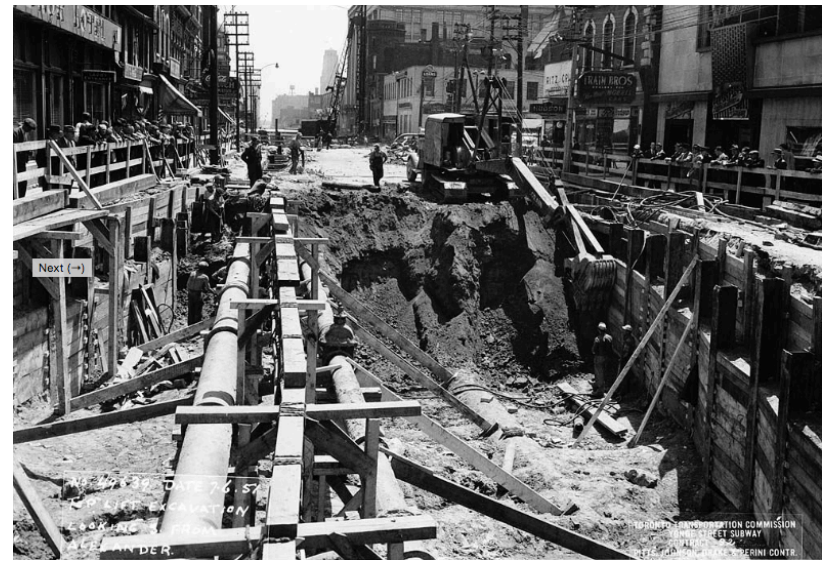

Figure 12. Subway Construction Looking south from Alexander Street at 501 Yonge Street in 1951. (Source: City of Toronto Archives, n.d.)

The property was zoned as Commercial-Residential under the Zoning By-law 438-86, meaning it can support a mix of commercial and residential uses. The building, that was demolished in 2015, included a mix of uses: restaurants and small retail vendors on the ground level, and office and retail on the second floor. The eastern portion of the site was used as surface parking and car share spaces (City of Toronto, 2013, September 23). In May 2015, a total of 19 businesses were present prior to the demolition of the building (Google Maps Street View, 2015, May). Of these 19 businesses, 17 businesses (84\%) fit within the "local" category and two businesses fit within the "corporate" category (11\%) (see Table 3). 


\begin{tabular}{|c|c|c|c|c|c|}
\hline & Name of Business & Local & $\begin{array}{c}\text { New } \\
\text { Entrepreneurial }\end{array}$ & Corporate & Address of Business \\
\hline 1 & Braz.1.L Esfiha House & $\mathrm{X}$ & & & 11 Maitland Street \\
\hline 2 & Cocina Lucero & $\mathrm{X}$ & & & $\begin{array}{l}523 \text { Yonge Street and } 7 \\
\text { Maitland Street }\end{array}$ \\
\hline 3 & $\begin{array}{l}\text { Ali Baba's, Middle } \\
\text { Eastern Cuisine }\end{array}$ & & & $\mathrm{X}$ & 501 Yonge Street \\
\hline 4 & New NYC Collection & $\mathrm{X}$ & & & 505 Yonge Street \\
\hline 5 & $\begin{array}{l}\text { Millenium } \\
\text { Accessories \& Body } \\
\text { Piercings } \\
\end{array}$ & $\mathrm{X}$ & & & 505 Yonge Street \\
\hline 6 & Fickle & $\mathrm{X}$ & & & 507 Yonge Street \\
\hline 7 & Wind Mobile & & & $\mathrm{X}$ & 509 Yonge Street \\
\hline 8 & \begin{tabular}{|l} 
(Vacant) \\
\end{tabular} & & & & \\
\hline 9 & $\begin{array}{l}\text { Jong Park Tae Kwon- } \\
\text { DO }\end{array}$ & $\mathrm{X}$ & & & 511 Yonge Street \\
\hline 10 & $\begin{array}{l}\text { CKT Sports Martial } \\
\text { Arts Supplies }\end{array}$ & $\mathrm{X}$ & & & 511 Yonge Street \\
\hline 11 & WirelessWarehouse.ca & $\mathrm{X}$ & & & 513 Yonge Street \\
\hline 12 & Papaya Hut & $\mathrm{X}$ & & & 513 Yonge Street \\
\hline 13 & $\begin{array}{l}\text { Kleen Air Dancing } \\
\text { Shoes }\end{array}$ & $\mathrm{X}$ & & & 513 Yonge Street \\
\hline 14 & The NYC Collection & $\mathrm{X}$ & & & 515 Yonge Street \\
\hline 15 & $\begin{array}{l}\text { Kathmandu } \\
\text { Restaurant }\end{array}$ & $\mathrm{X}$ & & & 517 Yonge Street \\
\hline 16 & Wrap \& Roll & $\mathrm{X}$ & & & 519 Yonge Street \\
\hline 17 & VAPE Toronto & $\mathrm{X}$ & & & 521 Yonge Street \\
\hline 18 & Kokyo Sushi & $\mathrm{X}$ & & & 6 Alexander Street \\
\hline 19 & $\begin{array}{l}\begin{array}{l}\text { Pi-Tom's Thai } \\
\text { Cuisine }\end{array} \\
\end{array}$ & $\mathrm{X}$ & & & 8 Alexander Street \\
\hline
\end{tabular}

Table 3. Former Businesses at 501 Yonge Street. (Source: Google Maps, 2015, May). 


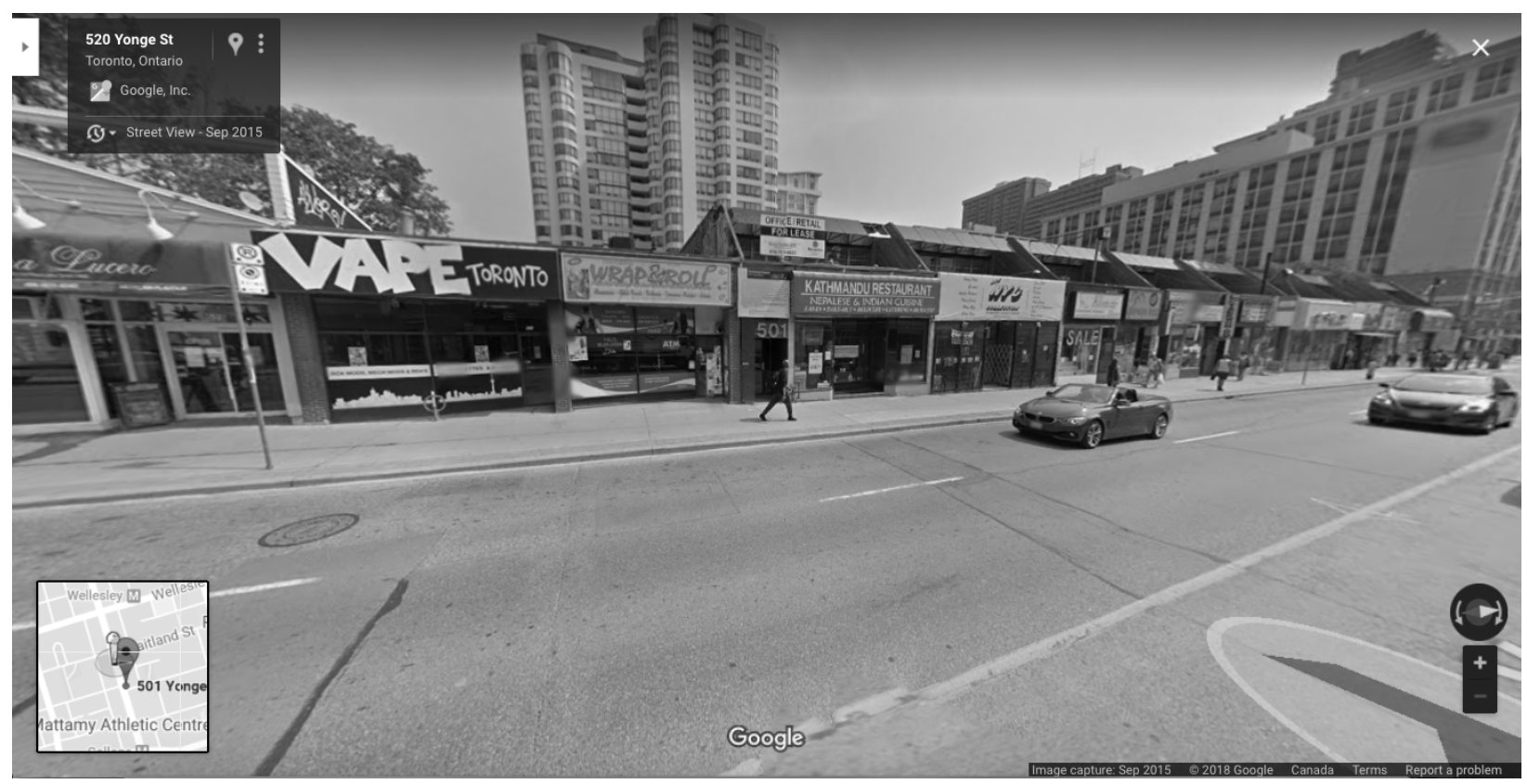

Figure 13. 501 Yonge Street prior to redevelopment in September 2015 (Source: Google Maps Street View, 2015, September).

The Rezoning Application mainly increased the height and density of the property through Zoning By-law Amendment (ZBA), By-law No. 139-2014, which was passed on February 20, 2014 (City of Toronto, 2014, February 20). The site was zoned CommercialResidential (CR3.0 C2.0 R3.0) under Zoning By-law 438-86. The maximum density permitted was 3.0 times the lot area: 2.0 times the lot area for commercial uses and 3.0 times the lot area for residential uses. The maximum height permitted was 18 metres. The total number of parking spaces required was 534 spaces. The ZBA allowed for a maximum density of 15.2 times the lot area, a maximum height of 174 metres and a minimum of 235 parking spaces (City of Toronto, 2013, September 23).

The Site Plan Approval Application proposes two mixed-use buildings. One tower will be 23 storeys or 80 metres and the other tower will be 52 storeys or 174 metres. The Application proposes a maximum total GFA of $53,183 \mathrm{~m}^{2}$ : a residential GFA of 51,916 $\mathrm{m}^{2}$ and a nonresidential GFA of 1,266 $\mathrm{m}^{2}$ (City of Toronto, 2013, September 23). The ZBA allows for a maximum total GFA of 53,190 $\mathrm{m}^{2}$ : a residential GFA of $51,920 \mathrm{~m}^{2}$ and a non-residential GFA of 
$1,270 \mathrm{~m}^{2}$. There will be 776 residential units and an undefined number of retail unit(s). The

Application also proposes 235 parking spaces: 185 parking spaces for residents, 47 parking spaces for residential visitor and 3 car-share parking spaces (City of Toronto, 2014, February

20).

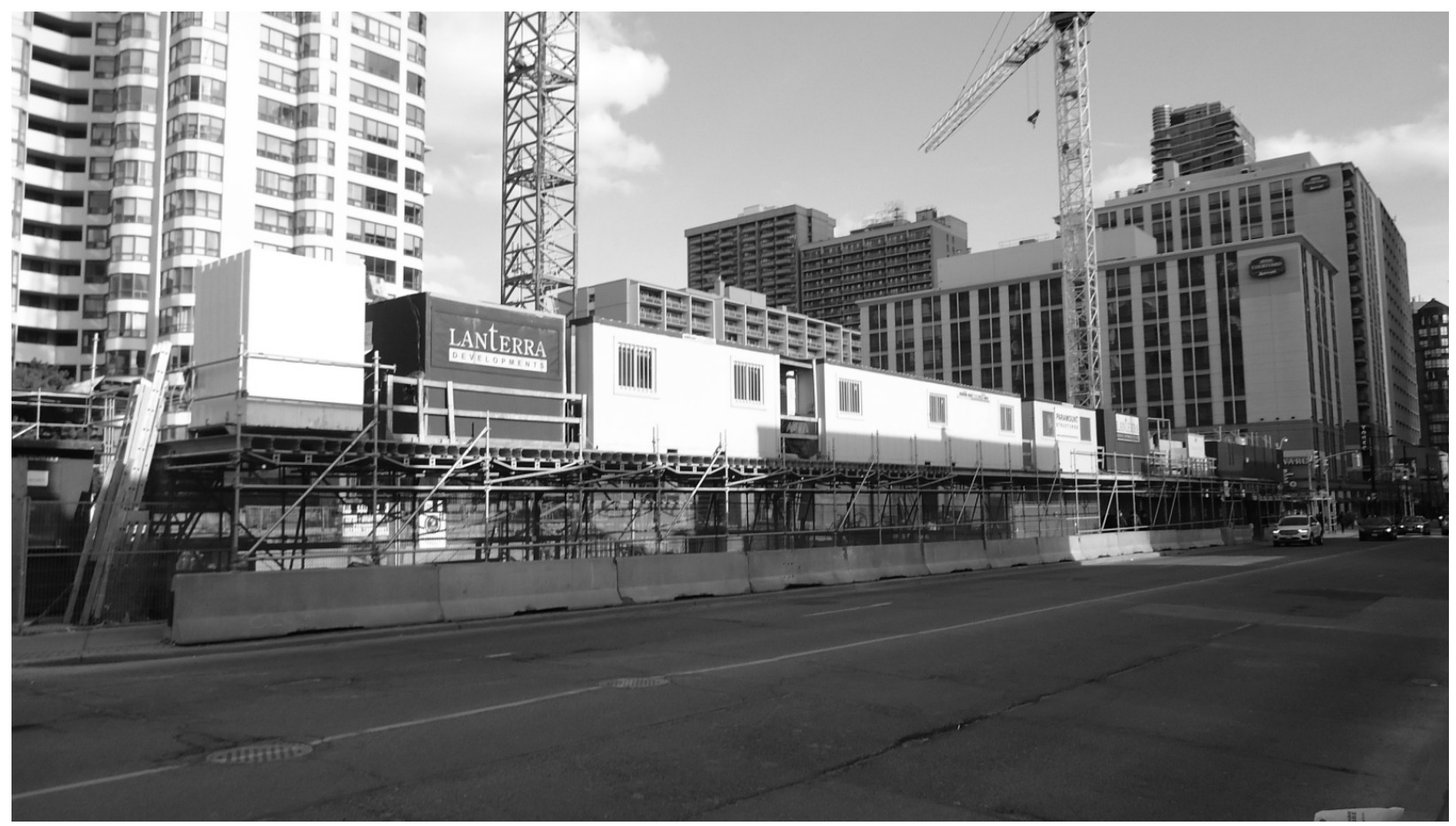

Figure 14. 501 Yonge Street during redevelopment in April 2018. (Source: Anna Flood).

\begin{tabular}{|l|l|}
\hline \multicolumn{2}{|c|}{ The Development Application } \\
\hline Project number & 15149779 STW 27 SA \\
\hline Status & NOAC Approved \\
\hline Storeys & 23 (North Tower) and 52 (South Tower) \\
\hline Total Gross Floor Area (GFA) & $53,183 \mathrm{~m}^{2}$ \\
\hline Number of Residential Units & 776 \\
\hline Residential GFA & $51,916 \mathrm{~m}^{2}(98 \%)$ \\
\hline Number of Retail Units & Undefined \\
\hline Retail GFA & $1,266 \mathrm{~m}^{2}(2 \%)$ \\
\hline Density & 15.2 \\
\hline Number of Parking Spots & 235 \\
\hline
\end{tabular}

Table 4. The Development Application at 501 Yonge Street. (Source: City of Toronto, 2013, September 23).

As approved in the ZBA, the proposed retail GFA is $1,256 \mathrm{~m}^{2}$ (City of Toronto, 2014, February 20). At this stage in the Site Plan Approval Application process, the ground floor architectural plans do not define the number nor the size of the individual retail units. Instead, the 
retail space reads as one open space. This is typical of the development process. Developers tend to wait until they have secured commercial tenant(s) to define retail units because the size of the retail units will depend on the space needs of the commercial tenant. The ground floor architectural plans show that there will be five retail entrances on Yonge Street, one retail entrance on Maitland Street to the north and four retail entrances on Alexander Street to the south. As prescribed by the North Downtown Yonge Urban Design Guidelines (City of Toronto, 2013a) and secured by the ZBA (City of Toronto, 2014, February 20), there will also be “A maximum retail design expression for ground floor retail unit facades along the Yonge Street frontage of 5.0 metres (+/-0.25 metres) intervals" (p.12). The Application adheres to the intent of the Historic Yonge Street HCD (City of Toronto, 2016a) and the North Downtown Yonge Urban Design Guidelines (City of Toronto, 2013a) as far as ensuring more retail entrances and narrower retail frontages with street level access on Yonge Street. More retail entrances and narrower retail frontages will help to maintain the appearance of traditional built form. Nonetheless, streetscape animation will still be undermined if there are fewer retail units occupied by fewer than the original 19 small businesses on this block of Yonge Street. Meanwhile, the residential GFA has increased $51,916 \mathrm{~m}^{2}$, representing $98 \%$ of the property use where the non-residential GFA is $2 \%$ of the property use. 


\section{Yonge Street}

The development application at 480-494 Yonge Street and 3 Grosvenor Street (“480

Yonge Street”) encompasses the following eleven municipal addresses: 480 Yonge Street; 482

Yonge Street; 484 Yonge Street; 486 Yonge Street; 488 Yonge Street; 488A Yonge Street 490

Yonge Street; 490A Yonge Street; 492 Yonge Street; 494 Yonge Street; and 3 Grosvenor Street

(Canada Post, n.d.). The property is located on an $1,829.50 \mathrm{~m}^{2}$ lot front onto Yonge Street at the corner of Yonge Street and Grosvenor Street to the north (City of Toronto, 2017, April 3).

\begin{tabular}{|c|c|}
\hline \multicolumn{2}{|c|}{480 Yonge Street } \\
\hline Lot Size & $1,829.50 \mathrm{~m}^{2}$ \\
\hline \multicolumn{2}{|c|}{ Heritage Designations } \\
\hline \multicolumn{2}{|c|}{ The building at $480-482$ Yonge Street } \\
\hline 480 Yonge Street & $\begin{array}{l}\text { Designated Part IV on July 7, } 2017 \text { by By-law } \\
\text { no. } 770-2017\end{array}$ \\
\hline 482 Yonge Street & $\begin{array}{l}\text { Designated Part IV on July 7, } 2017 \text { by By-law } \\
\text { no. } 770-2017\end{array}$ \\
\hline \multicolumn{2}{|c|}{ The building at 484-488 Yonge Street } \\
\hline $484-488$ Yonge Street & $\begin{array}{l}\text { Designated Part IV on July 7, } 2017 \text { by By-law } \\
\text { no. } 770-2017\end{array}$ \\
\hline 484 Yonge Street & $\begin{array}{l}\text { Designated Part IV on March 10, } 2016 \text { by By- } \\
\text { law no. 235-2016. Contributing property in } \\
\text { the Historic Yonge Street HCD. }\end{array}$ \\
\hline 486 Yonge Street & $\begin{array}{l}\text { Designated Part IV on March 10, } 2016 \text { by By- } \\
\text { law no. 235-2016. Contributing property in } \\
\text { the Historic Yonge Street HCD. }\end{array}$ \\
\hline 488 Yonge Street & $\begin{array}{l}\text { Designated Part IV on March 10, } 2016 \text { by By- } \\
\text { law no. 235-2016. Contributing property in } \\
\text { the Historic Yonge Street HCD. }\end{array}$ \\
\hline 488A Yonge Street & $\begin{array}{l}\text { Designated Part IV on March 10, } 2016 \text { by By- } \\
\text { law no. 235-2016. Contributing property in } \\
\text { the Historic Yonge Street HCD. }\end{array}$ \\
\hline \multicolumn{2}{|c|}{ The building at 490 Yonge Street $-490 \mathrm{~A}$ Yonge Street } \\
\hline 490 Yonge Street & $\begin{array}{l}\text { Designated Part IV by By-law 770-2017 on } \\
\text { July } 7,2017\end{array}$ \\
\hline \multicolumn{2}{|c|}{ The building at $492-494$ Yonge Street and 3 Grosvenor Street } \\
\hline 492 Yonge Street & $\begin{array}{l}\text { Designated Part IV by By-law 770-2017 on } \\
\text { July } 7,2017\end{array}$ \\
\hline \multicolumn{2}{|c|}{ Heritage Listings } \\
\hline \multicolumn{2}{|c|}{ The building at 490 Yonge Street $-490 \mathrm{~A}$ Yonge Street } \\
\hline 490 Yonge Street & Listed on March 10, 2016 \\
\hline
\end{tabular}


490A Yonge Street

Listed on March 10, 2016

Table 5. Lot Size and Heritage at 480 Yonge Street. (Source: City of Toronto, 1998-2018c).

Two applications were submitted for 480 Yonge

Street, one is a Rezoning Application which was

submitted on December 23, 2014 and approved by

Toronto City Council on May 24, 2017 and the other is a

Site Plan Approval Application which was submitted on

November 29, 2016 with an NOAC issued on January 7,

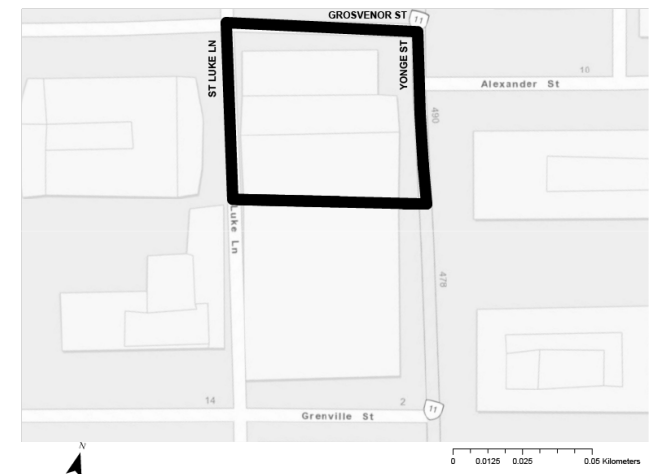

Figure 15. Location of 480 Yonge Street (Source: Anna Flood).

2017 (City of Toronto, 1998-2018c).

Four buildings, ranging from two to three storeys, previously existed on the site as well as a substantially taller clock tower that was part of Old Fire Hall No. 3. At 480-482 Yonge Street, there is a three-storey mixed-use building with two rental dwelling units. At 484-488 Yonge Street, there is a two-storey mixed-use building with eight dwelling units. At 490 Yonge Street, there is a two-storey commercial building. At 492-494 Yonge Street and 3 Grosvenor Street, there is a three-storey mixed-use building with commercial uses on the ground floor and 16 rental dwelling units on the upper floor (City of Toronto, 2017, April 3).

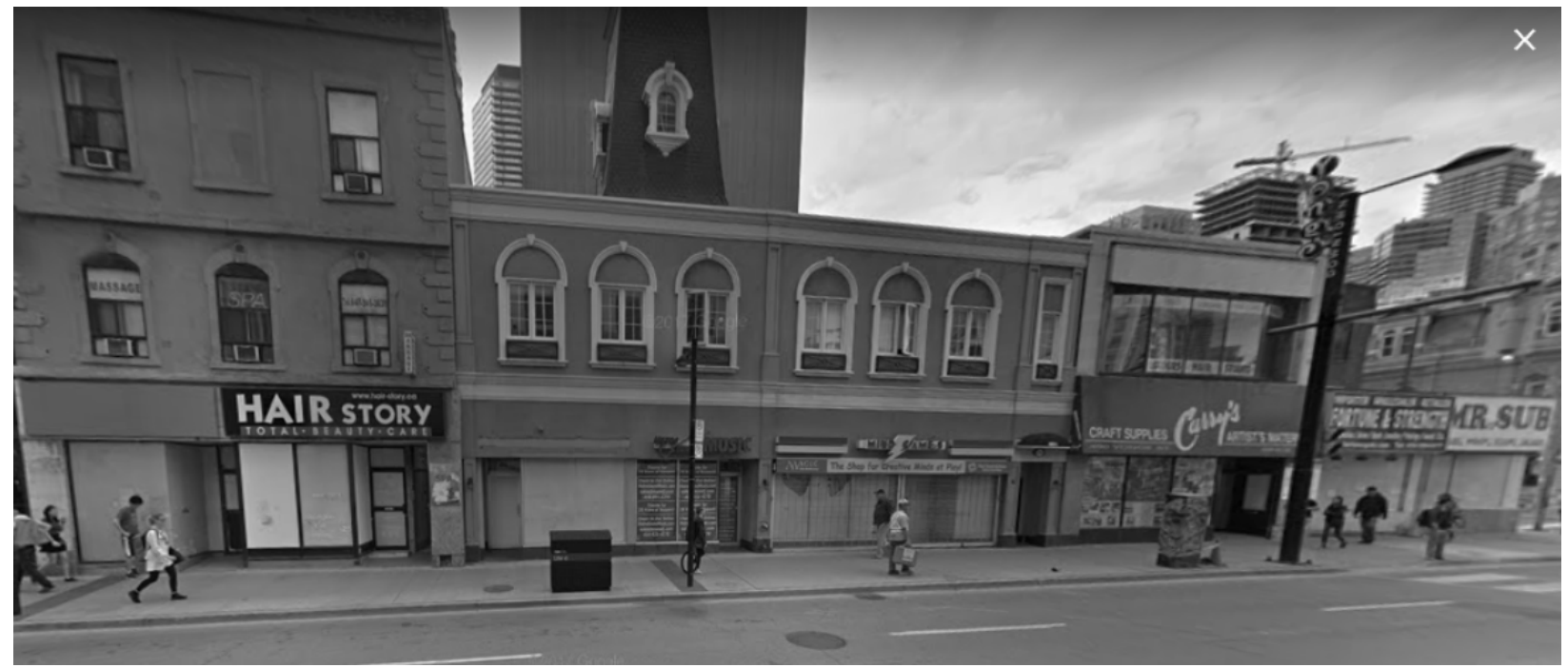

Figure 16. 480 Yonge Street prior to redevelopment in August 2017. (Source: Google Maps Street View, 2017, August). 
The properties at 480-482, 484-488 and 490 Yonge Street are all designated under Part V of the Ontario Heritage Act (1990) by By-law No. 235-2016. The intent of this By-law is "To designate the Historic Yonge Street Conservation District and adopt the Historic Yonge Street Heritage Conservation District Plan” (City of Toronto, 2016, March 10, p. 1). The properties are considered contributing properties within this framework, meaning the properties are either 1) “ ...listed on the City's Heritage Register”; 2) “... primarily developed within the period of significance (1860-1954), or built shortly after the period of significance and with a building height that is taller than other contributing properties, but that exhibits a mid-century modern architectural style"; or 3) “... demonstrate integrity of building features that are consistent with their date and style of construction, exhibit the heritage attributes of HYHCD and are consistent

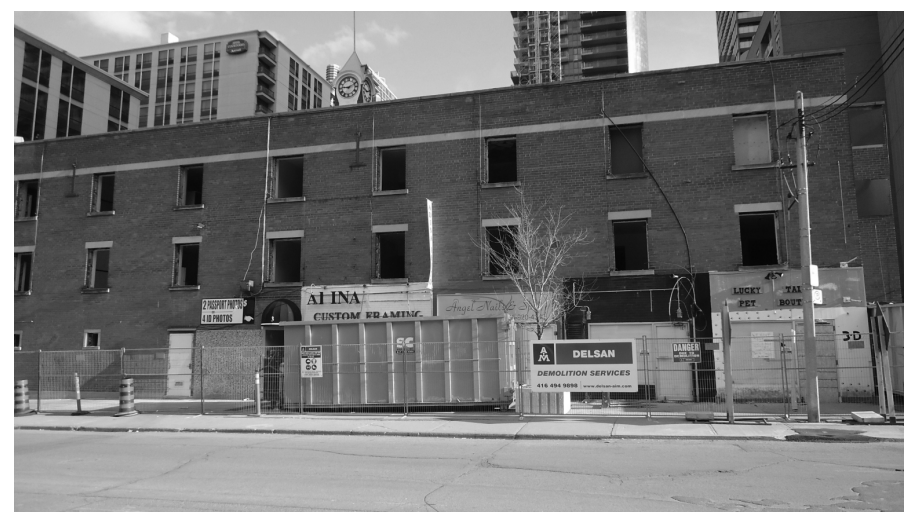
Figure 17. 492-494 Yonge Street and 3 Grosvenor Street looking south on Grosvenor Street prior to demolition in April 2018. (Source: Anna Flood). with its cultural heritage value" (City of Toronto, 2016a, p. 15). Like the property at 501 Yonge Street, the property at 492-494 Yonge Street and 3 Grosvenor Street is considered a noncontributing property (City of Toronto, 2016a). It will be demolished in 2018 .

The properties at 480-482, 484-488, 490 and 492 Yonge Street were all designated under Part IV of the Ontario Heritage Act (1990) by By-law No. 770-2017 (City of Toronto, 2017, July 7a). The intent of this By-law is "To designate the property at 480 Yonge Street as being of cultural heritage value or interest" (City of Toronto, 2017, July 7, p. 1) by meeting the criteria for municipal designation under all three categories of design, associative and contextual value. The property at 480 Yonge Street was built in 1864 for the business and residence of a grain and feed 
merchant. The Blue Posts Hotel operated on-site in the late $19^{\text {th }}$ century followed by the book store and art gallery of John Britnell in the early 1900s. In 1912, the Bank of Montreal leased the property and added the third storey and classical detailing as designed by architects, Darling and Pearson. Motor cycle dealer, Ross Cycles, was among one of the retailers during the $20^{\text {th }}$ century (City of Toronto, 2017, July 7a). As mentioned in Chapter 1, this was also the site of St. Charles Tavern (see Figure 15) (City of Toronto, 2016a).

Like the building at 480 Yonge Street, the building at 484 Yonge Street has an important history. It is the site of a late $19^{\text {th }}$ century clock tower associated with a fire hall (since demolished in 1950). This clock tower is a local landmark on Yonge Street. Both properties are connected to the

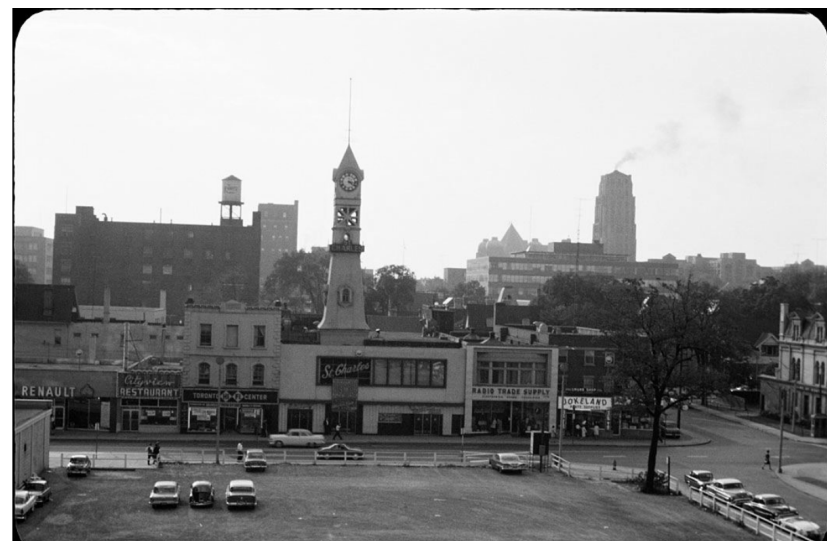
Figure 18. St. Charles Tavern at 480 Yonge Street in October 1961. (Source: City of Toronto Archives, n.d.) development of Yonge Street as Toronto's "Main Street" and associated with prominent Toronto architects (City of Toronto, 2017, March 27).

The redevelopment of the site will include the conservation of both designated properties at 480 and 484 Yonge Street. The existing Clock Tower at 484 Yonge Street and the façade of the heritage building at 480 Yonge Street will be conserved and incorporated into the redevelopment (City of Toronto, 2017, April 3).

In addition to designation under part IV of the Ontario Heritage Act (1990), the building at 490 Yonge Street was individually listed on the City of Toronto Heritage Register on March 10, 2016 (City of Toronto, 1998-2018c). However, City staff agreed with the findings of the Heritage Impact Assessment that “... the property had diminished heritage value due to 
numerous alterations that have significantly altered its early $20^{\text {th }}$ century design. The property does not effectively communicate its heritage value at street frontage and therefore does not need to be retained" (City of Toronto, 2017, April 3, p. 23). Therefore, the property at 490 Yonge Street was demolished in 2018.

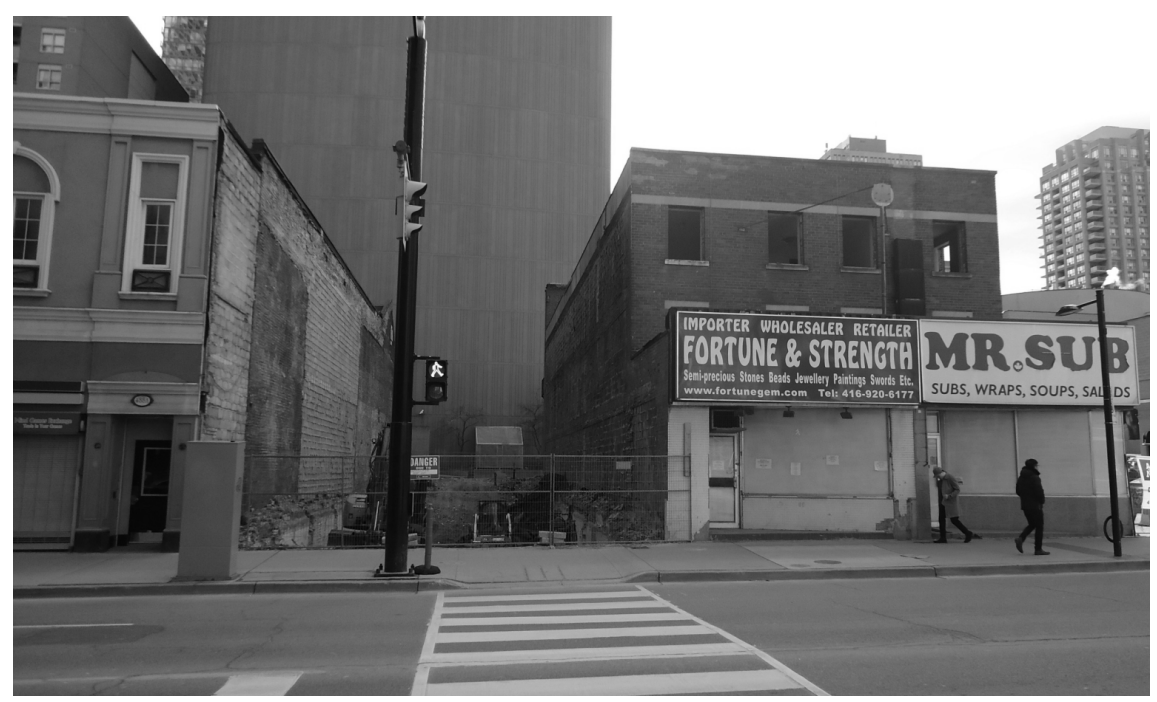

Figure 19. 490 Yonge Street following demolition in Apri1 2018. (Source: Anna Flood).

The property was zoned as Commercial-Residential under Zoning-by law 438-86 and Zoning by-law 569-13, meaning it can support a mix of commercial and residential uses. All buildings except for the building at 492-494 Yonge Street were occupied by commercial uses at grade and residential above. In total, the property has 26 rental units on the site which will be demolished and replaced in the proposed property in accordance with Chapter 667: Residential and Rental Property Demolition and Conversion Control of the City of Toronto Municipal Code. 21 of these existing units have affordable or mid-range rents. Most of the commercial units on the site are now vacant (City of Toronto, 2017, April 3). As of August 2017, a total of 12 businesses were present on the site (Google Maps Street View, 2017, August). Of these 12 businesses, 10 businesses ( $83 \%$ ) fit within the "local" category and two businesses fit within the "corporate" category (17\%) (see table 6). 


\begin{tabular}{|c|c|c|c|c|c|}
\hline & $\begin{array}{l}\text { Name of } \\
\text { Business }\end{array}$ & Local & $\begin{array}{c}\text { New } \\
\text { Entrepreneurial }\end{array}$ & Corporate & Address of Business \\
\hline 1 & $\begin{array}{l}\text { (Vacant } \\
\text { storefront) - } \\
\text { (Sevan Art } \\
\text { Gallery in May } \\
\text { 2015) }\end{array}$ & $\mathrm{X}$ & & & 480 Yonge Street \\
\hline 2 & Hair Story & $\mathrm{X}$ & & & 482 Yonge Street \\
\hline 3 & $\begin{array}{l}\text { (Vacant } \\
\text { storefront)- } \\
\text { (Sushi House } \\
\text { in May 2015) }\end{array}$ & $\mathrm{X}$ & & & 484 Yonge Street \\
\hline 4 & $\begin{array}{l}\text { Metro Sound \& } \\
\text { Music }\end{array}$ & $\mathrm{X}$ & & & 486 Yonge Street \\
\hline 5 & Mind Games & & & $\mathrm{X}$ & 488 Yonge Street \\
\hline 6 & Curry's Crafts & $\mathrm{X}$ & & & 490 Yonge Street \\
\hline 7 & $\begin{array}{l}\text { Fortune \& } \\
\text { Strength }\end{array}$ & $\mathrm{X}$ & & & 492 Yonge Street \\
\hline 8 & Mr. Sub & & & $\mathrm{X}$ & 494 Yonge Street \\
\hline 9 & $\begin{array}{l}\text { Adina Photo } \\
\text { Custom } \\
\text { Framing }\end{array}$ & $\mathrm{X}$ & & & 3A Grosvenor Street \\
\hline 10 & $\begin{array}{l}\text { Angel Nails } \\
\text { and Spa }\end{array}$ & $\mathrm{X}$ & & & 3B Grosvenor Street \\
\hline 11 & $\begin{array}{l}\text { Solo Sushi } \\
\text { Bekkan }\end{array}$ & $\mathrm{X}$ & & & 3C Grosvenor Street \\
\hline 12 & $\begin{array}{l}\text { Lucky Tails } \\
\text { Pet Boutique }\end{array}$ & $\mathrm{X}$ & & & 3D Grosvenor Street \\
\hline
\end{tabular}

Table 6. Former Businesses at 480 Yonge Street. (Source: Google Maps Street View, 2017, August).

The Rezoning Application mainly increased the height and density of the property through Zoning By-law Amendments (ZBAs), By-law No. 1263-2017 and 1264-2017, which were enacted and passed on November 9, 2017 (City of Toronto, 2017, November 9a; City of Toronto, 2017, November 9b). The site was zoned Commercial-Residential (CR T3.0 C2.0 R3.0) under Zoning By-Law 438-86. The maximum density permitted was 3.0 times the lot area: 2.0 times the lot area for commercial uses and 3.0 times the lot area for residential uses. The maximum height permitted was 18 metres (City of Toronto, April 3). The ZBA allowed for a maximum density of 17.76 times the lot area and a maximum height of 131 metres. The ZBA 
reduced the minimum parking requirements to 117 parking spaces (City of Toronto, 2017, November 9a; City of Toronto, 2017, November 9b).

The Site Plan Approval Application proposes one mixed-use building. One tower will be 38 storeys or 131 metres. The Application proposes a maximum total GFA of $32,495 \mathrm{~m}^{2}$ : a residential GFA of $30,362 \mathrm{~m}^{2}$ and a non-residential GFA of $2,133 \mathrm{~m}^{2}$ with $718 \mathrm{~m}^{2}$ on the ground floor, $196 \mathrm{~m}^{2}$ on a mezzanine level and $1,219 \mathrm{~m}^{2}$ on the second floor (City of Toronto, 2017, April 3). The ZBA allows for a maximum total GFA of $34,300 \mathrm{~m}^{2}$ : a residential GFA of 31,700 $\mathrm{m}^{2}$ and a non-residential GFA of $4,300 \mathrm{~m}^{2}$ of which the non-residential gross floor area located at or above grade shall not exceed $2,600 \mathrm{~m}^{2}$. There will be 451 residential units, 425 of which will be condominium units and 26 will be rental units. There will be an undefined number of retail units (City of Toronto, 2017, November 9a; City of Toronto, 2017, November 9b). Interestingly, provisions were made in the ZBAs where "the non-residential gross floor area on the ground level must be divided into a minimum of 3 non-residential units, one of which must provide direct access to the non-residential space located on the second storey; and the maximum area of one non-residential unit located on the ground level is 450 square metres." (City of Toronto, 2017, November 9a; City of Toronto, 2017, November 9b p. 2). "Despite Regulation 150.100.30(2), an eating establishment with an interior floor area greater than 1,000 square metres is permitted on the lot" (City of Toronto, 2017, November 9a, p. 3). The Application proposes 117 parking spaces: 80 parking spaces will be for residential use of which a maximum of two will be car-share parking spaces; and 35 parking spaces will be for the shared use of residents of the rental replacement dwelling units, visitors to all dwelling units, and occupants and visitors to non-residential uses (City of Toronto, 2017, April 3). 


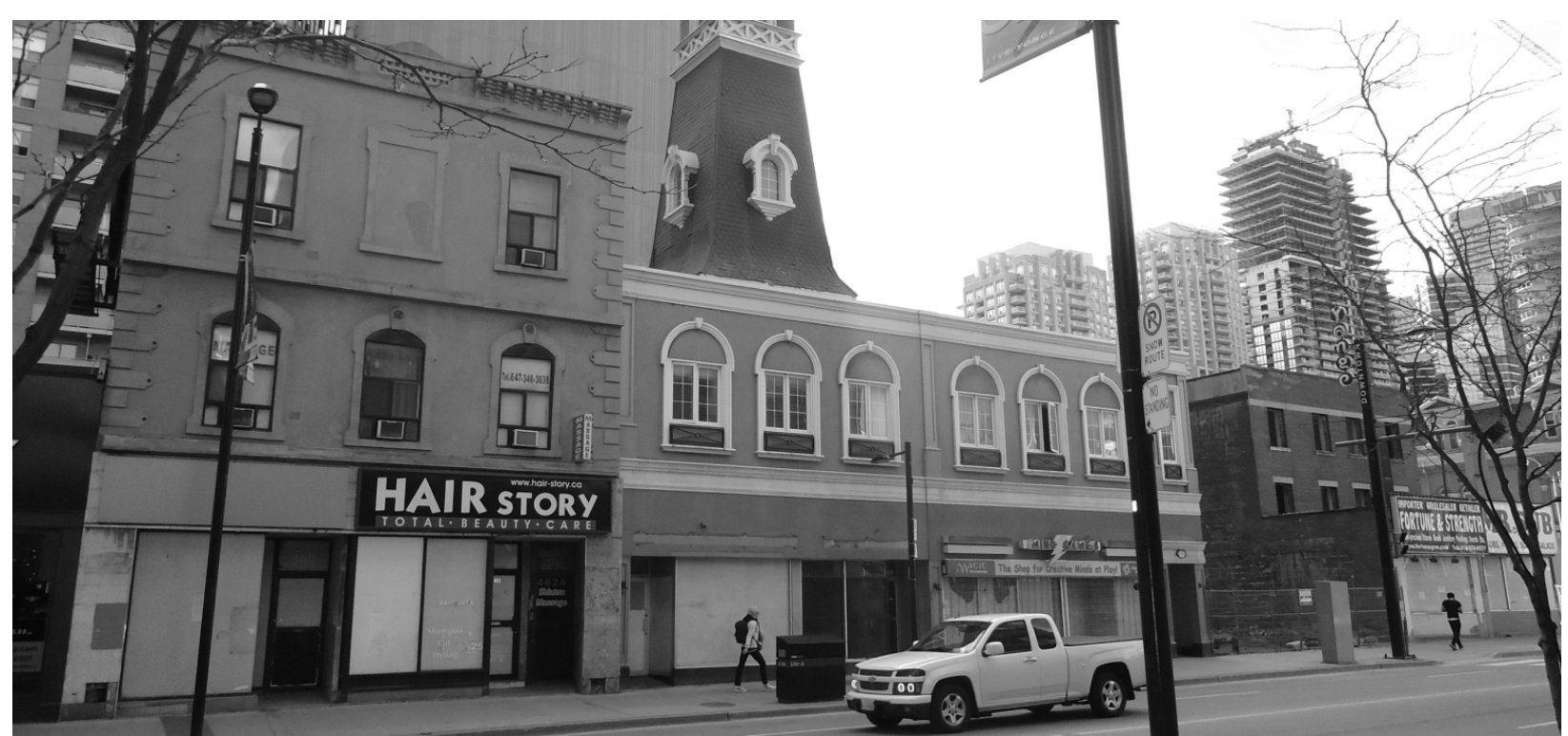

Figure 20. 480 Yonge Street during redevelopment in April 2018. (Source: Anna Flood).

\begin{tabular}{|l|l|}
\hline \multicolumn{2}{|c|}{ The Development Application } \\
\hline Project number & 16257497 STE 27 SA \\
\hline Status & NOAC Issued on January 7, 2017 \\
\hline Storeys & 38 or 131.0 metres \\
\hline Total Gross Floor Area (GFA) & $32,504.8 \mathrm{~m}^{2}$ \\
\hline Number of Residential Units & $\begin{array}{l}451(425 \text { condominium units and 26 rental } \\
\text { units })\end{array}$ \\
\hline Residential GFA & $30,254.8 \mathrm{~m}^{2}(93 \%)$ \\
\hline Number of Retail Units & Minimum 3 units \\
\hline Retail GFA & $\begin{array}{l}2,133 \mathrm{~m}^{2}, \text { maximum } 450 \mathrm{~m}^{2} \text { of a non- } \\
\text { residential unit located on the ground floor } \\
(7 \%)\end{array}$ \\
\hline Density & 17.76 \\
\hline Number of Parking Spots & $\begin{array}{l}117(80 \text { for residential visitors, 35 } \\
\text { commercial, and 2 auto share spaces })\end{array}$ \\
\hline
\end{tabular}

Table 7. The Development Application at 480 Yonge Street. (Source: City of Toronto, 2017, April 3).

As approved in the ZBA, the proposed retail GFA is $2,133 \mathrm{~m}^{2}$ from the existing retail GFA of $1,950 \mathrm{~m}^{2}$, representing a slight increase in the space that is available for potential commercial tenants. The retail space will be situated on the ground floor, the mezzanine level and second floor of the two-storey podium of the tower (City of Toronto, 2017, April 3). At this stage in the Site Plan Approval process, the ground floor architectural plans can change so the number and size of the individual retail units may change. However, it appears that there are two non- 
residential units on the ground floor; one measuring $320.84 \mathrm{~m}^{2}$ and another measuring $304.59 \mathrm{~m}^{2}$ for a total of $625.43 \mathrm{~m}^{2}$. The proposal lists $718 \mathrm{~m}^{2}$ as the amount of non-residential space on the ground floor. However, there is a note about future patio space on Grosvenor Street which will animate the street level. It appears there is one non-residential unit on the mezzanine level measuring $176.1 \mathrm{~m}^{2}$. The proposal lists $196 \mathrm{~m}^{2}$ as the amount of non-residential space on the mezzanine level.

The ground floor architectural plans also show that there will be five retail entrances on Yonge Street, and one retail entrance and one commercial entrance on Grosvenor Street to the north. According to the City staff report (City of Toronto, 2017, April 3), “Approximately five retail entrances will be located along the Yonge Street frontage, with spacing ranging from approximately 3 to 9 metres..." (City of Toronto, 2017, April 3, p. 22) and "the retail frontage will be divided into multiple bays with widths of approximately 9 metres to correspond with the historical storefront width of 480 Yonge Street” (City of Toronto, 2017, April 3, p. 22). It should be noted that this was not secured in the ZBA (City of Toronto, 2017, November 9a; City of Toronto, 2017, November 9b). Like the property at 501 Yonge Street, more retail entrances and narrower retail frontages will help streetscape animation efforts, but these efforts will continue to be undermined by fewer and larger retail units on the ground floor. Moving from 12 units, which were occupied by 12 businesses, to three larger units, it will be interesting to note what types of commercial tenants will replace these local businesses.

The residential gross floor area has increased from $1,520 \mathrm{~m}^{2}$ to $30,254.8 \mathrm{~m}^{2}$ and the development application sees $93 \%$ of the use as residential and $7 \%$ of the use as retail while office, industrial, and institutional/other uses do not exist. The shift in land use toward greater accommodation for residential use rather than non-residential uses is clear. (City of Toronto, 
2017, April 3). While there remain trade-offs with this development application, it represents a shift toward recognizing the importance of incorporating a greater number of appropriately-sized retail units at the street level. This was done through the zoning by-law amendment. 


\section{Yonge Street}

The property at 606-618 Yonge Street, 5-9 St. Joseph Street, 11-19 and 25 St. Nicholas

Street (“606 Yonge Street”) encompasses the following 16 municipal addresses: 606 Yonge

Street; 608 Yonge Street; 610 Yonge Street; 612 Yonge Street; 614 Yonge Street; 616 Yonge

Street; 618 Yonge Street; 5 St. Joseph Street; 7 St. Joseph Street; 9 St. Joseph Street; 11 St.

Nicholas Street; 13 St. Nicholas Street; 15 St. Nicholas Street; 17 St. Nicholas Street; 19 St.

Nicholas Street; and 25 St. Nicholas Street (Canada Post, n.d.).

\begin{tabular}{|c|c|}
\hline \multicolumn{2}{|c|}{606 Yonge Street } \\
\hline Lot Size & $2,705 \mathrm{~m}^{2}$ \\
\hline \multicolumn{2}{|c|}{ Heritage Designations } \\
\hline \multicolumn{2}{|c|}{ The building at 606 and 608 Yonge Street } \\
\hline 606 Yonge Street & $\begin{array}{l}\text { Designated Part IV on July 9, } 2010 \text { by By-law } \\
\text { no. } 277-2015\end{array}$ \\
\hline 608 Yonge Street & $\begin{array}{l}\text { Designated Part IV on July 9, } 2010 \text { by By-law } \\
\text { no. } 277-2015\end{array}$ \\
\hline \multicolumn{2}{|c|}{ The building at 610 and 612 Yonge Street } \\
\hline 610 Yonge Street & $\begin{array}{l}\text { Designated Part IV on March 15, } 1974 \text { by By- } \\
\text { law no. } 597-2010\end{array}$ \\
\hline 612 Yonge Street & $\begin{array}{l}\text { Designated Part IV on March 15, } 1974 \text { by By- } \\
\text { law no. } 597-2010\end{array}$ \\
\hline \multicolumn{2}{|c|}{ The building at 614 Yonge Street } \\
\hline 614 Yonge Street & $\begin{array}{l}\text { Designated Part IV on March 15, } 1974 \text { by By- } \\
\text { law no. 597-2010 }\end{array}$ \\
\hline \multicolumn{2}{|c|}{ The building at 616 Yonge Street } \\
\hline 616 Yonge Street & $\begin{array}{l}\text { Designated Part IV on March 15, } 1974 \text { by By- } \\
\text { law no. 595-2010 }\end{array}$ \\
\hline \multicolumn{2}{|c|}{ The building at 618 Yonge Street } \\
\hline 618 Yonge Street & $\begin{array}{l}\text { Designated Part IV on March 15, } 1974 \text { by By- } \\
\text { law no. } 598-2010 \text { and on June 9, } 2010 \text { by By- } \\
\text { law } 277-2015\end{array}$ \\
\hline \multicolumn{2}{|c|}{ The building at 5-9 St. Joseph Street } \\
\hline 5 St. Joseph Street & $\begin{array}{l}\text { Designated Part IV on April 14, } 1997 \text { by By- } \\
\text { law 235-2016 as a contributing property }\end{array}$ \\
\hline 9 St. Joseph Street & $\begin{array}{l}\text { Designated Part IV on April 14, } 1997 \text { by By- } \\
\text { law 235-2016 as a contributing property }\end{array}$ \\
\hline \multicolumn{2}{|c|}{ The building at 11-19 St. Joseph Street } \\
\hline 11 St. Joseph Street & $\begin{array}{l}\text { Designated Part IV on April 14, } 1997 \text { by By- } \\
\text { law 235-2016 }\end{array}$ \\
\hline
\end{tabular}




\begin{tabular}{|l|l|}
\hline 11A St. Joseph Street & $\begin{array}{l}\text { Designated Part IV on April 14, } 1997 \text { by By- } \\
\text { law 235-2016 }\end{array}$ \\
\hline 15 St. Joseph Street & $\begin{array}{l}\text { Designated Part IV on April 14, 1997 by By- } \\
\text { law 235-2016 }\end{array}$ \\
\hline 17 St. Joseph Street & $\begin{array}{l}\text { Designated Part IV on April 14, 1997 by By- } \\
\text { law 235-2016 }\end{array}$ \\
\hline 19 St. Joseph Street & $\begin{array}{l}\text { Designated Part IV on April 14, 1997 by By- } \\
\text { law 235-2016 }\end{array}$ \\
\hline
\end{tabular}

Table 8. Lot Size and Heritage at 606 Yonge Street. (Source: City of Toronto, 1998-2018c).

Two applications were submitted for 606 Yonge

Street, one is a Rezoning Application which was

submitted on or after January 1, 2007 and approved by

City Council on October 15, 2008; and one is a Site Plan

Approval Application which was issued on January 27,

2010. Finally, a Condominium Approval was issued on

December 19, 2014 (City of Toronto, 1998-2018a).

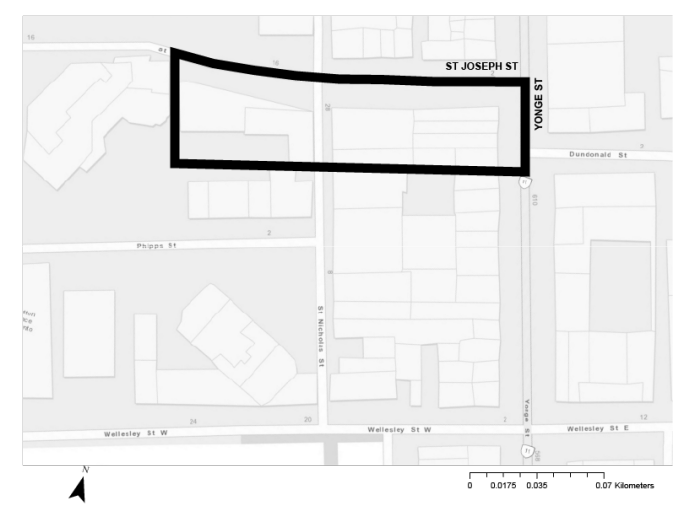

Figure 21. Location of 606 Yonge Street (Source: Anna Flood).

The site was formerly occupied by a row of six buildings that range from two to three storeys in height with frontage on Yonge Street. The property is zoned as CommercialResidential under Zoning By-law 438-86, meaning it can support a mix of commercial and residential uses. Prior to redevelopment, the buildings were occupied by commercial enterprises with no residential uses. Each of the buildings featured a commercial use on the ground floor, including a three-storey building with a restaurant and a leather store; a three-storey building with an army surplus store; a two-storey building with an internet lounge; a three-storey building with a restaurant; and a two-storey building with a restaurant. From the building at 618 Yonge Street, the frontage on St. Joseph Street included a small sandwich shop, and a patio. Vacant space formerly occupied by a sports bar took up the second floor of the building. At 5-9 St. Joseph Street, a four-storey former warehouse building was occupied by a health club on the ground floor with office uses above. At 11-19 St. Nicholas Street, a 3-storey former warehouse 
building was occupied by commercial uses. At 25 St. Nicholas Street, a six-storey former warehouse building was occupied by commercial uses. The buildings on Yonge Street were all retained as heritage properties (City of Toronto, 2009, October 19). Prior to redevelopment, nine businesses occupied the ground floor and, in one case, the second floor of these buildings (Google Maps, 2009, April). Of these nine businesses, seven (78\%) fit within the "local" category, one within the "new entrepreneurial" category (11\%) and one fit within the "corporate" category (Google Maps, 2009, July) (see Table 9).

\begin{tabular}{|l|l|c|c|c|c|}
\hline & \multicolumn{1}{|c|}{$\begin{array}{c}\text { Name of } \\
\text { Business }\end{array}$} & Local & $\begin{array}{c}\text { New } \\
\text { Entrepreneurial }\end{array}$ & Corporate & Address of Business \\
\hline 1 & $\begin{array}{l}\text { Ritz: Caribbean } \\
\text { Restaurant and } \\
\text { Bar }\end{array}$ & $\begin{array}{l}\text { A.J. Leather } \\
\text { and } \\
\text { Accessories } \\
\text { then Sky Music } \\
\text { Enterprise then } \\
\text { Sky Music } \\
\text { Enterprise }\end{array}$ & $\mathrm{X}$ & & 606 Yonge Street \\
\hline 3 & $\begin{array}{l}\text { Central } \\
\text { Surplus: Army } \\
\text { Clothing \& } \\
\text { Camping } \\
\text { Headquarter }\end{array}$ & $\mathrm{X}$ & & 608 Yonge Street \\
\hline 4 & $\begin{array}{l}\text { Iklick Internet } \\
\text { Lounge }\end{array}$ & $\mathrm{X}$ & & & \\
\hline 5 & Pizzaville & $\mathrm{X}$ & & & 612 Yonge Street \\
\hline 6 & Pita Q & $\mathrm{X}$ & & 614 Yonge Street \\
\hline 7 & Wrap \& Grab & $\mathrm{X}$ & & & 616 Yonge Street \\
\hline 8 & $\begin{array}{l}\text { Clarington's } \\
\text { Sports Bar }\end{array}$ & $\mathrm{X}$ & & & 618 Yonge Street \\
\hline 9 & L3 Fitness & $\mathrm{X}$ & & & 5 St. Joseph Street \\
\hline
\end{tabular}

Table 9. Former Businesses at 606 Yonge Street. (Source: Google Maps, 2009, July). 


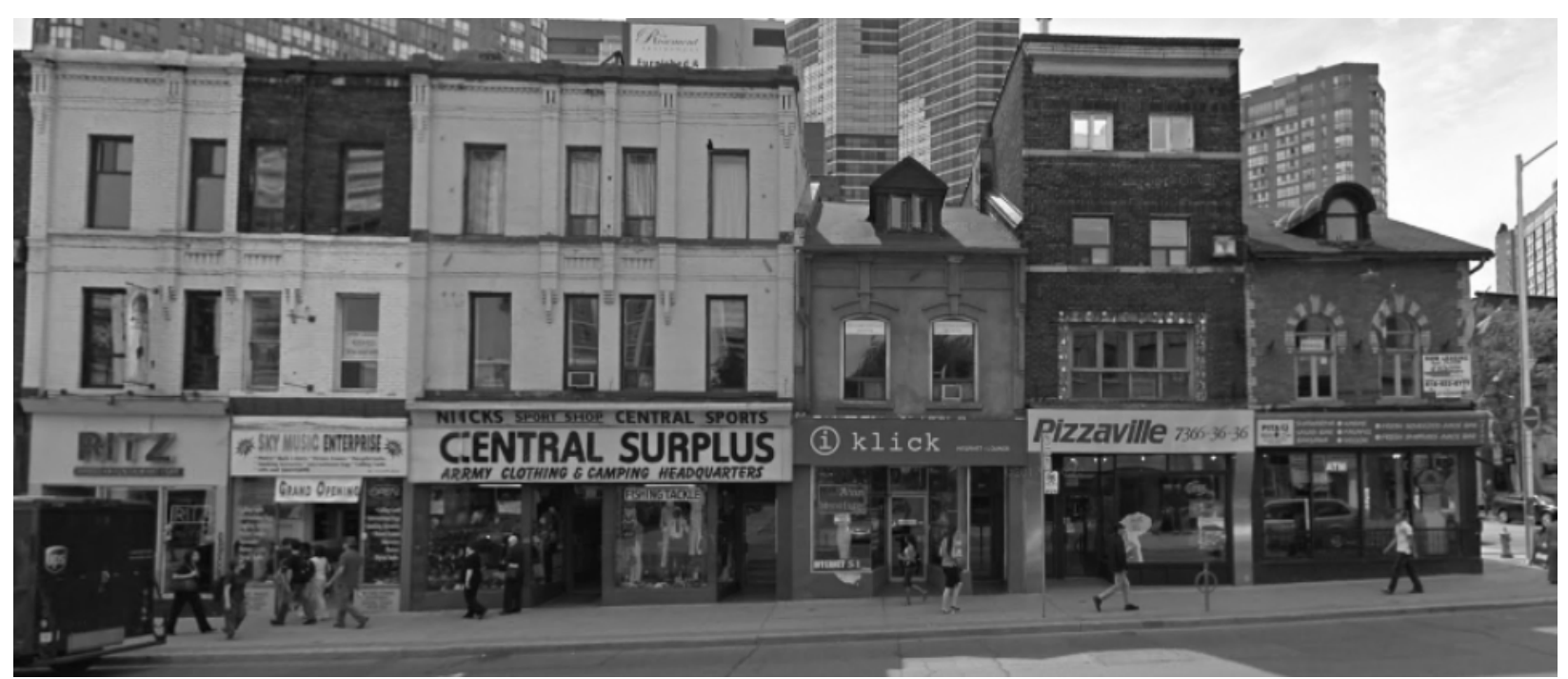

Figure 22. 606 Yonge Street prior to redevelopment in July 2009. (Source: Google Maps Street View, 2009, July).

The Rezoning Application mainly increased the height and density of the property. The site was split zoned. The zoning on the west portion of the site adjacent to St. Nicholas Street was Commercial-Residential (CR T4.0 C1.0 R4.0). The zoning on the east portion of the site adjacent to Yonge Street was Commercial-Residential (CR T3.0 C2.0 R3.0) under Zoning Bylaw 438-86. The maximum density permitted in the west was 4.0 times the lot area: 1.0 times the lot area for commercial uses and 4.0 times the lot for residential uses. The maximum density permitted in the east was 3.0 times the lot area: 2.0 times the lot area for commercial uses and 3.0 times the lot area for residential uses. The maximum height permitted was 12 metres in the west and 18 metres in the east. The ZBA allowed for a maximum density of 14.4 times the lot area and maximum height of 147 metres (City of Toronto, 2009, October 19). 


\begin{tabular}{|l|l|}
\hline \multicolumn{2}{|c|}{ The Development Application } \\
\hline Project number & $08-213136 \mathrm{STE} 27 \mathrm{OZ}$ \\
\hline Status & Constructed \\
\hline Storeys & 45 \\
\hline Total Gross Floor Area (GFA) & $39,900 \mathrm{~m}^{2}$ \\
\hline Number of Residential Units & 539 \\
\hline Residential GFA & $37,100 \mathrm{~m}^{2}(93 \%)$ \\
\hline Number of Retail Units & 3 \\
\hline Retail GFA & $2,800 \mathrm{~m}^{2}(7 \%)$ \\
\hline Density & 14.4 \\
\hline Number of Parking Spots & 270 \\
\hline
\end{tabular}

Table 10. The Development Application at 606 Yonge Street (Source: City of Toronto, 2009, October 19).

The Site Plan Approval Application and Condominium Approval allowed one mixed-use building erected at $5 \mathrm{St}$. Joseph Street that is 45 -storey or 140 metres. The tower has a 34-metres setback from the buildings on Yonge Street, an 8 metre stepback from the podium along St. Joseph Street and a 4.8-metres stepback from the podium along St. Nicholas Street. The total GFA is approximately $39,900 \mathrm{~m}^{2}$ : the residential GFA is approximately $37,100 \mathrm{~m}^{2}$ and the nonresidential GFA is approximately $2,800 \mathrm{~m}^{2}$. There are 539 residential units, including live-work units (City of Toronto, 2009, October 19). There are two retail units fronting onto Yonge Street where there had previously existed seven retail units. One unit is occupied by Royal Bank of Canada (RBC) Bank and the other unit is occupied by Aroma Espresso Bar. There is one retail unit fronting onto St. Joseph Street where there had previously existed two retail units. This unit is occupied by The Wickson Social which also has patio space to animate the street (Google Maps, 2017, August). 270 parking spaces in 5.5 levels of underground garage were proposed, which meet the minimum Zoning By-law requirement (City of Toronto, 2009, October 19). 


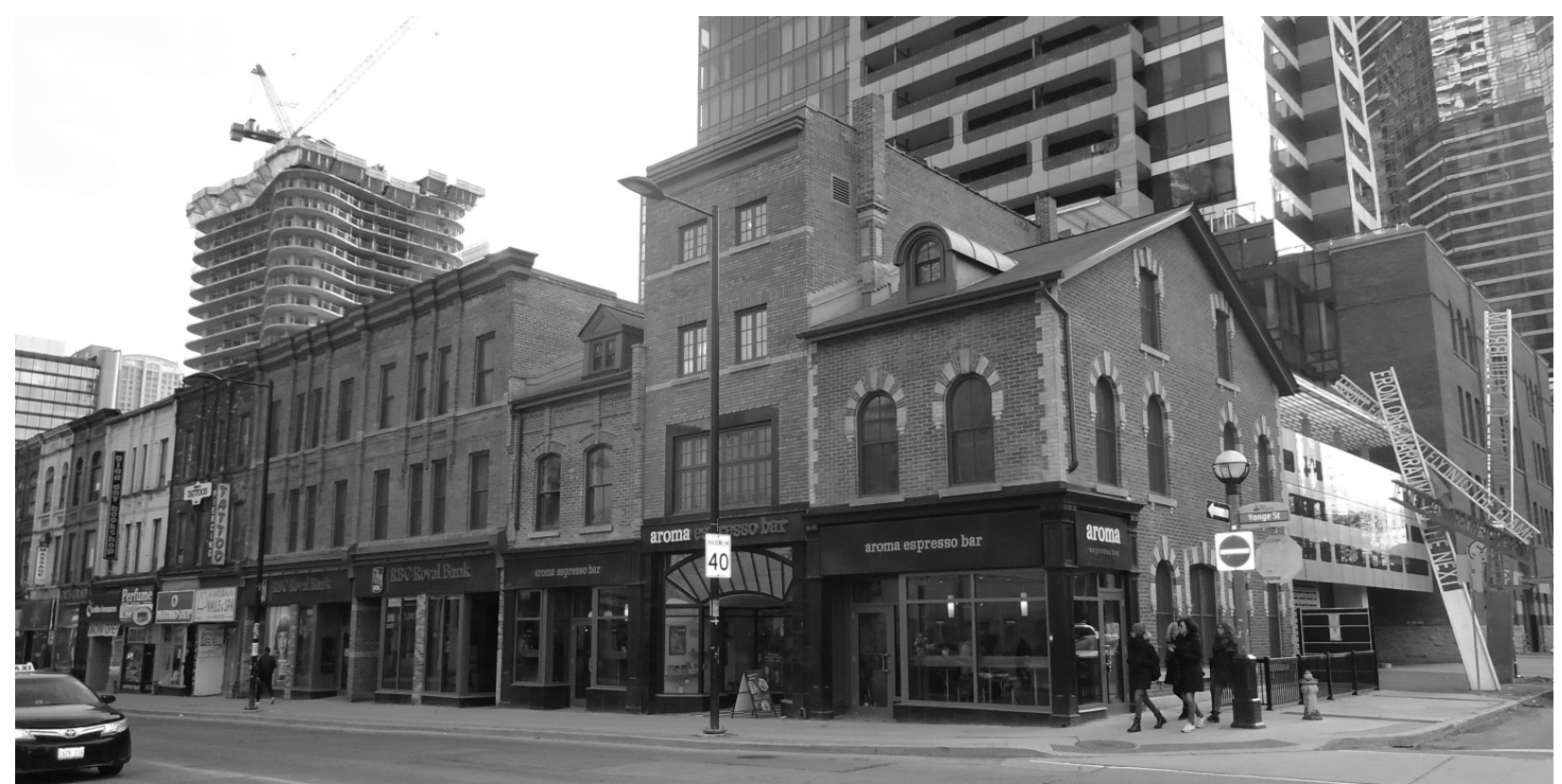

Figure 23. 606 Yonge Street following redevelopment in April 2018. (Source: Anna Flood).

The buildings at 606-608 Yonge Street, 610-612 Yonge Street, 614 Yonge Street, 616 Yonge Street and 618 Yonge Street are all designated under Part IV of the Ontario Heritage Act (1990) through the City of Toronto Heritage Register. The building at 5-9 St. Joseph Street, the Rawlinson Cartage Buildings, and the building at 11-19 St. Nicholas Street are also designated under Part IV of the Ontario Heritage Act (1990) (City of Toronto, 1998-2018c). Unlike Part V of the Ontario Heritage Act (1990), alterations to both interiors and exteriors of buildings can be controlled under Part IV (Queen's University, 1998). Although the buildings were retained in recognition of the historical architecture and character of the site, the interior of buildings fronting along Yonge Street were not protected (City of Toronto, 1998-2018c). Therefore, the developer could amass the previous seven retail units into two units, thereby, attracting two chain stores to the space.

Because this property was recently constructed in the Study Area, it acts as an indicator of the future trends in development that are occurring in the Study Area. From nine businesses that previously existed on the site, there are now three businesses. RBC Bank, a national chain, 
now occupies the retail space at 608 Yonge Street. Aroma Espresso Bar, an international chain with roots in Israel (Aroma Espresso Bar, 2016), now occupies the retail space at 618 Yonge Street (Google Maps, 2017, August). The size of the retail units fronting onto Yonge Street is larger than the traditional floorplates of the Study Area. The development project maintained the same number of retail entrances and bays fronting onto Yonge Street. However, the decrease in the number of businesses which occupy the buildings does not help to animate the street. The Wickson Social, an upscale and trendy restaurant and bar, has taken over the commercial space at 5 St. Joseph Street (Google Maps, 2017, August). Meanwhile, the residential gross floor area has increased from $0 \mathrm{~m}^{2}$ to $37,100 \mathrm{~m}^{2}$. Of the total gross floor area of $39,900 \mathrm{~m}^{2}$, the new development sees $93 \%$ of the use as residential and $7 \%$ of the use as retail (City of Toronto, 2009, October 19).

\section{Analysis}

Overall, the height and density of the properties have increased dramatically through rezoning applications in all three development projects. While it is appropriate to direct high density toward major arterial streets that are well-serviced by transit and community amenities, it is creating unintended consequences for Downtown Yonge Street. Higher height and density are generating higher property values which in turn have begun to encourage land assembly.

Developers are purchasing adjacent properties and proposing the total demolition of buildings, or the consolidation of the ground floors of buildings, to attract chains as potential anchor tenants. This allows developers the ability to create the structural base that supports the development of high-rise towers above. The ground floors may retain retail uses, but the retail spaces tend to be larger to support the format of chains rather than small businesses. This is evidenced by the development project at 606 Yonge Street, the total number of retail units decreased to three retail 
units as a result of amassing of previously adjacent nine retail units. By creating fewer but larger retail units, the development project at 606 Yonge Street has proved the literature to be true in that this form of development attracts national and international chain stores and restaurants, displacing the local businesses which previously occupied the site. Where nine retail units previously existed, three retail units have taken their place, two corporate businesses and one new entrepreneurial business.

The most recent ground floor architectural plans and the zoning by-law amendment for the development project at 480 Yonge Street also indicate that the number of retail units will be decreasing from 12 units to three units and the size of the retail floorplates will be larger than traditional retail in the Study Area. From this pattern of development, one might deduce that the retail trend may apply to the properties at 501 Yonge Street where 19 businesses were displaced. Certainly, by diminishing the number of retail units that are available and increasing the square metres of retail units, many local businesses will be displaced from the Study Area because owners will likely be unable to afford the cost of leasing the new, larger retail units.

Yonge Street is a mixed-use neighbourhood. It is characterized by retail on the ground floor and affordable residential and office spaces above. With the introduction of significantly denser residential uses, which are largely luxury condominiums, property values are increasing. Retail spaces are becoming higher-value spaces per square metre and they are increasing in the number of square metres. Property taxes for the newly assessed property values are being paid by business owners either directly as property owners or indirectly as tenants. With the introduction of high-rise and high-priced luxury condominium buildings, the cost per square metre of leasing retail space is increasing dramatically. Where minimal or no residential use had previously existed on the sites of each of the three development projects, the number of residential uses far 
outweighs the usual typology. Residential use comprises over $90 \%$ of the buildings' use. At 501 Yonge Street, the development is 98\% residential and at both 480 Yonge Street and 606 Yonge Street, it is $93 \%$ residential.

Heritage buildings and facades are being maintained to retain the traditional character of the street. As evidenced by the projects at 480 Yonge Street and 606 Yonge Street, the City has applied heritage designations to most of the buildings which are significant to the Study Area. Buildings that are not original to the area are being replaced with new high-rises towers such as the property at 501 Yonge Street and the property at 490 and 492-494 Yonge Street and 3 Grosvenor Street. Where buildings are designated, the City is the approval authority for heritage permits for alterations. Where buildings are listed, there is much less protection than when they are designated. The property at 490 Yonge Street demonstrates this as the property was found to no longer retain heritage value and was demolished to allow for the base of the tower at 480-494 Yonge Street. Even with the requirement of narrower retail frontage and multiple retail entrances/bays, the original streetscape animation and neighbourhood character are lost amid small business closures and international chain openings.

Although high-rise condominium buildings with heritage facades may appear unchanged from the exterior, the historic integrity of the buildings' interior need not be preserved. In the Province of Ontario, there are only legal protections for the historic integrity of the interiors of heritage buildings under Part IV of the Ontario Heritage Act (1990). However, it is rare that the interiors of heritage buildings be preserved. In the case of 606 Yonge Street, the interior walls were demolished to create the spaces that most attract what developers perceive as stable, longterm tenants, chain stores. This also appears to be the case at 480 Yonge Street. 


\section{CITY OF TORONTO RESPONSES TO COMMERCIAL GENTRIFICATION IN DOWNTOWN YONGE STREET}

The character of Downtown Yonge Street will depend on animating the retail streetscape of the neighbourhood. New development must be sensitive to the cultural and historic context. The following City of Toronto policies help to protect and conserve small-scale retail and the heritage and character of the Downtown Yonge Street neighbourhood.

\section{Ontario Heritage Act (1990)}

There are 120 properties that are either listed on the City of Toronto Heritage Register or designated by the City of Toronto under Part IV of the Ontario Heritage Act (1990). The City's Heritage Register must be conserved and maintained consistent with the Standards and Guidelines for the Conservation of Historic Places in Canada (Ontario, 1990).

\section{City of Toronto Historic Yonge Street Heritage Conservation District Plan (2016)}

Toronto City Council enacted By-law 235-2016 that designated the Historic Yonge Street Heritage Conservation District (HCD) (2016) under Part V of the Ontario Heritage Act (1990) on March 10, 2016. The designation applied to almost all properties that front onto Yonge Street between Bloor Street to the north and College/Carlton Street to the south. The By-law adopts the Historic Yonge Street Heritage Conservation District Plan from January 2016. A HCD provides the framework to conserve the character of a district as defined by its historical context, architecture, streets, landscape, and other physical and visual features. The following sections are relevant to retail in the Study Area (City of Toronto, 2016a):

5.9.1 Commercial storefronts must not be taller than one storey at grade (approximately 4.5 metres). Operable doors should be retained where they exist.

5.9.2 Commercial retail activity that is at-grade and accessible from the public realm is an importance aspect of the character and should continue to be accommodated. 
5.9.3 At-grade access to retail spaces and upper floors from Yonge Street is strongly encouraged.

5.9.4 6.5.2 Design new development to provide retail bays of between 3 and 7 metres wide (ideally 4.5 metres) along streets that are appropriate.

\section{City of Toronto Tall Building Design Guidelines (2013)}

In May 2013, the Tall Building Design Guidelines (2013) were adopted. The guidelines are to be used in evaluating all new and current tall building development applications. They include performance measures that evaluate tall building proposals to ensure that they fit within the context of the surrounding area and minimize their impact on the surrounding area. This policy is bounded by Bathurst Street, Lake Ontario, the Don River, Rosedale Valley Road and the CPR Track. It establishes minimum setbacks for tall buildings specifically the tower portion of the buildings. It also provides for the separation between buildings. Yonge Street is identified as a Special Character Street due to the studies in the North Downtown Yonge Street Area Specific Policy No. 382 and the Historic Yonge Street Heritage Conservation Direct Plan. It is intended to recognize that tall buildings may be suitable if there is appropriate lot configuration, context, and an acceptable heritage preservation strategy. The guidelines specify that there be a minimum tower set-back of 20 metres from the existing street wall facing Yonge Street for sites that include a heritage property. Tower heights are determined on a site-specific basis (City of Toronto, 2013c).

North Downtown Yonge Area Specific Policy No. 382 and Urban Design Guidelines (2013)

The area of Yonge Street between College/Carleton Street to the south and Charles Street to the north, and Bay Street to the east and Church Street to the south is subject to the North Downtown Yonge Area Specific Policy No. 382, Official Plan Amendment No.183, and North Downtown Yonge Urban Design Guidelines. Part of the Study Area is within the Yonge Street 
Character Area. The guidelines indicate that the area has a strong heritage fabric and have introduced several guidelines to respect the heritage of the area. These include narrow retail frontages and multiple retail entrances, recognizing Yonge Street as a priority retail street which should be lined with grade-related uses to promote a safe and animated pedestrian environment (City of Toronto, 2013a).

\section{Property Tax Amendments}

Property values of the historic low-rise buildings that characterize Yonge Street have been recently assessed against the new high-rise buildings being introduced into the Study Area. In 2017, property taxes skyrocketed. Commercial businesses, that have long occupied the ground floor of buildings, have received property tax bills as high as double those from past assessments. Due to unaffordable property tax bills, some small business owners were forced to close and vacate their properties (Mitchell, 2017). Higher rates of homeowner foreclosures and investor foreclosures can lead to homeowner and tenant evictions (Maeckelbergh, 2012).

Assessments of commercial properties are rising as the prices of residential properties are increasing in cities. Assessments are based on the potential highest and best use of a property although the highest and best use does not necessarily reflect the current use of a property. Thus, property tax bills may not mirror the income that a commercial property is earning. Small businesses may pay more per square foot in property taxes than high-rise condominiums. This is certainly the case for small businesses in Downtown Yonge Street which are struggling to survive amid condominium developments (Klingbeil, 2017, June 6). Following Vancouver, Toronto has one of the highest property tax rates for commercial properties in Canada. In 2017, the commercial-to-residential property tax ratio was 3.81 in Toronto. This ratio compares the commercial tax rate and the residential tax rate, meaning the commercial tax rate was 3.81 times 
the residential rate. Commercial properties incurred property taxes that were 3.81 times higher than equally valued residential properties (Altus Group Limited, 2017). With the main street changing, business owners often lease and do not own the buildings. The tradition of business owners using the ground floor to house their businesses and the upper floors to live is disappearing, eliminating capital assets and leaving only operating costs for businesses (Klingbeil, 2017, June 6).

In Toronto, a new class of commercial property tax has recently been proposed; one that would address equity issues for culture and creative properties. Trinity-Spadina MPP Han Dong explains that the new property tax class will be somewhere "between residential and commercial" because "the Province does not want our cultural community feeling crushed by tax burdens." This conversation between the Province and the City was inspired by stakeholders, including Margie Zeidler, owner of 401 Richmond, a former industrial building that houses an array of businesses, charities, artist studios and galleries in Toronto (CBC News, 2017, September 26).

Unfortunately, the culture and creative property tax class would not apply to small businesses on Yonge Street so the City is advocating for property tax reforms that will introduce a small business or low-rise building property tax classification. This new property tax class would change the way that these properties are currently assessed by MPAC (Pelley, 2017, August 18). Before this property tax class can be brought into effect certain questions must be addressed. How do you define a small business? Who will fit within this new class? Who will not? (Klingbeil, 2017, October 31). In the meantime, several small businesses on Yonge Street have successfully applied to MPAC to have their properties reassessed, reducing their property tax bills. The City has also implemented tax capping policies for the 2018 taxation year. Tax 
increases for the commercial, industrial, and multi-residential property classes have been limited to $10 \%$ of the previous year's annualized taxes (City of Toronto, 2018, January 16).

Although these initiatives are certainly progressive and helpful in the short-term, it would be a valuable exercise to explore other potential sources of municipal revenue given the obvious difficulties that this property tax system presents. One option is a split assessment which allows the space on top of a commercial unit to be taxed at the residential rate, which is lower than the commercial rate. Alternatively, a three or five-year average allows the tax base to be calculated based on the property value over a period of three to five years. Tax credits for landlords can also incentivize them to provide affordable rents to their tenants (Ma, 2018, January 13). For example, in New York City, the Lower Manhattan Commercial Revitalization Program and companion Commercial Rent Tax Special Reduction Program offer a property tax abatement and rental tax reduction (LaVecchia \& Mitchell, 2016). 


\section{CASE STUDIES: MUNICIPALITIES' RESPONSES TO COMMERCIAL GENTRIFICATION}

The City of Toronto has created policies to help mitigate the negative impact of development pressures on the character and history of Downtown Yonge Street and its unique position as a retail district. Among these are the Ontario Heritage Act (1990), Historic Yonge Street Heritage Conservation District Plan (2016), the North Downtown Yonge Area Specific Policy No. 382 and Urban Design Guidelines (2013), the Downtown Tall Buildings Set Back Area Specific Policy No. 352 and Urban Design Guidelines (2013), and the 10\% tax cap (City of Toronto, 2018, January 16) which are key. They do not, however, go far enough. The following statement from Zukin (2010) perfectly describes this gap in policy.

Today city planners swear loyalty to Jane Jacob's vision. Her goal of preserving the city's physical fabric by maintaining the small scale and interactive social life of the streets has been translated into laws for preserving much of the building environment. But these laws go only part of the way toward creating the vibrant city that Jacobs loved. They encourage mixed uses, but not a mixed population. They never speak of maintaining low rents on commercial properties, so they cannot combat the most common means of uprooting the small shop owners who inspired Jacob's idea about social order and the vitality of the street. More and more of the owners, in any case, are chains; there are few traditional shopkeepers left. The city government has overturned communities plans for low-key, mixed development that place a priority on maintaining existing tenants and uses, and responds with "affordable" units only if a community rises up in protest... (p. 25).

How can the City of Toronto and other municipalities that are experiencing similar issues

better protect the character and heritage of their neighbourhoods and support their local businesses? This chapter will explore planning and policy mechanisms that have been successfully implemented in other North American municipalities.

\section{Zoning}

Zoning is one of the most powerful tools that municipal governments possess and can be employed to shape a city (LaVecchia \& Mitchell, 2016). Zoning can preserve the supply of 
smaller retail spaces and discourage large storefronts, thereby, discouraging the proliferation of chain stores which often do not work with small scale formats. The City of Toronto has regulated the width of storefronts on the ground level of buildings through the North Downtown Yonge Area Specific Policy No. 382 and the associated Urban Design Guidelines. The policy limits the width of new storefronts from five to seven metres depending on the block of Yonge Street. The provision has been captured in zoning by-law amendments on a site-specific basis. The By-law No. 139-2014 for the development project at 501 Yonge Street included a requirement that the owner shall design, construct and thereafter maintain "A maximum retail expression for ground floor retail unit facades along the lot's Yonge Street frontage of 5.0 metres (+/- 0.25 metres) intervals" (City of Toronto, 2014, February 20, p. 12). The policy and guidelines were enacted after the Zoning Review for 606 Yonge Street had been conducted. They were appealed to the Ontario Municipal Board (OMB) during the Zoning Review for 480 Yonge Street. Although the final staff report recommends that the retail frontage be divided into multiple bays with widths of approximately nine metres, this requirement was not included in By-laws No. 1264-2017 or 1263-2017 (City of Toronto, 2017, November 9a; City of Toronto, 2017, November 9b).

New York City has zoning regulations to regulate the width of new storefronts at street level which limit the storefronts of banks to 25 -feet and general storefronts to 40 -feet along certain corridors on the Upper West Side. This applies, generally, from $72^{\text {nd }}$ to $110^{\text {th }}$ Street on Broadway and Amsterdam and from $72^{\text {nd }}$ to $87^{\text {th }}$ Street on Columbus (Goodyear, 2016, April 5).

The Historic Yonge Street Heritage Conservation Plan (2016) does not regulate the internal design of a building or retail unit. Therefore, it recommends that “ $\ldots$ the City investigate additional planning mechanisms to support fine grain independent retail, including, but not limited to, regulating the floor plate of retail spaces" (City of Toronto, 2016a, p. 64). 


\section{Community Benefits of Agreements}

The City of Toronto has the power to leverage facilities, services, and matters to be provided to the City at the owner's expense in accordance with zoning by-law amendments and further specified in community benefit agreements pursuant to s. 37 of the Ontario Planning Act (1990). In exchange for ZBAs, typically for increased height and density, the City can negotiate these facilities, services, and matters. Space for small businesses was not a part of the s. 37 provisions for any of the three development projects. However, this could be a powerful tool to negotiate space for small businesses in new development projects. In the West Harlem neighbourhood of New York City, the West Harlem Community Benefits Agreement (2009, May 18) included 12,000 GSF of small format retail space for local entrepreneurs and existing local businesses in addition to an additional 6,000 GSF in the project area for local residents and existing businesses within CD9.

\section{Retail Curation}

The City of Toronto is considering a potential retail strategy. In early 2017, City Council passed a motion, MM27.36, requesting that the Chief Planner and Executive Director, City Planning, in consultation with the General Manager, Economic Development and Culture, report to the Planning and Growth Management Committee in the fourth quarter of 2017 on an approach to a potential retail strategy that:

- Ensures new retail uses better address the goals and objectives of the Official Plan;

- Evaluates similar policies in other cities, including, but not limited to, the 2006 Formula Retail Strategy in San Francisco; and

- Promotes flexibility and incentivizes variation in both the size and type of new retail spaces on commercial streets (City of Toronto, 2017, March 28). 
In San Francisco, the Formula Retail Strategy (2006) requires that formula businesses, those businesses that have more than 11 locations globally, must apply for a special use permit to locate in any of the neighbourhood commercial districts in the city (LaVecchia \& Mitchell, 2016). The Strategy promotes flexibility and incentivizes variation in both the size and type of new retail spaces on commercial streets. A business diversity ordinance can ensure that independent, neighbourhood-servicing businesses are not displaced by chains. California, Maine, and Maryland also have ordinances that were implemented to regulate the size and minimize the number of "formula business" or, in other words, chain stores (Sutton, 2010). However, the Formula Retail Strategy in San Francisco is one of the most comprehensive (LaVecchia \& Mitchell, 2016).

\section{Historic Preservation}

The Ontario Heritage Act (1990) governs the powers that the City of Toronto and other municipalities in the province can exercise to promote the conservation and preservation of historically and culturally significant properties. Prioritizing historic preservation can also help to diversify the mix of buildings. In Phoenix, the Adaptive Reuse Program offers development guidance, streamlined processes, reduced timelines and cost savings for certain projects (City of Phoenix, 2018). Projects under 5,000 $\mathrm{ft}^{2}$ are eligible for additional incentives (City of Phoenix, n.d.).

In San Francisco, a Legacy Business Registry exists as an inventory of the city's historic businesses. The inventory includes businesses which are 30 years or older and contribute to the identity of the city, and businesses which are as young as 20 years old but meet other criteria. Once a business is added to the Legacy Business Registry, it is eligible for a grant of $\$ 500$ per employee with a cap of $\$ 50,000$ on an annual basis. Property owners who extend 10 -year leases 
to these businesses are eligible for $\$ 4.50 \mathrm{f}^{2}$ with a cap of $\$ 22,500$ annually (LaVecchia \& Mitchell, 2016).

\section{Create a Preference for Local Businesses in Publicly-Owned Buildings, and Vacant and Under-Utilized Buildings}

Municipalities can set aside space for local businesses publicly-owned buildings. In Seattle, the King Street Station needed commercial tenants for the shops inside the station and the plaza outside of the station. The City sought out local businesses for the spaces, and reviewed different types of lease structures that would be favourable to local businesses. These lease structures included flexible lengths, options to extend, assistance with space improvements and additions, and gradual rent increases. In Anchorage, a land trust partners with small business owners to repurpose vacant commercial buildings (LaVecchia \& Mitchell, 2016). In Toronto, the Parkdale Neighbourhood Land Trust acquires land in the gentrifying neighbourhood and leases it to non-profit partners who provide space for social enterprises and affordable housing among other community-building initiatives (Parkdale Neighbourhood Land Trust, n.d.). In Boston, the City's Small Business Plan (2016) stipulates that businesses in priority segments; and minority, female and/or immigrant business owners will be given priority as commercial tenants in underutilized properties (LaVecchia \& Mitchell, 2016).

If the City of Toronto sets a precedent for a successful partnership with small businesses as commercial tenants, private property owners will be encouraged to extend leases to small businesses. Cities can require that a part of the retail space on the ground floor of new developments be available for ownership. This type of action has been enacted in development projects on a site-specific basis in Austin and Minneapolis among other American cities (LaVecchia \& Mitchell, 2016). 


\section{Provide Affordable Commercial Space through Mission-Driven Entities}

Calkins et al. (2014) explores the potential of providing affordable commercial space through mission-driven entities, such as community land trusts; community development corporations, and public development authorities. The authors also explore models and strategies for leasing commercial space in detail, including shared equity, master lessor, business incubator, and lease-to-own.

The interests of the mission-driven entities may be more aligned with those of the commercial tenants than traditional lenders or landlords. This may be reflected in the lease terms that are extended to small businesses. The City could also encourage these types of partnerships by offering tax credits for local investments (LaVecchia \& Mitchell, 2016).

\section{Commercial Tenant Protections}

Affordable commercial rents are crucial to keeping small businesses at the neighbourhood level (Zukin, 2011). The Ontario Commercial Tenancies Act (1990) does not provide the same rights to tenants as does the Ontario Residential Tenancies Act (2006). The Commercial Tenancies Act (1990) does not regulate rent increases for businesses. While leases outline the amount of rent and the frequency of rent increases, the landlord may increase the rent by any amount, at any time, outside of these details being agreed upon. Rent control would provide more stability to commercial tenants as would eviction protections and lease negotiation rights similar to those set out in the Residential Tenancies Act (2006).

As per the Commercial Tenancies Act (1990), on the $16^{\text {th }}$ day after the day that rent is due, the landlord can either change the locks without notification or seize the tenant's property with notification of intent to dispose of it. The Residential Tenancies Act (2006) allows tenants to appeal the eviction at a hearing by the Landlord Tenant Board or to pay the rent owed in addition 
to any fees incurred by the landlord. Under the Residential Tenancies Act (2006), the landlord can evict the tenant only for a select number of reasons with varying terms of notice. In cases where a tenant is evicted due to demolition of the building or conversion of the building to another use, the landlord must provide 120 days' written notice. A landlord must provide the tenant with compensation equal to three months' rent or the offer of another rental unit that is acceptable to the tenant. If a building is being repaired or renovated, the tenant must be able to move back into the rental unit at the same rent as before the tenancy was terminated. If the tenant chooses not to move back into the rental unit after the repairs or renovation are complete, the landlord must pay the tenant an amount equal to three months' rent or offer another rental unit that is acceptable to the tenant. This creates more stability to residential tenants than commercial tenants.

In the case of leases governed under the Commercial Tenancies Act (1990), month-tomonth tenancies allow the landlord to terminate a lease with one-month's written notice. Fixedterm tenancies mean the tenant no longer has the right to occupy the premises once the tenancy ends. If they continue to occupy the premises after being asked to move, the landlord can implement a penalty of two months' rent for each month that the tenant remains with applicable costs. The Residential Tenancies Act (2006) automatically renews a 12-month lease on a monthto-month basis until a tenant provides two months' notice.

New York City has unsuccessfully tried to enact the Small Business Jobs Survival Act for over 30 years due to political barriers. The Act's objective is to provide commercial tenants with rights in terms of lease renewals, such as a timeline for lease negotiations, and 10-year leases with renewal options and binding arbitration in instances of disputes (LaVecchia \& Mitchell, 2016). 


\section{Tax Alleviation Schemes}

In the City of Toronto, Council adopted the creative co-location facilities subclass within the commercial residual property class and industrial property class for the 2018 taxation year on February 12,2018 . It was set at a 50 percent reduction of the commercial residual property class tax rate and the industrial property class tax rate. However, it is subject to the required regulation being enacted by the Province (City of Toronto, 2018, February 12). Such a class would be beneficial for small businesses and/or low-rise buildings. Reducing the property tax assessments and rate for commercial or otherwise classes is helpful for small businesses in the short-term.

Taxes on land and property exist everywhere; however, they are only a significant source of revenue for relatively few countries, mainly countries that are developed and of British tradition (Bird \& Slack, 2007). Property tax is considered an important source of municipal revenue in five of 27 Organisation for Economic Co-operation and Development (OECD) countries, including Canada, whereas other taxes, such as income, corporate and personal taxes are considered important sources of local tax revenue for 13 of 27 OECD countries. In other countries, cities impose income tax at a flat rate from one to five percent. In Canada, municipal governments have no access to income tax. In other countries, business tax is implemented. In Canada, municipalities have moved away from business tax in favour of commercial property tax. In other countries, local sales tax generates an important source of municipal revenue by levying retail rather than wholesale purchases. In Ontario, sales tax is not local; it is a harmonized tax where a portion is charged by the provincial government and by the federal government (Kitchen, 2003). 
In addition to income, corporate and personal taxes, Bird and Slack (2007) discuss other sources of revenue that can be used by municipalities, such as payroll taxes and vehicle and fuel taxes in addition to the significance of user charges and intergovernmental transfers.

\section{Vacant Commercial Properties Tax}

The City of Toronto is planning to discontinue the vacant commercial and industrial unit tax rebate on July 1, 2018. This program offered a rebate to commercial and industrial buildings which were partially vacant for at least 90 consecutive days. From January 1 to June 30, 2017, the commercial rebate was $30 \%$ and the industrial rebate was 35\% (City of Toronto, 2018). Another approach is observed in San Francisco where Ordinance No. 182-14 conversely requires that any partially vacant commercial storefront register with the City and pay an annual fee of \$711 (City of San Francisco, 2014, July 22).

\section{Civic Stewardship}

Outside of planning and policy considerations, one of the most important tools to mitigating the displacement of small business is through a community coalition of neighbourhood businesses, local residents, and organizations. In a community coalition, members can assess community needs and assets; set goals; prioritize the community and its long-term residents; and enforce government policies. In enforcing government policies, the community coalition can voice concern about zoning codes and their compatibility with the community's goals to protect the valuable parts of the community and set aside areas for affordable commercial spaces and housing (Great Communities Collaborative, 2007).

In Downtown Yonge Street, planners and policy-makers should explore the potential of business associations or other networks where small business owners can engage in the organization's mission and operations; the delivery of support services; and participate in 
political activities. By raising capital beyond membership dues from external sources, business associations can meet their mandate to support the small business owners which make up their membership. Business associations can also help build capacity among small business owners by providing them with information regarding regulations, norms, practices, and politics in daily business operations. They can also create campaigns that encourage consumers to "buy local". Small business owners can explore cooperative options, such as bartering of services and goods, sharing of employees, and developing incubator models. Together, they can curate a collective voice to assert in the planning and decision-making process at the neighbourhood and, even, municipal level (Sutton, 2010).

The community coalitions and business associations described in the literature are similar to the framework of Business Improvement Areas (BIAs) in Ontario. A BIA does not currently exist within the Study Area (City of Toronto, 2016c). The nearest BIA is the Downtown Yonge Business Improvement Area (DYBIA). Currently, the DYBIA boundaries encompass Yonge Street from Richmond Street to the south to Grosvenor Street to the north (Downtown Yonge Business Improvement Area, n.d.).

DYBIA is actively involved in the Downtown Yonge neighbourhood with decision makers who empower businesses and make it easier for them to organize. As a non-profit organization, its vision is a world leading downtown neighbourhood renowned for its culture, commerce, opportunity, and liveability. Its mission is to strengthen the culture and economy of the Downtown Yonge neighbourhood through collaborative leadership, and transformative experiences, and investments (DYBIA, 2017-2022). One of its strategic initiatives includes an objective to "Facilitate and provide appropriate tools for members, partners and stakeholders on street-level issues, building relationships and connections between members and key 
stakeholders" (DYBIA, 2017-2022, p. 26). Another of its strategic initiatives is to encourage a Downtown Yonge Street that is economically strong with the goal, "To support a best in class destination that features a range of opportunities and experiences, and bolsters Toronto's economy" (DYBIA, 2017-2022, p.27). Their strategy aims to, "Drive demand in the neighbourhood economy through events, street animations, and other initiatives that engage people throughout the year" (DYBIA, 2017-2022, p. 30). To achieve this strategic initiative, DYBIA commits to providing advocacy, reporting, market analysis, development leadership, revenue sources, event production, and market intelligence. Like the community-building literature, DYBIA advocates on policy and regulations for its membership. It provides leadership and guidance during the development process to align with the vision of its membership. DYBIA also develops revenue sources for operational use external to its membership dues through sponsorship cultivation. (DYBIA, 2017-2022).

The City of Toronto offers a wide variety of services for small businesses in the city, including the Toronto Business Development Centre (2018), Enterprise Toronto (City of Toronto, 1998-2018d), the Business Connect publication (City of Toronto, 2015) and the City's Economic Development Team (City of Toronto, 1998-2018e). However, there is currently no comprehensive approach to help support small businesses in the city. Boston provides an example of how Toronto might support small businesses in the Downtown Yonge Street neighbourhood. The City of Boston has adopted a five-year Small Business Plan (2016) to help businesses start and grow in Boston. The Plan was developed by engaging with public, private, and civic stakeholders. This collaborative approach helped to identify strategies to increase equitable opportunities for existing and new entrepreneurs across Boston. It also helped to determine how the City could implement these strategies (City of Boston, 2016). 


\section{REFLECTIONS, LESSONS, AND RECOMMENDATIONS}

\section{Zoning}

It is recommended that the City maintain appropriately-sized retail space for small businesses in every new development project by regulating the floor plates of retail units in the Study Area. Smaller floor plates are more conducive to the operations of smaller businesses. They are also more traditional of the Study Area's historic building interiors and retail units. Currently the regulation of floor plates of retail units on the ground floor of buildings has happened through zoning by-law amendments on a case-specific basis, such as the development project at 480 Yonge Street. However, it is recommended that the total interior floor area of all retail services on the ground floor of buildings be regulated such that they may not exceed the size of traditional retail units for all lands zoned Commercial Residential within the Study Area. Therefore, it is recommended that Zoning By-Law 438-86 and Zoning By-Law 569 be amended to reflect this change in the next zoning by-law review. Local retail on the ground floor of buildings in Downtown Yonge Street will ensure that it continues to be a priority retail destination.

\section{Community Benefit Agreements}

It is recommended that the City reserve a certain amount of retail space on the ground floor of every new development project for locally-owned, small businesses through Community Benefits Agreements in the Downtown Yonge Street. The owners of new development projects enter Agreements where developers provide community benefits in exchange for greater density and height in their projects. In Ontario, Agreements are pursuant to Section 37 of the Planning Act (1990) as satisfactory to the City Solicitor, and the Chief Planner and Executive Director of City Planning. For Downtown Yonge Street, Agreements could stipulate that a part of the retail 
space on the ground floor of new development projects be available to small businesses for ownership or lease.

\section{Retail Curation}

It is recommended that the City continue to consider an approach to a retail strategy for the Study Area that evaluates similar policies in other cities, including, but not limited to, the Formula Retail Strategy (2006) in San Francisco. The City would need to establish legislation that is based on a specific zoning district for the neighbourhood which would also need to be established. After defining formula retail, either a Conditional Use authorization for formula retail or a prohibition on formula retail would be created (City of San Francisco Planning Department, 2014).

\section{Historic Preservation}

It is recommended that the City consider city-wide programs, such as, but not limited to the Adaptive Reuse Program in Phoenix. The City could offer development guidance, streamlined processes, reduced timelines and cost savings for certain adaptive reuse projects to encourage historic preservation (City of Phoenix, 2018).

It is recommended that the City evaluate existing policies to provide capital to small businesses, including, but not limited to, San Francisco’s Legacy Business Registry which provides $\$ 500$ per employee (up to $\$ 50,000$ ) for eligible businesses; and $\$ 450$ per square foot (up to $\$ 22,500$ ) for property owners, that agree to offer 10 -year leases to those businesses on an annual basis (LaVecchia \& Mitchell, 2016).

\section{Create a Preference for Local Businesses in Publicly-Owned Buildings, and Vacant and Under-Utilized Buildings}

It is recommended that the City set aside space for small businesses in publicly-owned buildings, similar to Seattle's King Street Station. Incorporating local businesses into municipal 
buildings would provide the City with the opportunity to test a range of lease types that are potentially more favourable for small businesses. The types of businesses that the City chooses to lease to can simultaneously align with other municipal goals (LaVecchia \& Mitchell, 2016). By setting the precedent for a successful partnership with small businesses, private owners will be encouraged to extend leases to small businesses in their own buildings.

It is recommended that the City of Toronto partner with organizations, such as land trusts, that are seeking to work with small businesses to find commercial space in under-utilized or vacant buildings.

It is recommended that the City set aside space for small businesses in under-utilized publicly-owned buildings by making it a priority through a small business plan, such as Boston's Small Business Plan (City of Boston, 2016).

It is recommended that the City match vacant, under-utilized, and publicly-owned space with small business owners who are interested in traditional leases as well as pop-ups, subleases, shared equity, master lessor, business incubators, lease-to-own, or other leasing models (Calkins et al., 2014).

\section{Provide Affordable Commercial Space through Mission-Driven Entities}

It is recommended that the City explore the potential for partnerships between small businesses seeking commercial spaces in the neighbourhood and community land trusts, community development corporations, and public development authorities. The exploration of different types of lease structures between small businesses and these types of mission-driven entities is encouraged (Calkins et al., 2014). It is also recommended that the City offer tax credits to mission-driven entities (LaVecchia \& Mitchell, 2016). 
It is recommended that the City build a network of public and private sector property owners and managers, brokers, and other experts to provide ongoing information about commercial space to small businesses that are seeking commercial space (City of Boston, 2016).

It is recommended that the City consider developing a tool that shows listings for vacant commercial space in the neighbourhood (City of Boston, 2016).

\section{Commercial Tenant Protections}

Like the proposed Small Business Jobs Survival Act in the City of New York, it is recommended that the Province introduce a new Act or amend the Commercial Tenancies Act (1990) to better regulate rent increases, evictions and lease renewal negotiations. These protections would provide greater stability to commercial tenants (LaVecchia \& Mitchell, 2016).

Like the Ontario Residential Tenancies Act (2006), it is recommended that a rent increase guideline for commercial properties be established and applied 12 months after the last rent increase or when a tenant first moves in. Commercial tenants must be given written notice of a rent increase at least 90 days before it takes effect. Like the Ontario Residential Tenancies Act (1990), the rent increase could be calculated using the Ontario Consumer Price Index, a Statistics Canada tool that measures inflation and economic conditions over the period of one year (Ontario, 2018).

Like the Ontario Residential Tenancies Act (2006), it is recommended that commercial tenants must be given 120 days' written notice if a landlord decides to demolish a building or convert the use of a building to another use. A landlord must provide the tenant with compensation equal to three months' rent or the offer of another rental unit that is acceptable to the tenant. If a building is being repaired or renovated, the tenant must be able to move back into the rental unit at the same rent as before the tenancy was terminated. If the tenant chooses not to 
move back into the rental unit after the repairs or renovations are complete, the landlord must pay the tenant an amount equal to three months' rent or offer another rental unit that is acceptable to the tenant.

Like the Ontario Residential Tenancies Act (2006), it is recommended that a body be established to help arbitrate disputes between landlord and tenants regarding rent increases, evictions and lease negotiations.

\section{Tax Alleviation Schemes}

It is recommended that the Province reduce the variance in commercial education tax rates between commercial properties and residential properties (Altus Group Limited, 2017).

It is recommended that the City reduce the variance in municipal commercial property tax rates between commercial properties and residential properties (Altus Group Limited, 2017).

It is recommended that the City continue to explore the notion of a property tax class for small businesses and/or low-rise buildings (Pelley, 2017, August 18).

It is recommended that the City continue to use a hard cap of $10 \%$ of the past year's assessment for commercial properties to protect businesses from paying higher taxes to meet increases in municipal spending (City of Toronto, 2018, January 16).

It is recommended that the Province provide municipalities with the power to levy other types of municipal taxes, including local income tax, sales tax, payroll tax, and vehicle and fuel tax, to expand the breadth of municipal revenue sources (Bird \& Slack, 2007).

\section{Vacant Commercial Properties Tax}

It is recommended that the Province consider amending the Municipal Act (2001) to give municipalities the power to add a property tax class for vacant commercial properties. Following which, it is recommended that the City consider introducing a property tax class for vacant 
commercial buildings and a higher tax rate for vacant commercial buildings to motivate their owners to find new tenants. Alternatively, it is recommended that the City introduce a by-law where vacant commercial properties must register with the City and pay an annual fine (City of San Francisco, 2014).

\section{Civic Stewardship}

It is recommended that the City help to build a community coalition of neighbourhood businesses to help assess community needs and assets, set goals, prioritize the community and its original small businesses, and enforce government policies in the Study Area (Great Communities Collaborative, 2007). It is recommended that the City explore the potential of business associations where small business owners can engage in the organization's missions and operations, the delivery of support services and participation in political activities (Sutton, 2010).

It is recommended that the Downtown Yonge Business Improvement Area (DYBIA) extend the boundaries of DYBIA north from Grosvenor Street to Bloor Street to encompass the Study Area where a BIA does not currently exist (City of Toronto, 2016c). Chapter 19 of the City of Toronto Municipal Code governs Business Improvement Areas and Sections 19-2.2 and 19-2.4 details how to expand a BIA. After establishing a steering committee for a BIA expansion and determining community interest with the expansion area, public meeting(s) must be held where more than $50 \%$ of those in attendance need to support moving to the formal BIA expansion request. Following which, a polling process must be conducted where at least $30 \%$ of the ballots mailed or a minimum of 100, whichever is lower, are returned to the City Clerk's Office and more than $50 \%$ of the ballots are in favour of expanding the BIA (City of Toronto, 2017, July 7b). It is recommended that the BIA continue to create campaigns which brand and promote small businesses (DYBIA, 2017-2022). 
It is also recommended that the City evaluate and consider the creation of Business Improvement Districts (BIDs) as seen in the United States. The City should encourage regional coordination of BIAs. Mobility is increasing consumerism and attracting consumer purchasing power requires a regional strategy. A regional strategy would link the downtown to other destinations while giving the BID access to a wider set of resources. This strategy may raise concern for the BIA memberships who are interested in promoting their area. The BIA should expand its scope only after it has become well-established in the area (Gopal-Agge \& Hoyt, 2008).

It is recommended that the City explores a comprehensive small business strategy that considers similar policies in other cities, including, but not limited to the Small Business Plan (2016) in Boston (City of Boston, 2016).

\section{Adjacent Policies}

Housing affordability is a key issue for Toronto. Implementing planning and policy mechanisms to ensure the affordability of the city for residents will also improve conditions for businesses. The City is considering several ideas to help address housing affordability. Inclusionary zoning (City of Toronto, 2018, January 31) and laneway housing (City of Toronto, July 4, 2017) are now among the newest ideas. The City needs to continue to keep the topic of affordability at the forefront of discussions, and to take quick and bold steps. 


\section{CONCLUSION}

Downtown Yonge Street is changing in the face of development pressures. New residents with higher incomes and levels of educational attainment are moving into the neighbourhood. New high-rise luxury condominium buildings are being built. These buildings are raising the property values of existing low-rise buildings. They are being used as the basis for property tax assessments on the principle of highest and best use. Therefore, property taxes are rising for existing low-rise buildings. This is inappropriate considering the heritage nature of most existing low-rise buildings. Property taxes are being passed onto commercial tenants in the form of rents. An influx of new residents with different consumer preferences as well as higher commercial property taxes and rents are contributing factors to the displacement of small businesses in the neighbourhood. Corporate and new entrepreneurial businesses are replacing local businesses, many of which had been otherwise successful for several years.

Local businesses are important. They contribute to the economic and social fabric of the neighbourhood. Local businesses act as gathering places. They cater to the needs of long-term consumers. They generate pedestrian traffic which improves the safety of the neighbourhoods. Overall, local businesses are key elements in the history and character of the neighbourhood.

The City of Toronto has recognized the significance of small businesses in new policies that help to protect the history and character of Downtown Yonge Street as a retail district. Yet, small businesses continue to close their doors. They need further support from the City. Enduring and innovative planning and policy mechanisms are needed to ensure the continued success of small businesses and Downtown Yonge Street. This paper has evaluated options that can promote a healthy balance between small and other businesses in the neighbourhood of Downtown Yonge Street. More research is needed to evaluate their appropriateness for 
Downtown Yonge Street. Small businesses and business associations in Downtown Yonge Street must carry on this conversation with the City and voice their concerns to the City as development applications continue to inundate the neighbourhood. 


\section{REFERENCES}

Altus Group Limited. (2017). Canadian Property Rate Benchmark Report.

Aroma Espresso Bar. (2016). About Us. Retrieved from https://aroma.ca/about/

Bird, R.M. and Slack, E. (2007). "Taxing Land and Property in Emerging Economies: Raising Revenue... and More?" In Ingram, G.K. and Hong, Y. (Eds.), Land Policies and their Outcomes, Cambridge: Lincoln Institute of Land Policy.

Calkins et al. (2014). Permanently Affordable Commercial Space: A Means of Preventing Business Displacement in Neighborhoods Facing Gentrification. Seattle: Evans School of Public Affairs, Community \& Economic Development.

Canada Post. (n.d.). Find a Postal Code. Retrieved from https://www.canadapost.ca/cpo/mc/personal/postalcode/fpc.jsf

CBC News (2017, September 26). Culture hub 401 Richmond could find property tax relief in new tax class. $C B C$ News. Retrieved from http://www.cbc.ca/news/canada/toronto/culture-hub-401-richmond-could-find-propertytax-relief-in-new-tax-class-1.4307193

City of Boston. (2015). Boston Small Business Plan. Retrieved from https://www.cityofboston.gov/images documents/160330\%20Boston\%20Small\%20Busi ness $\% 20$ Full\%20Report $\% 20-\% 20 \mathrm{Web} \% 20(144 \mathrm{dpi})$ tcm3-53060.pdf

City of Phoenix. (2018). Adaptive Reuse Program. Retrieved from https://www.phoenix.gov/pdd/services/permitservices/arp

City of Phoenix. (n.d.). Adaptive Reuse Tiered Eligibility Criteria. https://www.phoenix.gov/pddsite/Documents/TRT/dsd trt pdf 00390.pdf

City of San Francisco Planning Department. (2014). Commission Guide for Formula Retail: Determining Locational Appropriateness and Performance-Based Design Guidelines. Retrieved from http://default.sfplanning.org/publications reports/Formula Retail_Commission_Guide.pd $\underline{\mathrm{f}}$

City of San Francisco. (2014, July 22). Ordinance No. 182-14. Retrieved from http://www.sfbos.org/ftp/uploadedfiles/bdsupvrs/ordinances14/o0182-14.pdf

City of Toronto (2018). Vacant Commercial \& Industrial Unit Tax Rebate Program. Retrieved from https://www.toronto.ca/services-payments/property-taxes-utilities/propertytax/property-tax-rebates-and-relief-programs/vacancy-rebate-program/ 
City of Toronto. (2018, February 12). 2018 Property Tax Rates and Related Matters. Retrieved from http://app.toronto.ca/tmmis/viewAgendaItemHistory.do?item=2018.EX31.1

City of Toronto. (2018, January 31). Inclusionary Zoning. Retrieved from http://app.toronto.ca/tmmis/viewAgendaItemHistory.do?item=2018.PG25.8

City of Toronto. (2018, January 16). Tax Policy Tools to Support Businesses. Retrieved from https://www.toronto.ca/legdocs/mmis/2018/ex/bgrd/backgroundfile-110746.pdf

City of Toronto. (2017, November 9a). By-law 1263-2017. Retrieved from https://www.toronto.ca/legdocs/bylaws/2017/law1263.pdf

City of Toronto. (2017, November 9b). By-law 1264-2017. Retrieved from https://www.toronto.ca/legdocs/bylaws/2017/law1264.pdf

City of Toronto. (2017, July 7a). By-law 770-2017. Retrieved from https://www.toronto.ca/legdocs/bylaws/2017/law0770.pdf

City of Toronto. (2017, July 7b). By-law 785-2017. Retrieved from https://www.toronto.ca/legdocs/bylaws/2017/law0785.pdf

City of Toronto. (2017, July 4). Bridging Laneway Suites to the Toronto and East York District. Retrieved from http://app.toronto.ca/tmmis/viewAgendaItemHistory.do?item=2017.TE25.108

City of Toronto. (2017, April 3). 480-484 Yonge Street and 3 Grosvenor Street - Zoning Amendment Application and Rental Housing Demolition Application - Final Report. Retrieved from http://app.toronto.ca/tmmis/viewAgendaItemHistory.do?item=2017.TE24.5

City of Toronto. (2017, March 28). Creating a Chain Store Retail Strategy for Toronto - by Councillor Mike Layton, seconded by Councillor Kristyn Wong-Tam. Retrieved from http://app.toronto.ca/tmmis/viewAgendaItemHistory.do?item=2017.MM27.36

City of Toronto. (2017, March 27). Alterations to Designated Heritage Properties and Authority to Enter into a Heritage Easement Agreement 480-484 Yonge Street. Retrieved from https://www.toronto.ca/legdocs/mmis/2017/te/bgrd/backgroundfile-102836.pdf

City of Toronto. (2016a). Historic Yonge Street Heritage Conservation District Plan. Retrieved from https://www.toronto.ca/legdocs/mmis/2016/te/bgrd/backgroundfile-88803.pdf.

City of Toronto. (2016b). Official Plan. Retrieved from https://www.toronto.ca/city-government/planning-development/official-planguidelines/official-plan/

City of Toronto. (2016c). 82 Business Improvement Areas. Retrieved from 
https://www.toronto.ca/wp-content/uploads/2017/07/97ab-map-bias-in-toronto.pdf

City of Toronto. (2016, March 10). By-law 235-2016. Retrieved from https://www.toronto.ca/legdocs/bylaws/2016/law0235.pdf

City of Toronto. (2015). 2015 Business Connect: Connecting Toronto's business community to select Municipal, Provincial and Federal assistance programs, services and incentives. Retrieved from https://www.toronto.ca/wp-content/uploads/2017/07/8908BusinessConnect2015 web.pdf

City of Toronto (2014, February 20). By-law 139-2014. Retrieved from https://www.toronto.ca/legdocs/bylaws/2014/law0139.pdf

City of Toronto. (2013a). North Downtown Yonge Toronto Urban Design Guidelines. Retrieved from https://www.toronto.ca/legdocs/mmis/2013/te/bgrd/backgroundfile-61187.pdf

City of Toronto. (2013b). Zoning By-law 569-2013.

City of Toronto. (2013c). Tall Building Design Guidelines. Retrieved from https://www.toronto.ca/legdocs/mmis/2013/pg/bgrd/backgroundfile-57177.pdf

City of Toronto, (2013, September 23). 501 to 521 Yonge Street; 6 to 8 Alexander Street and 23 Maitland Street - Zoning Amendment Application - Final Report. Retrieved from https://www.toronto.ca/legdocs/mmis/2013/te/bgrd/backgroundfile-62105.pdf

City of Toronto. (2009, October 19). 606-618 Yonge Street, 5-9 Joseph Street, 11-19 and 25 St. Nicholas Street - Rezoning. Retrieved from http://app.toronto.ca/tmmis/viewAgendaItemHistory.do?item=2009.TE29.8

City of Toronto. (1998-2018a). Application Information Centre. Retrieved from http://app.toronto.ca/DevelopmentApplications/mapSearchSetup.do?action=init

City of Toronto. (1998-2018b). Glossary of Terms. Retrieved from https://www.toronto.ca/city-government/planning-development/application-formsfees/building-toronto-together-a-development-guide/glossary-of-terms/

City of Toronto. (1998-2018c). City of Toronto's Heritage Property Search. Retrieved from http://app.toronto.ca/HeritagePreservation/setup.do?action=init

City of Toronto. (1998-2018d). Small Business Centres. Retrieved from https://www.toronto.ca/business-economy/business-start-ups/small-business-centres/

City of Toronto. (1998-2018e). Business Expansion and Location Assistance. Retrieved from 
https://www.toronto.ca/business-economy/business-operation-growth/businessexpansion-and-location-assistance/

City of Toronto. (1986). Zoning By-law 438-86.

City of Toronto Archives. (n.d.). City of Toronto Archives Database. Retrieved from https://gencat4.eloquentsystems.com/webcat/request/DoMenuRequest?SystemName $=$ City + of + Toronto + Archives $\&$ UserName $=$ wa + public $\&$ Password $=\&$ TemplateProcessID $=6000 \_1580 \_11104 \& b C a c h a$ $\underline{\text { ble }=1 \& \text { MenuName }=\text { City }+ \text { of }+ \text { Toronto }+ \text { Archives } \& \text { eloquentref }=\text { toronto }}$

Deener, A. (2007). Commerce as the Structure and Symbol of Neighborhood Life: Reshaping the Meaning of Community in Venice, California. City and Community, 6(4), 291-314.

Doan, P.L. \& Higgins, H. (2011). The Demise of Queer Space? Resurgent Gentrification and the Assimilation of LBGT Neighborhoods. Journal of Planning Education and Research, $31(1), 6-25$.

Downtown Yonge Business Improvement Area. (n.d.). About. Retrieved from http://www.downtownyonge.com/about/

DYBIA. (2017-2022). Living Yonge: The Path to Prosperity in our World-Leading Downtown Neighbourhood: Strategic Plan. Retrieved from http://www.downtownyonge.com/files/Downtown $\% 20$ Yonge $\% 20 \mathrm{BIA} \% 20$ \%20Strategic $\% 20$ Plan $\% 20-\% 20 \mathrm{Web} \% 20 \mathrm{PDF} . \mathrm{PDF}$

Freeman, L. (2005). Displacement or Succession?: Residential Mobility in Gentrifying Neighborhoods. Urban Affairs Review, 40(4), 463-491.

Glass, R. (1964). Introduction: Aspects of Change. In Centre for Urban Studies (Ed.), Aspects of Change (pp. xiii-xlii). London: MacKibbon and Kee.

Godsil, R. D. (2013). The Gentrification Trigger: Autonomy, Mobility, and Affirmatively Furthering Fair Housing. Brooklyn Law Review, 78(2), 319-338.

Goodyear, S. (2016, April 5). Malls of America: Can San Francisco's solution to protect momand-pop shops help preserve the character of city neighborhoods everywhere? Daily News. Retrieved from http://interactive.nydailynews.com/2016/04/save-mom-pop-shopsgentrification/\#page1

Google Maps Street View. (2017, August). 480 Yonge Street. Retrieved from https://www.google.ca/maps/place/480+Yonge+St,+Toronto,+ON+M4Y+1X5/@43.6626 349,-79.3835516,3a,75y,232.19h,90t/data=!3m7!1e1!3m5!1 spdka20MVGzw72cQGs392A!2e0!6s\%2F\%2Fgeo2.ggpht.com\%2Fcbk\%3Fpanoid\%3Dpdka20MVGzw72cQGs392A\%26output\%3Dthumbnail\%26cb client\%3Dsearch.TACTILE.gps\%26 thumb $\% 3 \mathrm{D} 2 \% 26 \mathrm{w} \% 3 \mathrm{D} 86 \% 26 \mathrm{~h} \% 3 \mathrm{D} 86 \% 26 \mathrm{yaw} \% 3 \mathrm{D} 232.18575 \% 26 \mathrm{pitch} \% 3 \mathrm{D} 0 \% 26$ thu 
mbfov\%3D100!7i13312!8i6656!4m5!3m4!1s0x882b34b466457cb9:0x62a277ccdbeabb2 e! $8 \mathrm{~m} 2 ! 3 \mathrm{~d} 43.6625423 ! 4 \mathrm{~d}-79.3837402$

Google Maps Street View. (2017, August). 5 St. Joseph Street. Retrieved from https://www.google.ca/maps/place/5+St+Joseph+St,+Toronto,+ON+M4Y+0B6/@43.665 9329,79.3855651,3a,75y,170.62h,90t/data=!3m7!1e1!3m5!1sai5nnriapa4KQjlav3iZNA! 2e0!6s\%2F\%2Fgeo1.ggpht.com\%2Fcbk\%3Fpanoid\%3Dai5nnriapa4KQjlav3iZNA\%26o utput $\% 3$ Dthumbnail $\% 26 \mathrm{cb}$ client $\% 3$ Dsearch.TACTILE.gps $\% 26$ thumb $\% 3 \mathrm{D} 2 \% 26 \mathrm{w} \% 3 \mathrm{D}$ 86\%26h\%3D86\%26yaw\%3D170.61728\%26pitch\%3D0\%26thumbfov\%3D100!7i13312! $\underline{8 \mathrm{i} 6656 ! 4 \mathrm{~m} 5 ! 3 \mathrm{~m} 4 ! 1 \mathrm{~s} 0 \times 882 \mathrm{~b} 34 \mathrm{~b} 3 \mathrm{~cd} 1 \mathrm{~b} 5 \mathrm{~d} 35: 0 \times 56 \mathrm{~d} 995 \mathrm{a} 3952531 \mathrm{f} 3 ! 8 \mathrm{~m} 2 ! 3 \mathrm{~d} 43.6657528 ! 4 \mathrm{~d}}$ $-79.3855792$

Google Maps Street View. (2015, September). 501 Yonge Street. Retrieved from https://www.google.ca/maps/place/501+Yonge+St,+Toronto,+ON+M4Y+1Y4/@43.6632 699,79.3839427,3a,75y,38.42h,90t/data=!3m7!1e1!3m5!1smYz02W vcSczs1vW85yNN g!2e0!5s20150901T000000!7i13312!8i6656!4m5!3m4!1s0x882b34b47be59947:0x99864 a319a9a05a6!8m2!3d43.6631962!4d-79.3835684

Google Maps Street View (2017, August). 501 Yonge Street. Retrieved from https://www.google.ca/maps/place/501+Yonge+St,+Toronto,+ON+M4Y+1Y4/@43.6632 733,79.3839405,3a,75y,38.42h,90t/data=!3m6!1e1!3m4!1s*211m2*211y9811994162934 $159687 * 212 \mathrm{y} 11062611111589840294 * 213 \mathrm{~m} 2 * 211 \mathrm{y} 9811889527785780377 * 212 \mathrm{y} 29584$ $45028497682872 * 215 \mathrm{~m} 2 * 211 \times 436631962 * 212 \times 3501131612$ ! $2 \mathrm{e} 0$ ! $7 \mathrm{i} 13312$ ! $8 \mathrm{i} 6656 ! 4 \mathrm{~m} 5$ ! $\underline{3 \mathrm{~m} 4 \text { ! 1s0x882b34b47be59947:0x99864a319a9a05a6!8m2!3d43.6631962!4d-79.3835684 }}$

Google Maps Street View. (2015, May). 501 Yonge Street. Retrieved from https://www.google.ca/maps/place/501+Yonge+St,+Toronto,+ON+M4Y+1Y4/@433.6633 346,79.3838507,3a,75y,26.05h,74.74t/data=!3m7!1e1!3m5!1ssxi14 BtNnLaAV7uUcesI $\mathrm{g}$ !2e0!5s20150901T000000!7i13312!8i6656!4m5!3m4!1s0x882b34b47be59947:0x99864 a319a9a05a6! $8 \mathrm{~m} 2 ! 3 \mathrm{~d} 43.6631962 ! 4 \mathrm{~d}-79.3835684$

Google Maps Street View. (2009, July). 606 Yonge Street. Retrieved from https://www.google.ca/maps/place/606+Yonge+St,+Toronto,+ON+M4Y+1Z3/@43.6656 349,79.384883,3a,75y,255.01h,90t/data=!3m7!1e1!3m5!1s6EipQQK 5dz9XaF9amJ9CQ !2e0!5s20090701T000000!7i13312!8i6656!4m5!3m4!1s0x882b34b3ce46b259:0xcc61d7 $\underline{31 \mathrm{a} 7 \mathrm{dd} 60 \mathrm{e} 3 ! 8 \mathrm{~m} 2 ! 3 \mathrm{~d} 43.6656578 ! 4 \mathrm{~d}-79.3851645}$

Gopal-Agge, D. \& Hoyt L. (2008). The BID Model in Canada and the United States: The RetailRevitalization Nexus. In Morcol, G., Hoyt, L., Meek, J.W. \& Zimmermann, U. (Ed.), Research, Theories, and Controversies (pp. 139-158). Boca Raton, FL: CRC Press.

Gratz, R. \& Mintz, N. (1998). Cities Back from the Edge: New Life for Downtown. New York: John Wiley.

Great Communities. (2007). Preventing Displacement Policy Fact Sheet. Retrieved from 
http://www.greatcommunities.org/wpcontent/uploads/pdf/2007\%2011\%20Preventing\%2 0Displacement $\% 20$ Policy $\% 20$ Fact $\% 20$ Sheet.pdf

Harris, D. (2010). Place, race, and story: Essays on the past and future of historic preservation. The Journal of American History, 97, 482-483.

Hastings, T. \& Reynolds, J. (n.d.). Do small retailers really generate social value? Retrieved on March 312018 from https://www.sbs.ox.ac.uk/faculty-research/insightsresearch/marketing/do-small-retailers-really-generate-social-value

Hill, K. \& Pozzo, C. (2005). Managing Neighborhood Change: Best Practices for Communities Undergoing Gentrification. Washington: NeighborWorks America.

Imrie, R., Thomas, H. \& Marshall, T. (1995). Business organisations, local dependence and the politics of urban renewal in Britain. Urban Studies, 32(1), 31-48.

Kiviat, B. (2008). Gentrification: Not Ousting the Poor? Time Magazine, June 29.

Klingbeil, C. (2017, June 6). Rising commercial property taxes put small-business owners in a bind. Globe and Mail. Retrieved from

https://www.theglobeandmail.com/report-on-business/small-business/sb-money/risingcommercial-property-taxes-put-small-business-owners-in-a-bind/article35152561/

Klingbeil, C. (2017, October 31). Toronto eyes new tax class that could spell relief for small businesses. Globe and Mail. Retrieved from https://www.theglobeandmail.com/report-on-business/small-business/sbmanaging/toronto-eyes-new-tax-class-that-could-spell-relief-for-smallbusinesses/article36777477/

Jacobs, J. (1961). The Death and Life of Great American Cities. New York: Vintage Books.

LaVecchia, O. \& Mitchell, S. (2016). Affordable Space: How Rising Commercial Rents Are Threatening Independent Businesses, and What Cities Are Doing About It. Institute for Local Self-Reliance.

Lees, L., Slater, T., \& Wyly, E. K. (2008). Gentrification. New York: Routledge/Taylor \& Francis Group.

Levy, D. K., Comey, J., Padilla, S. (2006). In the face of gentrification: Case studies of local efforts to mitigate displacement. Washington, DC: The Urban Institute, Metropolitan Housing and Communities Policy Center, The Urban Institute.

Ley, D. (1994). Gentrification and the politics of the new middle class. Environment and Planning D: Society and Space, 12, 53-74.

Lloyd, R. (2006). New-Bohemia: Art and Commerce in the Post-industrial City. New York: 


\section{Routledge.}

Ma, M. (2018, January 13). This is how the City of Vancouver can save local businesses. Medium. Retrieved from https://medium.com/@melodyma/this-is-how-the-city-can-savelocal-businesses-in-vancouver-82088971bd7a

Maeckelbergh, M. (2012). Mobilizing to stay put: Housing struggles in New York City. International Journal of Urban and Regional Research.

McLean, H. \& Rankin, K.N. (2014). Governing the Commercial Streets of the City: New Terrains of Disinvestment and Gentrification in Toronto's Inner Suburbs. Antipode, 4l(1), p. 216-233.

Miles et al. (2007). Real Estate Development Principles and Process (4 ${ }^{\text {th }}$ ed.). Washington: The Urban Land Institute.

Mitchell, D. (2017, August 16). Toronto councillor calls for property tax reform for Yonge St. businesses. Global News. Retrieved from https://globalnews.ca/news/3675350/torontocouncillor-calls-for-property-tax-reform-for-yonge-st-businesses/

Mitchell, S. (2006). Big-box swindle: The true cost of mega-retailers and the fight for America's independent business. Boston, MA: Beacon Press.

Oldenburg, R. (1996-97). Our Vanishing “Third Places”. Planning Commissioners Journal, 25, p. 6-10.

Ontario. (2018). Rent Increase Guideline. Retrieved from https://www.ontario.ca/page/rent-increase-guideline

Ontario. (2006). Residential Tenancies Act, S.O. 2006, c. 17.

Ontario. (1990). Commercial Tenancies Act., R.S.O. 1990, c. L.7

Ontario. (1990). Ontario Heritage Act. R.S.O. 1990.

Ontario. (1990). Planning Act, R.S.O 1990, c. P.13.

Owens, A. (2012). Neighborhoods on the Rise: A Typology of Neighborhood Experiencing Socioeconomic Ascent. City \& Community, 11(4), 245-269.

Parkdale Community Land Trust. (n.d.). About. Retrieved from http://www.pnlt.ca/about/

Pelley, L. (2017, August 18). Renewed hope of avoiding 'death by property taxes' for Yonge Street businesses hit by $100 \%$ hike. $C B C$ News. Retrieved from http://www.cbc.ca/news/canada/toronto/yonge-tax-meeting-1.4252524 
Queen's University. (1998). Queen's Heritage University Study: Appendix B: Options for Heritage Protection. Kingston: Queen's University.

Ritter, B. (2009). "Creation and Preservation of Affordable Commercial Space in Seattle's Neighborhood Business Districts”. Degree Project, Evans School of Public Affairs. University of Washington.

Rose, K. (2001). "Beyond Gentrification: Tools for Equitable Development," Shelterforce. Accessed March 31, 2018. http://www.nhi.org/online/issues/117/Rose.html.

Seidman, K. F. (2005). Economic Development Finance. Thousand Oaks, CA: Sage Publications.

Shaw, S., Bagwell, S. \& Karmowska, J. (2014). Ethnoscapes as Spectacle: Reimaging Multicultural

Districts as New Destinations for Leisure and Tourism Consumption. Urban Studies, 41(1), p. $1983-2000$.

Shiflet, K. (2006). Promoting Equitable Development: Tackling Commercial Gentrification in Historic Districts. School of Architecture, Planning and Preservation; Department of Historic Preservation. University of Maryland.

Skira, Edward. (April 6, 2011). Lanterra Developments Purchases 501 Yonge Street For \$38.5 Million - Future Condos Coming. Urban Toronto. Retrieved from http://urbantoronto.ca/news/2011/04/lanterra-developments-purchases-501-yonge-street385-million-future-condos-coming

Smith, N. (1987). Gentrification and the Rent Gap. Annals of the Association of American Geographers, 77(3), 462-465.

Statistics Canada. (2016). Classification of highest certificate, diploma, or degree. Retrieved from http://www23.statcan.gc.ca/imdb/p3VD.pl?Function=getVD\&TVD=117391\&CVD=117 $\underline{394 \& \mathrm{CPV}=2.4 .1 \& \mathrm{CST}=20062011 \& \mathrm{CLV}=5 \& \mathrm{MLV}=5}$

Statistics Canada. (2017a). Census Profile, 2016 Census: 35204583 [Dissemination area], Ontario. Retrieved from http://www12.statcan.gc.ca/census-recensement/2016/dp$\mathrm{pd} /$ prof/details/page.cfm?Lang $=\mathrm{E} \& \mathrm{Geo} 1=\mathrm{DA} \&$ Code $1=35204583 \& \mathrm{Geo} 2=\mathrm{CSD} \& \mathrm{Code} 2=$ $\underline{3520005 \& D a t a}=$ Count $\&$ SearchText $=35204583 \&$ SearchType $=$ Begins $\&$ SearchPR $=01 \& B$ $1=\mathrm{All} \& \mathrm{TABID}=3$

Statistics Canada. (2017b). Census Profile, 2016 Census: 35204589 [Dissemination area], Ontario. Retrieved from http://www12.statcan.gc.ca/census-recensement/2016/dp$\mathrm{pd} /$ prof $/$ details/page.cfm?Lang $=$ E\&Geo $1=$ DA\&Code $1=35204589 \& G e 02=$ CSD $\&$ Code $2=$ $3520005 \&$ Data $=$ Count $\&$ SearchText $=35204589 \&$ Search Type $=$ Begins $\&$ SearchPR $=01 \& B$ $\underline{1=\mathrm{All} \& \mathrm{TABID}=3}$ 
Statistics Canada. (2017c). Census Profile, 2016 Census: 35204590 [Dissemination area], Ontario. Retrieved from http://www12.statcan.gc.ca/census-recensement/2016/dp$\mathrm{pd} /$ prof/details/page.cfm?Lang $=$ E\&Geo $1=$ DA\&Code $1=35204590 \&$ Geo $2=$ CSD\&Code $2=$ $\underline{3520005 \& D a t a}=$ Count $\&$ SearchText $=35204590 \&$ SearchType $=$ Begins $\&$ SearchPR $=01 \& B$ $1=\mathrm{All} \& \mathrm{TABID}=3$

Statistics Canada. (2017d). Census Profile, 2016 Census: 35204591 [Dissemination area], Ontario. Retrieved from http:/www12.statcan.gc.ca/census-recensement/2016/dp$\mathrm{pd} /$ prof/details/page.cfm?Lang $=\mathrm{E} \& \mathrm{Geo} 1=\mathrm{DA} \&$ Code $1=35204591 \& \mathrm{Geo} 2=\mathrm{CSD} \& \mathrm{Code} 2=$ $3520005 \&$ Data $=$ Count $\&$ SearchText $=35204591 \&$ SearchType $=$ Begins $\&$ SearchPR $=01 \& B$ $\underline{1=\mathrm{All} \& \mathrm{TABID}=3}$

Statistics Canada. (2017e). Census Profile, 2016 Census: 35204592 [Dissemination area], Ontario. Retrieved from http://www12.statcan.gc.ca/census-recensement/2016/dp$\mathrm{pd} / \mathrm{prof} /$ details/page.cfm?Lang $=\mathrm{E} \& \mathrm{Geo} 1=\mathrm{DA} \&$ Code $1=35204592 \& \mathrm{Geo} 2=\mathrm{CSD} \& \mathrm{Code} 2=$ $\underline{3520005 \& \text { Data }=\text { Count } \& \text { SearchText }=35204592 \& \text { SearchType }=\text { Begins } \& \text { SearchPR }=01 \& B}$ $1=\mathrm{All} \& \mathrm{TABID}=3$

Statistics Canada. (2017f). Census Profile, 2016 Census: 35204593 [Dissemination area], Ontario. Retrieved from http://www12.statcan.gc.ca/census-recensement/2016/dp$\mathrm{pd} /$ prof/details/page.cfm?Lang $=$ E\&Geo $1=$ DA\&Code $1=35204593 \&$ Geo $2=$ CSD $\&$ Code $2=$ $3520005 \&$ Data $=$ Count $\&$ SearchText $=35204593 \&$ SearchType $=$ Begins $\&$ SearchPR $=01 \& B$ $\underline{1=\mathrm{All} \& \mathrm{TABID}=3}$

Statistics Canada. (2017g). Census Profile, 2016 Census: 35204594 [Dissemination area], Ontario. Retrieved from http://www12.statcan.gc.ca/census-recensement/2016/dp$\mathrm{pd} /$ prof/details/page.cfm?Lang $=$ E\&Geo $1=$ DA\&Code $1=35204594 \& G e o 2=$ CSD\&Code $2=$ $\underline{3520005 \& D a t a}=$ Count $\&$ SearchText $=35204594 \&$ SearchType $=$ Begins $\&$ SearchPR $=01 \& B$ $1=\mathrm{A} 11 \& \mathrm{TABID}=3$

Statistics Canada. (2017h). Census Profile, 2016 Census: 35204595 [Dissemination area], Ontario. Retrieved from http://www12.statcan.gc.ca/census-recensement/2016/dp$\mathrm{pd} /$ prof/details/page.cfm?Lang $=\mathrm{E} \&$ Geo $1=\mathrm{DA} \&$ Code $1=35204595 \& \mathrm{Geo} 2=\mathrm{CSD} \& \mathrm{Code} 2=$ $3520005 \&$ Data $=$ Count $\&$ SearchText $=35204595 \&$ SearchType $=$ Begins $\&$ Search $P R=01 \& B$ $\underline{1=\mathrm{A} 11 \& \mathrm{TABID}=3}$

Statistics Canada. (2017i). Census Profile, 2016 Census: 35204596 [Dissemination area], Ontario. Retrieved from http://www12.statcan.gc.ca/census-recensement/2016/dp$\mathrm{pd} /$ prof $/$ details/page.cfm?Lang $=$ E $\&$ Geo $1=$ DA\&Code $1=35204596 \&$ Geo $2=$ CSD $\&$ Code $2=$ $\underline{3520005 \& \text { Data }=\text { Count } \& \text { SearchText }=35204596 \& \text { SearchType }=\text { Begins } \& \text { SearchPR }=01 \& B}$ $1=\mathrm{All} \& \mathrm{TABID}=3$

Statistics Canada. (2017j). Census Profile, 2016 Census: 35204597 [Dissemination area], Ontario. Retrieved from http:/www12.statcan.gc.ca/census-recensement/2016/dp$\mathrm{pd} /$ prof/details/page.cfm?Lang $=$ E\&Geo1 $=$ DA\&Code $1=35204597 \&$ Geo $2=$ CSD\&Code $2=$ 
$3520005 \&$ Data $=$ Count $\&$ SearchText $=35204597 \&$ SearchType $=$ Begins $\&$ SearchPR $=01 \& B$ $\underline{1=\mathrm{A} 11 \& \mathrm{TABID}=3}$

Statistics Canada. (2017k). Census Profile, 2016 Census: 35204598 [Dissemination area], Ontario. Retrieved from http://www12.statcan.gc.ca/census-recensement/2016/dp$\mathrm{pd} /$ prof $/$ details/page.cfm?Lang $=\mathrm{E} \& \mathrm{Geo} 1=\mathrm{DA} \&$ Code $1=35204598 \& \mathrm{Geo} 2=\mathrm{CSD} \& \mathrm{Code} 2=$ $\underline{3520005 \& \text { Data }=\text { Count } \& \text { SearchText }=35204598 \& \text { SearchType }=\text { Begins } \& \text { SearchPR }=01 \& B}$ $\underline{1=\mathrm{All} \& \mathrm{TABID}=3}$

Statistics Canada. (20171). Census Profile, 2016 Census: 35204599 [Dissemination area], Ontario. Retrieved from http://www12.statcan.gc.ca/census-recensement/2016/dp$\mathrm{pd} /$ prof $/$ details/page.cfm?Lang $=\mathrm{E} \&$ Geo $1=\mathrm{DA} \&$ Code $1=35204599 \& \mathrm{Geo} 2=\mathrm{CSD} \& \mathrm{Code} 2=$ $\underline{3520005 \& \text { Data }=\text { Count } \& \text { SearchText }=35204599 \& \text { SearchType }=\text { Begins } \& \text { SearchPR }=01 \& \mathrm{~B}}$ $\underline{1=\mathrm{All} \& \mathrm{TABID}=3}$

Statistics Canada. (2017m). Census Profile, 2016 Census: 35204600 [Dissemination area], Ontario. Retrieved from http://www12.statcan.gc.ca/census-recensement/2016/dp$\mathrm{pd} /$ prof/details/page.cfm?Lang $=$ E\&Geo1 $=$ DA\&Code $1=35204600 \& G e o 2=$ CSD\&Code $2=$ $\underline{3520005 \& D a t a}=$ Count $\&$ SearchText $=35204600 \&$ SearchType $=$ Begins $\&$ SearchPR $=01 \& B$ $\underline{1=\mathrm{A} 11 \& \mathrm{TABID}=3}$

Statistics Canada. (2017n). Census Profile, 2016 Census: 35204601 [Dissemination area], Ontario. Retrieved from http://www12.statcan.gc.ca/census-recensement/2016/dp$\mathrm{pd} /$ prof/details/page.cfm?Lang $=\mathrm{E} \& \mathrm{Geo} 1=\mathrm{DA} \&$ Code $1=35204601 \& \mathrm{Geo} 2=\mathrm{CSD} \& \mathrm{Code} 2=$ $\underline{3520005 \& D a t a}=$ Count $\&$ SearchText $=35204601 \&$ SearchType $=$ Begins $\&$ SearchPR $=01 \& B$ $\underline{1=\mathrm{All} \& \mathrm{TABID}=3}$

Statistics Canada. (2017o). Census Profile, 2016 Census: 35204602 [Dissemination area], Ontario. Retrieved from http://www12.statcan.gc.ca/census-recensement/2016/dp$\mathrm{pd} /$ prof $/$ details/page.cfm?Lang $=\mathrm{E} \& \mathrm{Geo} 1=\mathrm{DA} \&$ Code $1=35204602 \& \mathrm{Geo} 2=\mathrm{CSD} \& \mathrm{Code} 2=$ $\underline{3520005 \& D a t a}=$ Count $\&$ SearchText $=35204602 \&$ SearchType $=$ Begins $\&$ SearchPR $=01 \& B$ $\underline{1=\mathrm{All} \& \mathrm{TABID}=3}$

Statistics Canada. (2017p). Census Profile, 2016 Census: 35204603 [Dissemination area], Ontario. Retrieved from http://www12.statcan.gc.ca/census-recensement/2016/dp$\mathrm{pd} /$ prof $/$ details/page.cfm?Lang $=$ E\&Geo $1=$ DA\&Code $1=35204603 \& G e o 2=$ CSD $\&$ Code $2=$ $\underline{3520005 \& \text { Data }=\text { Count } \& \text { SearchText }=35204603 \& \text { SearchType }=\text { Begins } \& \text { SearchPR }=01 \& B}$ $\underline{1=\mathrm{A} 11 \& \mathrm{TABID}=3}$

Statistics Canada. (2017q). Census Profile, 2016 Census: 35204618 [Dissemination area], Ontario. Retrieved from http://www12.statcan.gc.ca/census-recensement/2016/dp$\mathrm{pd} /$ prof/details/page.cfm?Lang $=\mathrm{E} \& \mathrm{Geo} 1=\mathrm{DA} \&$ Code $1=35204618 \& \mathrm{Geo} 2=\mathrm{CSD} \& \mathrm{Code} 2=$ $\underline{3520005 \& D a t a}=$ Count $\&$ SearchText $=35204618 \&$ SearchType $=$ Begins $\&$ SearchPR $=01 \& B$ $\underline{1=\mathrm{All} \& \mathrm{TABID}=3}$

Statistics Canada. (2017r). Census Profile, 2016 Census: 35204620 [Dissemination area], 
Ontario. Retrieved from http://www12.statcan.gc.ca/census-recensement/2016/dp$\mathrm{pd} /$ prof $/$ details/page.cfm?Lang $=$ E \&Geo1 $=$ DA\&Code $1=35204618 \&$ Geo $2=$ CSD $\&$ Code $2=$

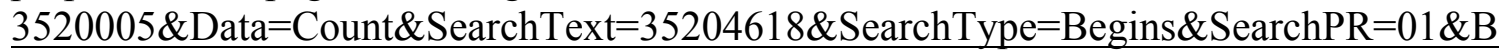
$1=\mathrm{All} \& \mathrm{TABID}=3$

Statistics Canada. (2017s). Census Profile, 2016 Census: 35204621 [Dissemination area], Ontario. Retrieved from http://www12.statcan.gc.ca/census-recensement/2016/dp$\mathrm{pd} /$ prof/details/page.cfm?Lang $=$ E\&Geo1 $=$ DA\&Code $1=35204621 \&$ Geo $2=$ CSD\&Code $2=$ $3520005 \&$ Data $=$ Count $\&$ SearchText $=35204621 \&$ SearchType $=$ Begins $\&$ SearchPR $=01 \& B$ $\underline{1=\mathrm{All} \& \mathrm{TABID}=3}$

Statistics Canada. (2017t). Census Profile, 2016 Census: 35204622 [Dissemination area], Ontario. Retrieved from http://www12.statcan.gc.ca/census-recensement/2016/dp$\mathrm{pd} /$ prof $/$ details/page.cfm?Lang $=\mathrm{E} \& \mathrm{Geo} 1=\mathrm{DA} \& \mathrm{Code} 1=35204622 \& \mathrm{Geo} 2=\mathrm{CSD} \& \mathrm{Code} 2=$ $\underline{3520005 \& D a t a}=$ Count $\&$ SearchText $=35204622 \&$ SearchType $=$ Begins $\&$ SearchPR $=01 \& B$ $1=\mathrm{A} 11 \& \mathrm{TABID}=3$

Statistics Canada. (2017u). Census Profile, 2016 Census: 35204623 [Dissemination area], Ontario. Retrieved from http://www12.statcan.gc.ca/census-recensement/2016/dp$\mathrm{pd} /$ prof/details/page.cfm?Lang $=\mathrm{E} \& \mathrm{Geo} 1=\mathrm{DA} \&$ Code $1=35204623 \& \mathrm{Geo} 2=\mathrm{CSD} \& \mathrm{Code} 2=$ $3520005 \&$ Data $=$ Count $\&$ SearchText $=35204623 \&$ SearchType $=$ Begins $\&$ SearchPR $=01 \& B$ $\underline{1=\mathrm{A} 11 \& \mathrm{TABID}=3}$

Statistics Canada. (2017v). Census Profile, 2016 Census: 35204624 [Dissemination area], Ontario. Retrieved from http://www12.statcan.gc.ca/census-recensement/2016/dp$\mathrm{pd} /$ prof $/$ details/page.cfm?Lang $=\mathrm{E} \& \mathrm{Geo} 1=\mathrm{DA} \& \mathrm{Code} 1=35204624 \& \mathrm{Geo} 2=\mathrm{CSD} \& \mathrm{Code} 2=$ $\underline{3520005 \& D a t a}=$ Count $\&$ SearchText $=35204624 \&$ SearchType $=$ Begins $\&$ SearchPR $=01 \& B$ $1=\mathrm{All} \& \mathrm{TABID}=3$

Statistics Canada. (2017w). Census Profile, 2016 Census: 35204882 [Dissemination area], Ontario. Retrieved from http://www12.statcan.gc.ca/census-recensement/2016/dp$\mathrm{pd} /$ prof/details/page.cfm?Lang $=$ E\&Geo $1=$ DA\&Code $1=35204882 \&$ Geo $2=$ CSD\&Code $2=$ $3520005 \&$ Data $=$ Count $\&$ SearchText $=35204882 \&$ SearchType $=$ Begins $\&$ SearchPR $=01 \& B$ $\underline{1=\mathrm{A} 11 \& \mathrm{TABID}=3}$

Statistics Canada. (2017x). Census Profile, 2016 Census: 35204883 [Dissemination area], Ontario. Retrieved from http://www12.statcan.gc.ca/census-recensement/2016/dp$\mathrm{pd} /$ prof/details/page.cfm?Lang $=$ E\&Geo $1=$ DA\&Code $1=35204883 \&$ Geo $2=$ CSD\&Code $2=$ $\underline{3520005 \& D a t a}=$ Count $\&$ SearchText $=35204883 \&$ SearchType $=$ Begins $\&$ SearchPR $=01 \& B$ $\underline{1=\mathrm{All} \& \mathrm{TABID}=3}$

Statistics Canada. (2017y). Census Profile, 2016 Census: 35204901 [Dissemination area], Ontario. Retrieved from http://www12.statcan.gc.ca/census-recensement/2016/dp$\mathrm{pd} /$ prof/details/page.cfm?Lang $=\mathrm{E} \& \mathrm{Geo} 1=\mathrm{DA} \& \mathrm{Code} 1=35204901 \& \mathrm{Geo} 2=\mathrm{CSD} \& \mathrm{Code} 2=$ $3520005 \&$ Data $=$ Count $\&$ SearchText $=35204901 \&$ SearchType $=$ Begins $\&$ SearchPR $=01 \& B$ $\underline{1=\mathrm{All} \& \mathrm{TABID}=3}$ 
Statistics Canada. (2017z). Census Profile, 2016 Census: 35204902 [Dissemination area], Ontario. Retrieved from http://www12.statcan.gc.ca/census-recensement/2016/dp$\mathrm{pd} /$ prof/details/page.cfm?Lang $=$ E\&Geo $1=$ DA\&Code $1=35204902 \&$ Geo $2=$ CSD $\&$ Code $2=$ $3520005 \&$ Data $=$ Count $\&$ SearchText $=35204902 \&$ SearchType $=$ Begins $\&$ SearchPR $=01 \& B$ $1=\mathrm{All} \& \mathrm{TABID}=3$

Statistics Canada (2017, November 29). Education in Canada: Key results from the 2016 Census. The Daily. Retrieved from https://www.statcan.gc.ca/daily-quotidien/171129/dq171129a-eng.htm

Statistics Canada. (2007a). Census Profile, 2006 Census: 5350062.01 (CT). Retrieved from http://www12.statcan.ca/census-recensement/2006/dp-pd/prof/92597/P3.cfm?Lang=E\&CTCODE=6097\&CATYPE $=$ CMA

Statistics Canada. (2007b). Census Profile, 2006 Census: 5350062.02 (CT). Retrieved from http://www12.statcan.ca/census-recensement/2006/dp-pd/prof/92597/P3.cfm?Lang=E\&CTCODE $=6098 \& C A C O D E=535 \& P R C O D E=35 \& P C=m 4 y 1 x 9$

Statistics Canada. (2007c). Census Profile, 2006 Census: 5350063.01 (CT). Retrieved from http://www12.statcan.ca/census-recensement/2006/dp-pd/prof/92597/P3.cfm?Lang=E\&CTCODE=3987\&CATYPE=CMA

Sutton, S.A. (2010). Rethinking commercial revitalization: A neighborhood small business perspective. Economic Development Quarterly, 24, p. 352-371.

Toronto Business Development Centre. (2015). What We Do. Retrieved from http://tbdc.com.

West Harlem Community Benefits Agreement. (2009, May 18). Retrieved from https:/gca.columbia.edu/sites/default/files/2016-11/CBAAgreement.pdf

Williams, T. L. \& Needham, C. R. (2016). Gentrification's Influence on the Small Business Owners of Harlem, New York. SAGE Open, 6(4).

Wyly, E. \& Hammel, D. (2005). Mapping neoliberal American urbanism, in: R. Atkinson \& G. Bridge (Eds) Gentrification in a Global Context: The New Urban Colonialism, pp. 18-38 (London: Routledge).

Zukin, S. et al. (2009). New Retail Capital and Neighborhood Change: Boutiques and Gentrification in New York City. City \& Community, 8, 47-64.

Zukin, S. (2010). Naked City: The Death and Life of Authentic Urban Places. New York: Oxford University Press. 